\title{
Hemodiafiltration : the simultaneous application of hemodialysis and hemofiltration
}

Citation for published version (APA):

van Geelen, J. A. C. A. (1983). Hemodiafiltration : the simultaneous application of hemodialysis and hemofiltration. [Doctoral Thesis, Maastricht University]. Rijksuniversiteit Limburg. https://doi.org/10.26481/dis.19831202jg

Document status and date:

Published: 01/01/1983

DOI:

10.26481/dis.19831202jg

Document Version:

Publisher's PDF, also known as Version of record

\section{Please check the document version of this publication:}

- A submitted manuscript is the version of the article upon submission and before peer-review. There can be important differences between the submitted version and the official published version of record. People interested in the research are advised to contact the author for the final version of the publication, or visit the DOI to the publisher's website.

- The final author version and the galley proof are versions of the publication after peer review.

- The final published version features the final layout of the paper including the volume, issue and page numbers.

Link to publication

\footnotetext{
General rights rights.

- You may freely distribute the URL identifying the publication in the public portal. please follow below link for the End User Agreement:

www.umlib.nl/taverne-license

Take down policy

If you believe that this document breaches copyright please contact us at:

repository@maastrichtuniversity.nl

providing details and we will investigate your claim.
}

Copyright and moral rights for the publications made accessible in the public portal are retained by the authors and/or other copyright owners and it is a condition of accessing publications that users recognise and abide by the legal requirements associated with these

- Users may download and print one copy of any publication from the public portal for the purpose of private study or research.

- You may not further distribute the material or use it for any profit-making activity or commercial gain

If the publication is distributed under the terms of Article $25 \mathrm{fa}$ of the Dutch Copyright Act, indicated by the "Taverne" license above, 


\section{HEMODIAFILTRATION}

THE SIMULTANEOUS APPLICATION OF HEMODLALYSIS AND HEMOFHLTRATION 



\section{HEMODIAFILTRATION}

\section{THE SLMULTANEOUS APPLICATION OF HEMODIALYSIS AND HEMOFILTRATION}

PROEFSCHRIFT

TER VERKRIJGING VAN DE GRAAD VAN DOCTOR IN DE GENEESKUNDE AAN DE RIJKSUNIVERSITEIT LIMBURG TE MAASTRICHT, OP GEZAG VAN DE RECTOR MAGNIFICUS PROF, DR. H.C. HEMKER, VOLGENS HET BESLUTT VAN HET COLLLGE VAN DEKANEN IN HET OPENBAAR TE VERDEDIGEN IN DE AULA VAN DE UNIVERSITEIT OP VRJJDAO 2 DECEMBER 1983 DES NAMIDDACS OM 16.00 UUR.

DOOR

JOSEPH ADRIANUS CORNELIS ANTONIUS VAN GEELEN

GEBOREN TE 'S-HERTOGENBOSCH 


$$
\begin{aligned}
\text { promotor : Prof. Dr. J.A. Flendrig } \\
\text { referenten : Prof. Dr. M.Y. Jaffrin, Compiègne } \\
\\
\text { Prof. Dr. K.H. Rahn, Maastricht } \\
\text { Dr.J.P. van Hooff, Maastricht }
\end{aligned}
$$


Aan :

Wilma, Guida, Veronique Miljn ouders 
CHAPTER I INTRODUCTION 1

CHAPTER II HISTORICAL REVIEW

A. Hemodialysia 3

B. Hemofiltration 9

C. The technical achievement of accurately 17 controlled ultrafiztration during hemodialysis and hemofititration

D. Conclusions

CHAPTER III THE CONCEPT OF A HEMODIAFILTRATIDN MODEL

(simultaneous hemodialysis and hemofiltration)

A. Mathematical aspects 24

B. Expeximental design and pizot study 28

c. Conctusions and nequirements for 33 hemodiafiztration equipment

CHAPTER IV DESIGN AND PRODUCTION OF A WOLUME CONTROLLED 36 HEMODIAFILTRATION APPARATUS

A. Teohntoal aspects 36

B. In vitro studies 41

c. Conclusions $\quad 55$

CHAPTER $V$ CLINICAL OBSERNATIONS 57

A. Teahniak aspects and cross-over study 57

B. In vivo evaluation of different treatment $\quad 66$ strategies

c. Conclusions 74

$\begin{array}{lll}\text { CHAPTER VI DISCUSSION } & 77\end{array}$ 
CHAPTER VII SAMENVATTING

CHAPTER IX APPENDIX

LITERATURE

ACKNOWLEDGEMENTS

109

CURRICULUM VITAE 
$+x$ 
CHAPTER 1. INTRODUCTION.

The preservation of live in patients with end stage renal disease is one of the major medical achievenents of the last decades. The human kidney was the first internal organ to be replaced by an artificial device. In the same era kidney transplantation has become possible, but not all patients can profit from this treatment. The artificial kidney, that up till now only partially replaces the function of the natural kidney, went through a stormy development. This has been stimulated by the awareness among physicians of considerable residual morbidity in patients, treated by chronic intermittent hemodialysis.

In the seventies suspicion arose that part of this morbidity might be ascribed to the retention of toxic metabolites, that are not removed from the body by conventional dialysis procedures. On the one hand this led to the development of new membranes for artificial kidneys, on the other hand it promoted the clinicall application of an entirely new technique, that bears resemblance to the function of the natural glomerulus and is called hemofiltration. The major drawbacks of this technique are the complicated technical equipment that is necessary for clinical application, and the limited clearing capacity, which depends on the maximum amount of filtrate that can be produced during one treatment session. However, it is possible to obtain an optimal profile of blood purification by combining hemodialysis and hemofiltration, thus coupling mass transport by simultaneous diffusilon and convection. This will cause the removal from the blood of waste 
products of small as well as larger molecular weight. The adwantages of this procedure on the long term are not clear, because clinfical experience is still rather limited.

The alm of the present study is :

a. to bring into practice simultaneous hemodialysis and hemofiltration, which will be called hemodifilitration, and to evaluate this kind of treatment on the long term in a pilat study.

b. To develop a mathenatical concept that analyzes the interaction of diffusive and convective mass transport and to verify the results by in vitro studies.

c. To design and construct sophisticated equipment for hemofiltration treatments, based on accurate wol ume control.

d. To gather clinical experience with this equipment and to study in vivo mass transport characteristics. 


\section{A. Hemodialysis}

The passage of crystalloid matter from urine into a water bath trough a parchment membrane was first studied by Thomas Graham in 1854, who called this phenomenon dialysis (Drukker 1983). This principle was applied to the purification of blood in animal experiments by Abel and coworkers in 1913.

In 1928 the first succesful hemodialysis procedure on a human being, using a cellaidin membrane, was conducted by Georg Haas in Gieszen. He used a new anticoagulant; heparin, introduced for this purpose by his countryman Necheles. He carefully observed a $20 \%$ reduction in the volume of blood that was brought outside the body and believed that it was due to osmosis. Actually it was the result of ultrafiltration, caused by a positive hydrostatic pressure on the membrane.

In the same year in Belgium, Brull, published on his ultrafiltration experiments in animals, in which blood under pressure from the carotid artery was exposed to a celloidin menbrane on a frame work of glass. He collected the ultrafiltrate and found that its mineral content was almost identical to that of plasma.

The defintte break-through of hemodialysis treatment was made by $W$. Kolff in Kampen, The Netherlands, who, together wit an engineer H. Berk, constructed a rotating drum dialyser in which the blood was propelled by rotation through 40 meters of cellophane tubing. In 1945 he reported on the first survivor of acute renal fallure (Kolff 1946). Although in the years following his invention many 
effective dialysers have been developed, it took another 15 years before the treatment of chronic renal faillure was succesfully undertaken. At the ASAIO meeting in Chicago 1960, Quinton, Dillard and scribner reported on an exteriorized arterio-venous bypass device made from tefion to provide a permanent vascular access, in order to perform an unlimited number of dialyses in a single patient. Initially a kill dialyser was used with a continuous flow dialysis system at low temperature to avold bacterial contamination of the dialysate. Later the system was changed into a singlle pass dialysate system at $37^{\circ} \mathrm{C}$, and in 1962 the seattle Group reported on 8 patients surviving their end stage renal failure from 4 months to 2 years.

After this there was a rapid expansion af dialysis therapy all over the world and in 1965 more than 160 patients were treated in 40 centers in Europe.

However, with growing experience it became clear that not all uremic symptons were relieved by this new therapy. Signs of neuropathy, osteodystrophy, persisting anemia, coagulation disorders, disturbances of carbohydrate and lipid metabolism, hypertension and cardiovascular diseases, most of which disappear after succesfull transplantation, were observed among dialysis patients.

Based upon his experience with peritoneal dialysis Scribner postulated at the ASAIO meeting in 1965 :

"Furthermore, as we 've mentioned in the past, if it is true that patients feel better on less dialysis, there is a chance that because the peritoneal membrane is leaky, we are removing with peritoneal dialysis centain higher molecular weight substances more efficlientiy than with hemodialysis, and this may account for the 
better results, and suggest that we need a leaky membrane for a hemodialyser". Shaldon had come to the same conclusion based on the apparent better clinical condition of patients dialysed on thin cuprophane membranes with $k i l l$ dialysers compared to patients dialysed on thick cellulose coil dialysers, in spite of cotil dialysers having a more efficient urea clearance (Shaldon 1983). These observations gave rise to the so called "Middle Molecule Hypothesis" formulated in 1972 by Babb and coworkers and were supported by observations of Tenckhof (1970) in peritoneal dialysis, by Jebsen (1967), who reduced the treatment time and by Ginn e.a. (1972) using dialysers with a small surface area.

The concept however was challenged by many investigators anong whom Kjellistrand $(1972,1973,1975)$ who stated that these renatning signs of uremia were the result of the non-physiological impact of hemodialysis on the "milieu interieur". Many investigators (Dzürik 1973, Bergström 1976a, Fürst 1976, Babb 1972, Migone 1975) attempted to identify these toxic Middle Molecules, i.e. solutes with a molecular weight between 600 and 5000 Daltons, and others (Cambi 1972, 1973. M11lora 1972, Shinaberger 1972, Sargent 1974, Maiorca 1974, Nakagawi 1977, Raja 1978, Graefe 1979) tried to discriminate between small and middle molecule clearances by manupulating treatment strategies. They did not succeed in proving or rejecting the middle molecule hypothesis and the concept has gradually become less convincing. 
On emplrical grounds Babb and Scribner concluded that the minimal clearance requirement for middle molecular toxins was considerably less than for small molecular toxins and it was estimated to be about 30 liters per week. This corresponds to a residual glomerular filtration rate of $3 \mathrm{ml} / \mathrm{min}$. Therefore, they conceived the "dialysis index", which expresses the middle molecule removal for any patient diallyser combination (Babb 1975). In this formulation the residual glomerular filtration rate is added to the in vitro clearance of the dialyser for a middle molecular substance. For this substance they choose Vit B12 having a molecular welght of 1355 Daltons.

This index was presented as follows:

$$
\text { D.I. }=\frac{{ }_{d} k_{B} t_{d}+60 \times 168 K_{k}}{(30.000)(5 / 1.73)}
$$

Where $n_{d}=$ the number of dialyses/wk,

$$
\begin{aligned}
& K_{B}=\text { dialyser clearance for Vit } B 12 \text { in } \mathrm{ml} / \mathrm{min} \\
& t_{d}=\text { the duration of each dialysis (min.) } \\
& 60 \times 168=\text { the number of min. in a week } \\
& K_{k}=\text { the residual renal clearance in } \mathrm{ml} / \mathrm{min} \text {, and } \\
& S=\text { the patient surface area. }
\end{aligned}
$$

A Dialysis Index equal to one yields the hypothetical minimum clearance of 30 liters per week for a middle molecular substance. Opponents (Teehan 1977, Gotch 1975, Lowrie 1981) of this formula 
emphasized the restrictions of this approach as the following assumptions are inherent to it $:^{1}$ the renal clearance of toxic middle molecules is equal to the glomerular filtration rate (which holds true for inulin; MW 5200 Daltons), ${ }^{2}$ these middle molecules are distributed in the body in a single pool and ${ }^{3}$ their production rate is a direct function of body surface area.

One could speculate that accumulation in the blood of toxic substances is not only the result of retention because of insufficient renal excretion, but rather the consequence of a stimulated synthesis in the way this applies for instance to parathoriton. With this so called "trade-off hypothesis" Bricker (1972 a and b) tried to explain some uremic symptoms, but it has not gained general acceptance. The main benefit of the dialysis index concept is that it enabled comparison of different treatment strategies and undoubtedly it substantially stimulated research in the field of dialyser design and membrane technology.

By application of sophisticated techniques of gel filtration and exchange chromatography, several investigators succeeded in separating fractions from uremic serum that were supposed to contain middle molecular toxins, as was assessed with standards of known molecular weight.

Indeed, Man and collaborators, isolated from the plasma of uremic polyneuropathic patients a fraction that exhibited an in vitro neurotoxic effect on an isolated frog sural nerve (Man 1973a, 1973b, 1974, 1980, Funck-Brentano 1972, 1978, Sausse 1974). This fraction was also present in the urine of healthy volunteers and in a significantly lower concentration in the plasma of uremic patients without polyneuropathy. 
Attempts to isolate and identify this neurotoxin were unsuccessful. However they managed to obtalin impressive improvement of severe polyneuropathy in several patients by using a polyacrilonftorle membrane which is very permeable to middle molecules. These data support the infdle molecule hypothesis but do not prove tt. 


\section{B. Remofititration}

In 1967 L. Henderson introduced hemofiltration as al alternative to hemodialysis treatments. This process is analogous to the production of ultrafiltrate in the human glomerulus and takes place under the influence of a hydrostatic pressure gradient. In contrast to the process of diffusion during dialysis, which is particularly effective for small molecular substances like urea with considerable Brownian motion, here, mass transport is by convection, which is equaliy effective for all molecular sizes. clearance is determined by filtration flux and membrane cut off, which means that pore-size restricts the passage of too large molecules.

Thus clearance of middle molecules during hemofiltration is considerably higher than during hemodialysis. As long as there is no way to imitate the process of reabsorption and secretion of the tubular cell, the filtrate must be discarded and the losses must be replaced by substitution of a modified Ringer-lactate solution. Before proceeding to clinical application Henderson experimented on laboratory animals and he used a capillary filter $\times$ M-50 (Amitcon) with a polysulfonate membrane and a surface area of $0.4 \mathrm{~m}^{2}$. A tendency to clotting and sludging phenomena in these capillaries was noted. For a saline solution there was a linear dependency of ultrafiltration flux on transmembrane pressure.

However for a protein containing solution there is a decline of ultrafiltration flux with high transmembrane pressures. This is due to protein coating on the membrane. For this reason Henderson. 
decided to dilute the blood and he added the substitution fluid to the blood before 1 ts entrance into the hemofilter. This was called predilution: figure 1 .

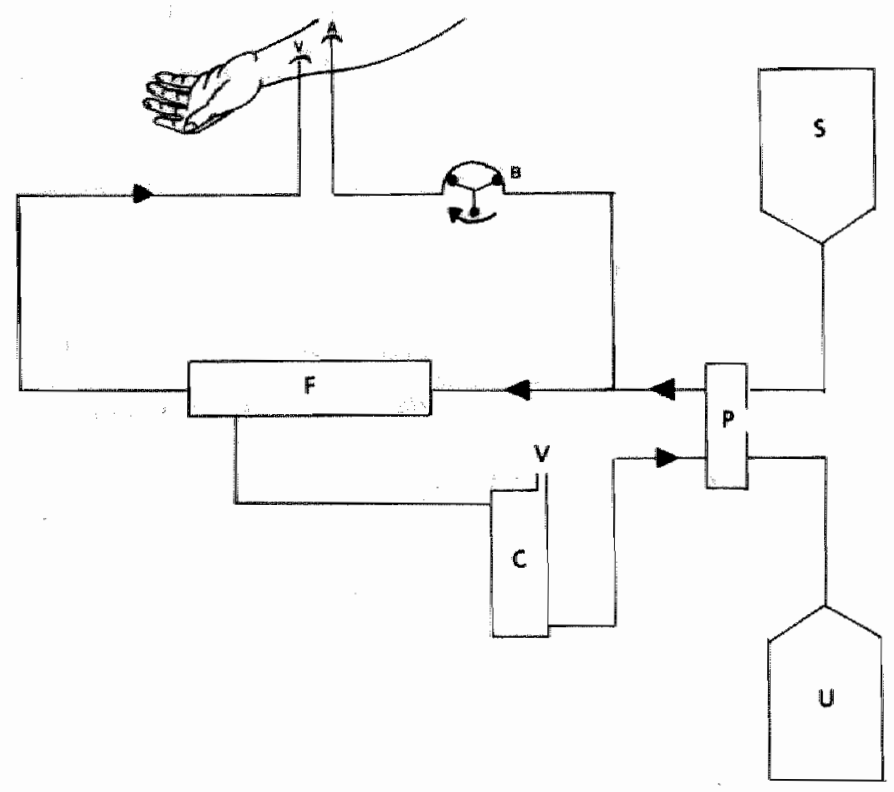

Figure 1 : predilution hemofiltration according to Henderson. B. bloodpump

C. collecting chamber

$F$. hemofilter

P. piston pump

U. ultrafilltrate

S. substitution fluid

V. vacuum source

His collaborators (Colton e.a., 1975) analysed the dependency of ultrafiltrate flux on transmembrane pressure difference, bloodflow, hematocitite, various protein concentrations, fiber length and diameter in a theoretical madel and tested it in in vitro studiles. 
On account of these data they elaborated a capillary filter with menbrane area of $1,6 \mathrm{~m}^{2}$, which was used by Henderson in clinical studies. In the predillution mode 70 to 100 liters of substitution fluid were consumed per 6 hour hemofiltration procedure (Henderson $1975 b)$.

The treatments were tolerated well and as expected inuline clearances were substantially higher than with conventional hemodially-

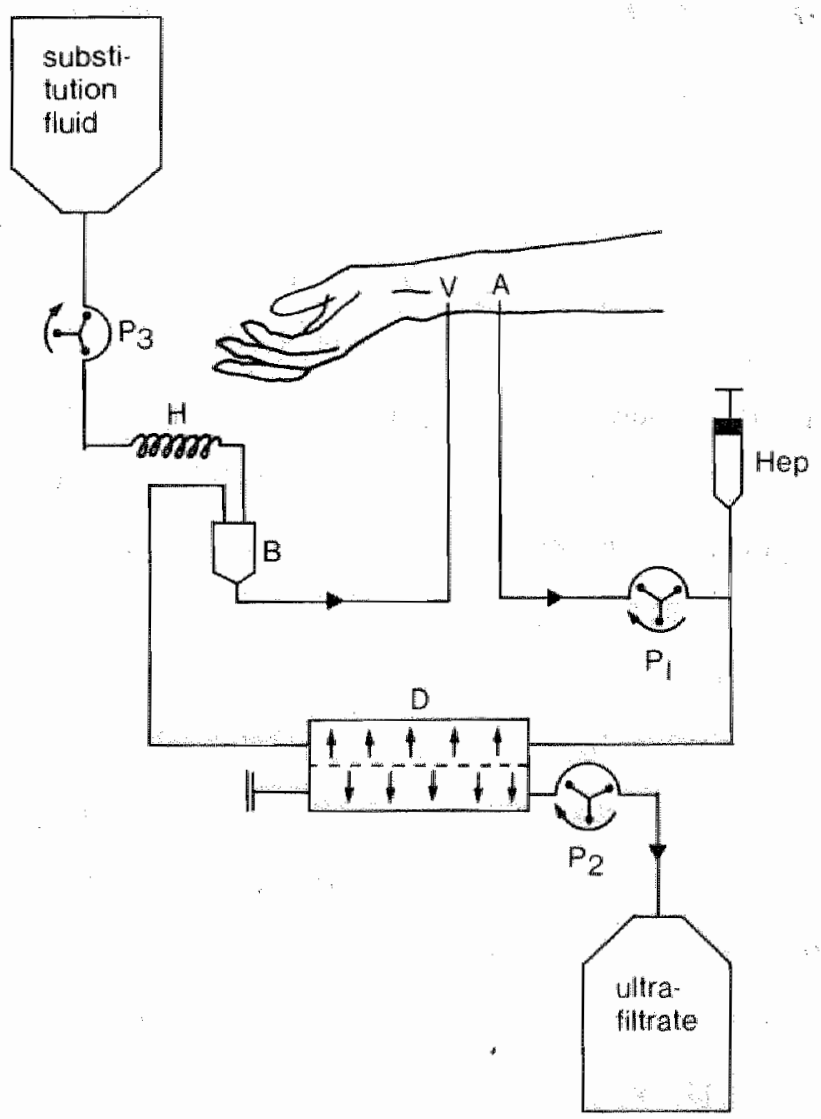

Figure 2 : Post dilution henofiltration according to Quellhorst. 
sis. However there was also considerable protein loss up to 20 to 30 grams per 6 hour period.

In Europe the first important clinical results were reported by quellhorst e.a.(1976). The major distinction from Henderson's studies was that the substitution fluid was added to the blood after passage through the hemofilter, which was called postdilution. This is schematically illustrated in figure 2 .

Thus per 41 hour hemofiltration treatment 18 to 20 liters of fluid were exchanged, using a RPG dialyser and later a special disc-like cellulose triacetate membrane from Sartorius. The substitution fluid had the following composition :

$\mathrm{Na}^{+} 135 \mathrm{mmol} / 1, \mathrm{~K}^{+} 2,0 \mathrm{mmol} / 1, \mathrm{Ca}^{++} 3,75 \mathrm{mmol} / 1, \mathrm{Mg}{ }^{++} 1,5 \mathrm{mmol} / 1$, $\mathrm{Cl}^{-} 108,5 \mathrm{mmol} / \mathrm{l}$ and lactate $33,75 \mathrm{mmol} / \mathrm{l}$.

The hemoconcentration, that is inherent to the postdilution mode, did not result in any adverse effect in the sense of blood cell damage. Protein 1055 amounted to 10 grams per treatment.

On 7 patients treated for 3 to 18 months by hemofiltration Quellhorst reported an improvement of hypertension, resistant to dialysis and drugs, anemia, hypertriglyceridemia, hyperphosphatemia, polyneuropathy and symptoms of dialysis discomfort, such as headache, nausea and cramps (Quel1horst 1977a, 1977b). By hemofiltration substances with a molecular weight over 300 Daltons were el Iminated more effectively than by hemodialysis. Removal of small molecular solutes however was considerably less effective, resulting in high pretreatment levels of urea and creatinine, but this did not obviously harm the patients.

His most remarkable abservation was the normalisation of severe hyperreminemic, drug and dialysis resistant hypertension in 12 
out of 13 patients in the course of 7 months (quellhorst 1979a, 1979b). This nomalisation of blood pressure was not simply a function of extracellular fluid withdrawal (i.e. volume dependent), because there was a parallel decrease of plasma renin activity. On the other hand he noted that fluid withdrawal during hemofiltration in nomotensive patients was tolerated well and not accompanied by blood pressure drops or disequilibrium symptoms such as headache or woniting, which is often seen during fluid withdrawal in conventional hemodialysis. This phenomenon was explained by the relatively small change in extracellular osmolarity during hemofiltration while during the course of a hemodialysis procedure plasma osmolarity decreases significantly, resulting in a fluid shift from extracellular to intracellular space and consequent shrinking of the vascular compartment (Pogglitsch 1978, Rouby 1978, Aizawa 1979).

Interestingly the same degree of vascular stablity was observed by Bergström e.a. in 1976 who treated severely overhydrated patients with sequential ultrafiltration - hemodialysis. In this treatment strategy ultrafiltration precedes the hemodialysis session and thus the symptomless rapid fluid withdrawal is also established under iso-osmotic conditions (Bergstión 1976, 1978a. 1978b; Pierides 1978, Ivanovich 1978). Their theory was challenged by many investigators among whom Henderson who states that both resistant hypertension and unstability of blood pressure during treatments is caused by a defect in baroreceptor function due to the retention of toxic middle molecules (Henderson 1975a " 1977. 1980, Graefe 1977, Jones 1977, Spohr 1980).

An important observation shared by varfous authors, is that vascu- 
lar stability during hemofiltration appears to be due to an adequate adaption of the peripheral vascular resistance in response to fluid withdrawal, which might be medilated by increased catecholamine levels (shaldon 1979, Wehle 1979). Whatever its cause may be, it is not seen during hemodialysis and this remarkable discovery is still a matter of much debate (Baldamus 1982).

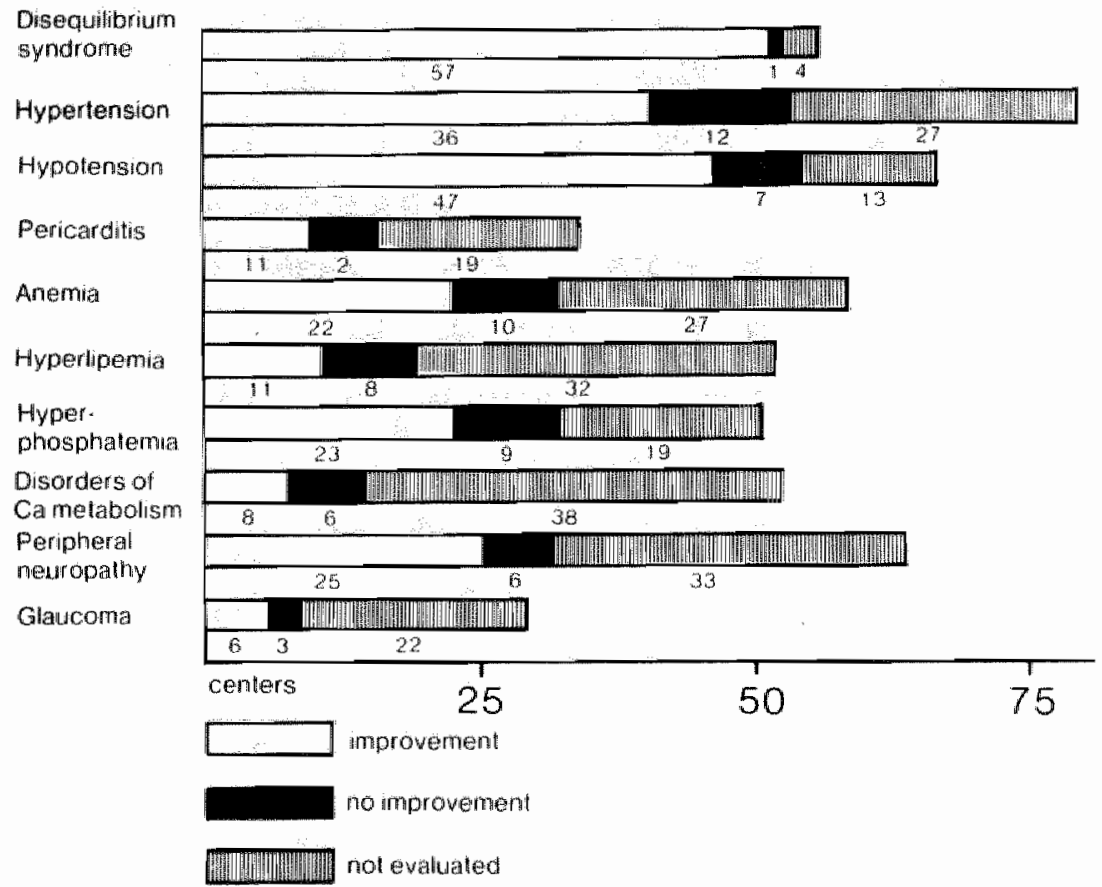

Figure 3 : Change in the occurrence of uremic complications after switching from conventional hemodialysis to hemofiltration or hemodiafiltration. Survey from 108 Japanese centers. Data from M. Maekawa e.a. 0saka 1980 (Artificial Organs $4,2,85$ ).

The benefits of hemofiltration with regard to the metabolic disturbances in uremia have not been confirmed in the long term. 
(Baldamus 1978, 1980, Henning 1980, Nagakawa 1980, Schaefer 1980, Schneider 1979, Streicher 1980).

Henning fomulated the following indications for the application of hemofiltration treatment (Henning 1980).

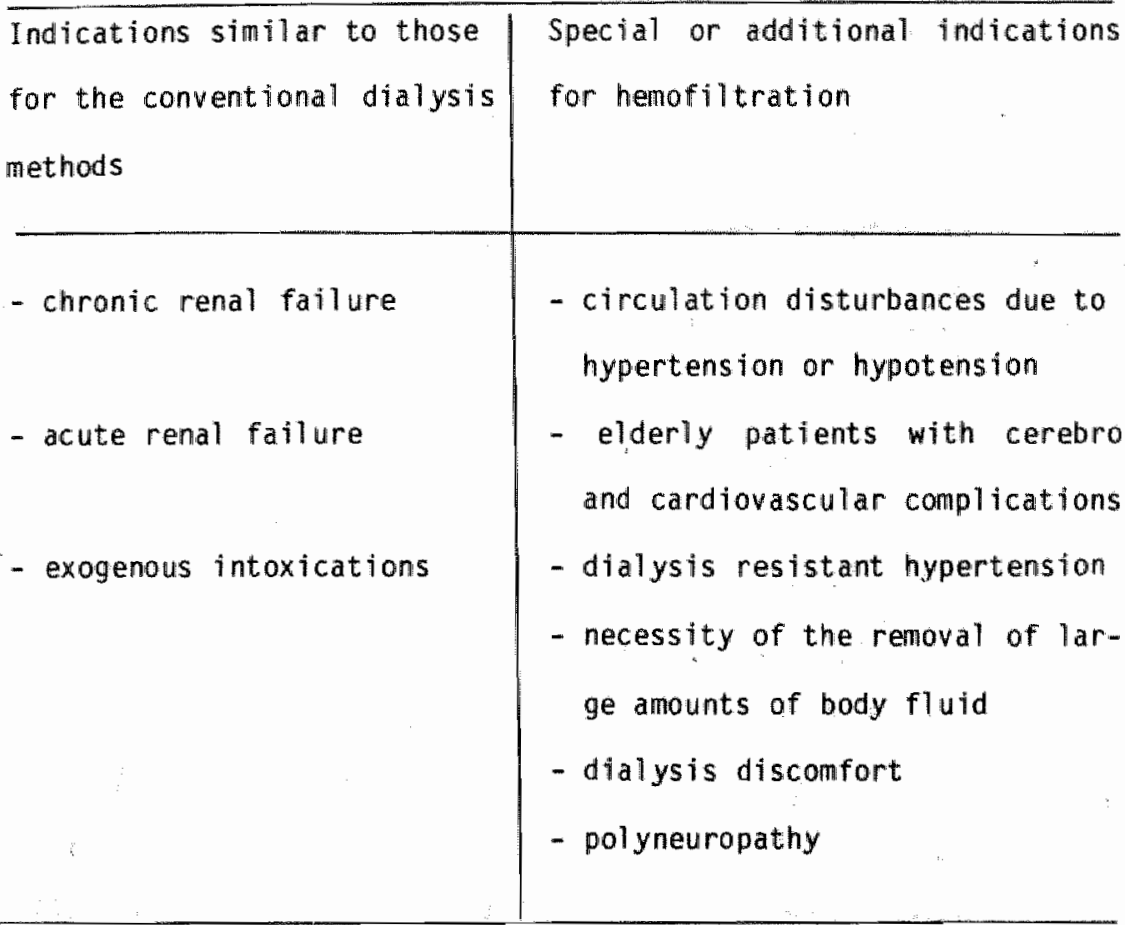

This can be seen from a Japanese survey of the resultis of hemofiltration treatments in 108 different centers till Apr 11 1979 (Maekawa 1980). 182 patients were treated by hemofiltration and 134 patients received simultaneous hemodialysis and hemofiltration treatments which is also called hemodiafiltration. Convincing improvement was only reported wth regard to the disequillibrium syndrome and hypotension, as shown in figure 3 .

Hemodiafiltration was introduced in Germany by Leber e.a. (1978). By this procedure both small solutes and larger molecules 
are eliminated effectively in contrast to hemofiltration where clearance of small solutes is low. Therefore, treatment time can be reduced by $25 \%$ or more. Athough the advantages of this procedure are obvious, the clinical application is limited by the complicated and expenstve electronic equipment that is necessary to control the fluid balance. Therefore continuous superwision by stafmembers is required.

The operating conditions of Leber were the following :

- a single pass dialysis circuit with a dialysate flow of 800-900 mil $/ \mathrm{min}$.

- an ultrafiltration rate of $50-60 \mathrm{ml} / \mathrm{min}$.

- a RP6 diallyser in which a positive pressure in the bload circuit generated a transmembrane pressure of $550 \mathrm{mmHg}$

- treatment schedule of $3 \times 3 \mathrm{hr} /$ week.

After 21 years a follow up of 10 randomly selected patients who had been treated with either conventional hemodialysis $(3 \times 4$ hr/week, $1.4 \mathrm{~m}^{2}$ surface area Cuprophan dialyser) or HF/HD $(3 \times 3$ hr/week, RP6 dialyser) was performed (Leber 1980). No differences could be detected with regard to the values of urea, creatinine, phosphate, hemoglobin, acid-base status, blood pressure, the degree of polyneuropathy, hyperlipidemia and renal osteodystrophy in spite of a $25 \%$ peduction in treatment time and a $40 \%$ reduction in membrane area during $H D / H F$. The only advantage of HD/HF treatments was the better tolerance that manifested itself in less disequilibrium symptoms, less hypotensive episodes and better tolerated fluid withdrawal. When compared with hemofiltration alone the only obvious advantage was a reduction in treatment time as the total amount of ultrafiltrate per treatment can be reduced from 20 to $9-11$ liters. 
c. The teohntal arhevement of accurately controlved utrafituration duning hemodiatusts and nemofiteration.

In the application of Quellhorst the rate of ultrafiltration and the rate of reinjection of substitution fluid were balanced by gravimetrically guided dewices, that included rather compllicated microprocessors and expensive electronic bed scales. In conventional hemodialysis there is some ultrafiltration depending upon the desired weight reduction. This is usually produced by creating a negative pressure in the bath compartment to cause a fluid shift to the bath compartment. However the amount of ultrafiltration is not well controlled by this method. This, applies especially to the hing flux dialysers like the RPG that not only has an increased permeability to middle molecules, but also a tenfold increase in hydraulic permeability.

Therefore Funck-Brentano e.a.(1972) used a closed recirculating circuit with a fixed wolume of 75 liters in order to prevent uncontrollable fluid losses: the Rhodial that is schematically shown in figure 4. For ubiquitous application of high flux dialysers in conventional single pass hemodialysis circuits there is need for a technical solution for automatic and accurate control of ultrafiltration.

In 1975 this was accomplished by the dialysis group from the Catharina Hospital. Eindhoven, by the construction of a new device, that per unit of time introduces exactly the same amount of dialysate into the dialyser as is discharged from it. Together with the dialysate compartment of the dialyser this device constitutes a closed dialysate circuit with a fixed volume. Ultrafiltration is achieved by withdrawal of fluid from this circutt and the 


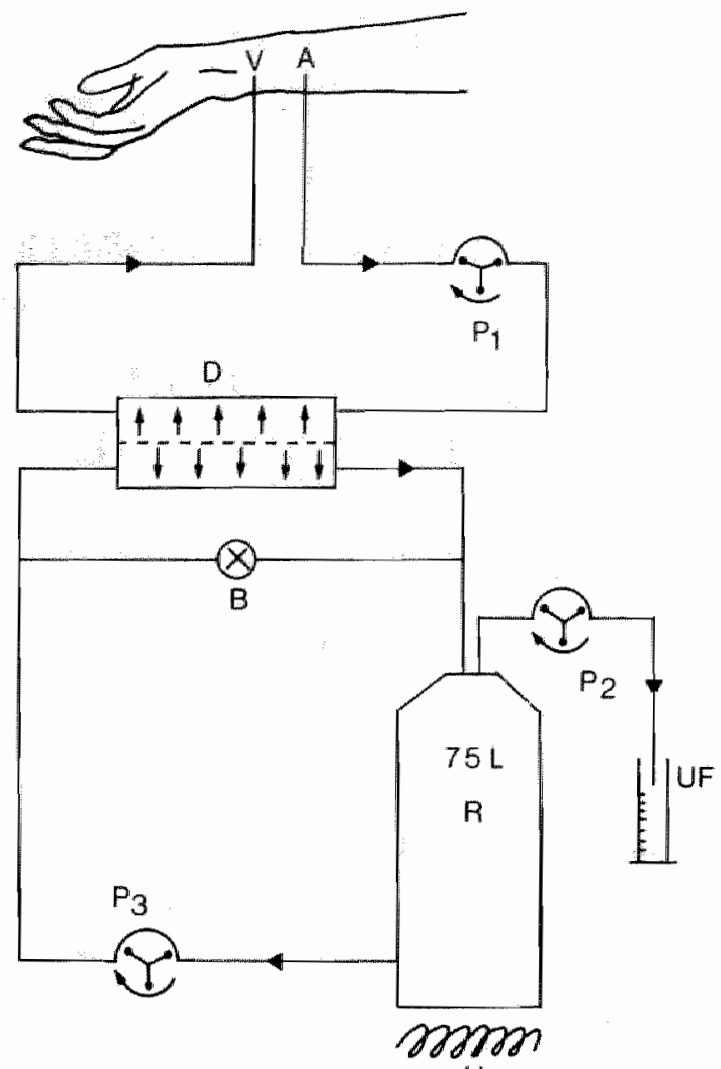

$\mathrm{H}$

Figure 4 : The closed circuit of the Rhadial system for hemodialysis and ultrafiltration control using highty permeable membranes.

resulting negative pressure in the dialysate circuit causes a fluid replacement from the blood compartiment equal to the amount of ultrafiltrate. The ultrafiltrate is collected in a measuring glass and the ultrafiltration rate can be adjusted to any desired and predetermined level. This apparatus is not only suitable for 
single pass dialysis using high flux dialysers, but also for hemafiltration purposes.

The technical details of this apparatus have been described in detail elsewhere (Flendrig 1978).

The operating characteristics and its position in the diallysate circuit are schematically shown in figure 5. The pump consists of two cylindrical compartments $(I+I I$ and III + IV $)$ of equall size, that are connected in line. Each compartment is subdivided into two segments, separated by a piston. Both pistons are mounted on a common shaft and they operate in concordance in each compartment. In the top drawing the pistons move to the left and the left compartment is connected to the dialyser. In the botton drawing the direction is reversed and the right compartment is connected to the dialyser. The necessary change of connections is brought: about in the main switching system situated above the pump. This change, however, is initiated by the common shaft in the pump, just before the end of a pump stroke, by means of two small limit switches located at both ends of the shaft.

Insight in the function of these limit switches can be gathered from figure 6a. At the end of a pump stroke the shaft ends set in motion two small. hollow plungers. At certain intervals these plungers are surrounded by 0 -rings in sliding contact with the cylinder wal1. The displacement of these 0-rings will open new communications with the main switching system and this causes the driving pressure, exerted by the pressure of the dialysate supply, to be transmitted to the ather end of the plunger in the main switching system. This will cause the plunger in the main switching system to move to the other ste, thereby setting free the 

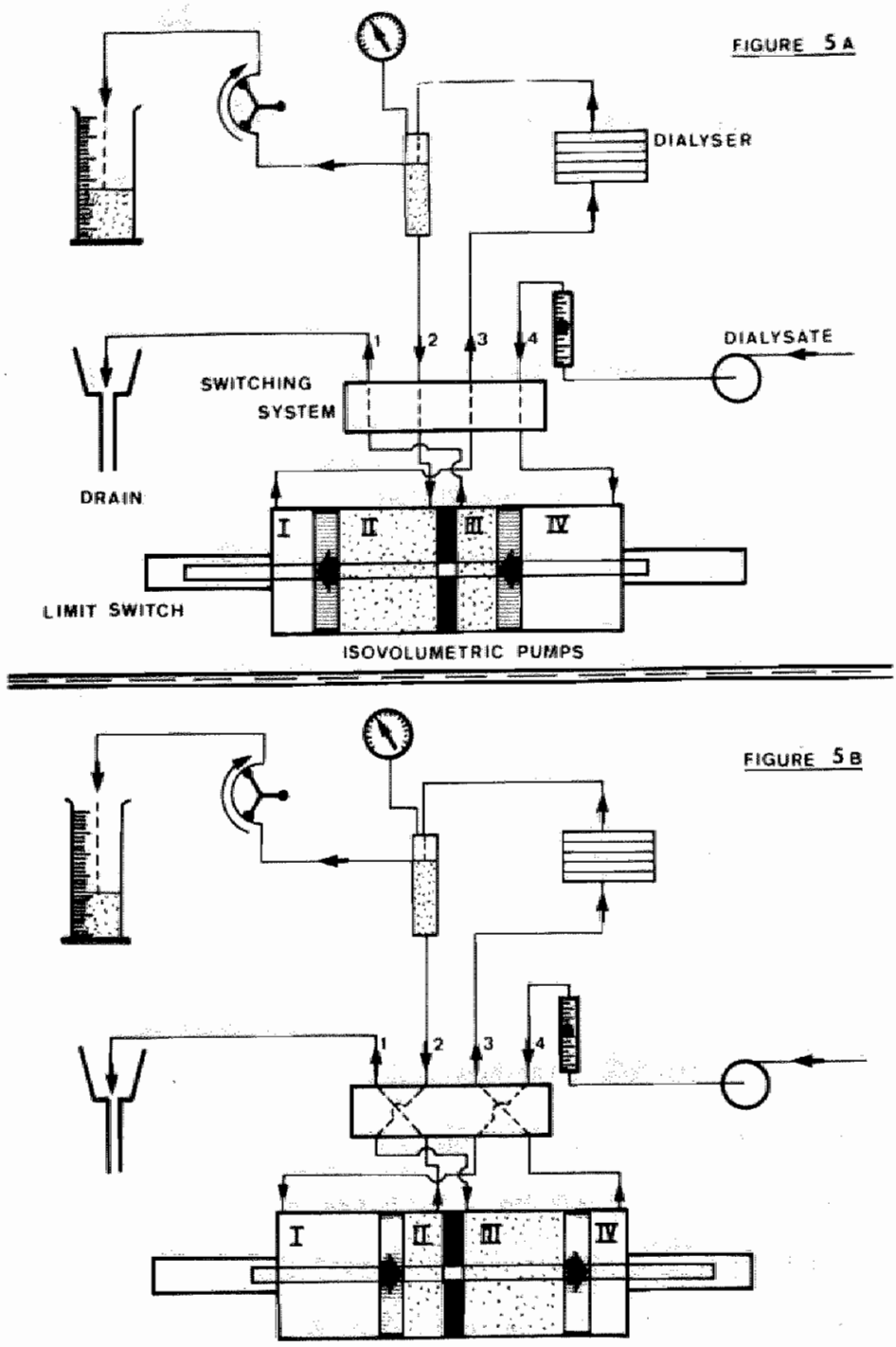

Figure 5 : Controlled ultrafiltration in a single pass hemodialysis circuit by means of isovolumetric pumps. 


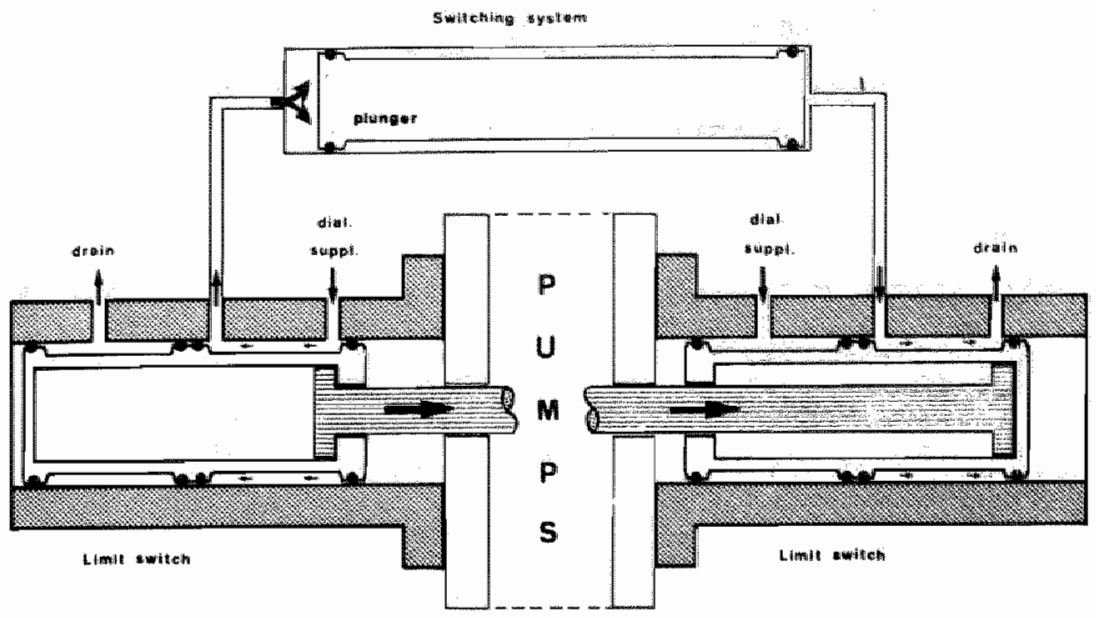

Figure 6a : The limit switches at both ends of the pumps.

FIGURE $0 \mathrm{~b}$

SWITCHING SYSTEM
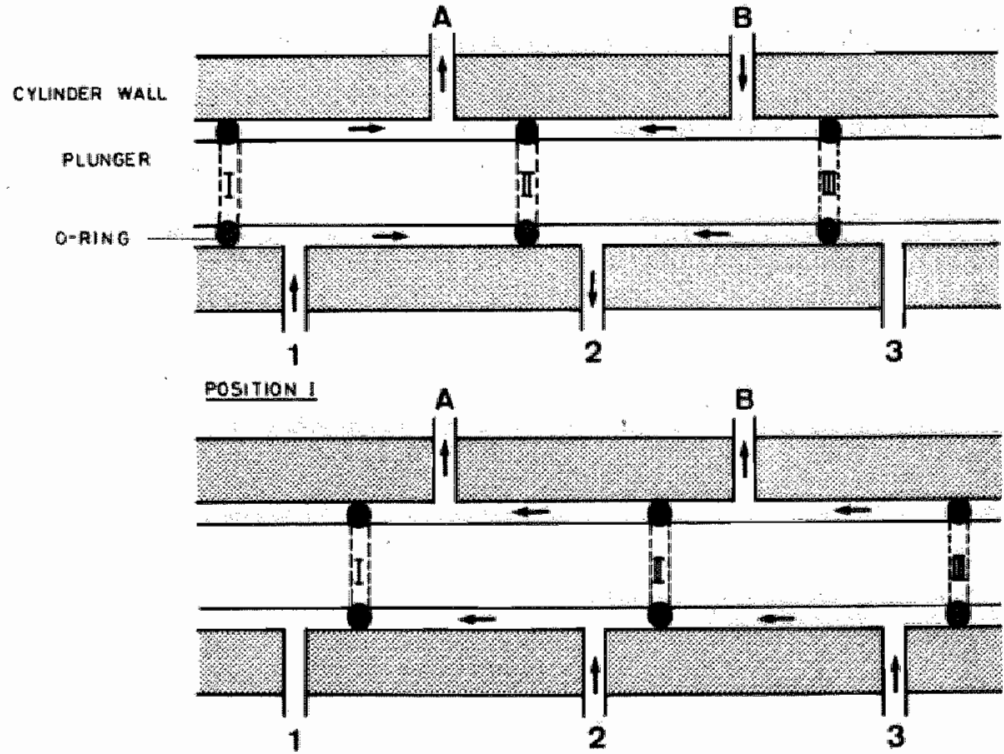

POSITION

Figure $6 b$ : The principle of the switching system. 
new connections as 45 shown in figure $6 \mathrm{~b}$.

Subtle time sequences just before the end of the pump stroke are essential for the proper functioning of this mechanical pump, that permanently operates under the driving pressure of 0.5 atm. The bath compartment of the dialyser and the pump, together with the connecting lines, form a pemanently closed circuit, from which ultrafiltrate can be extracted by a simple peristaltic pump, as indicated in figure 5. This garantees exact control of fluid withdrawal from the patient.

The construction and functioning of the apparatus is such that calamities will not easily occur. It is very simple to accurately control ultrafiltration with this apparatus with regard to not only the total amount of fluid which must be extracted but also the regularity of flutd extraction.

In over 50.000 hemodialysis treatments with several types of dialysers in an open single pass dialysate circuit with central delivery, ultrafiltration was always accurate within the measuring limits and the incidence of symptomatic hypotension has decreased dramat lcally. Technical fatlures have not been abserved. 
The advantages of hemofiltiration are the improved hemodynamic tolerance of the treatment and the high clearance of middle molecular toxins. The disadvantages are the low clearance of small molecular toxins and the complicated and expensive equipment.

Simultaneous hemodialysils (HO) and hemofiltration (HF), also called hemodiafiltration (HDF), can, on theoretical grounds, be considered to be today the optimal artificial kidney treatment, as it provides an optimal clearance pattern due to the combination of diffusive and convective mass transport.

For this treatment modality the development of dialysers with specialised high flux membranes has been essential. For the safe application of this treatment in a single pass dialysate circuit, the availlability of an accurate ultrafiltration control device is indispensible. This technical problem is the main reason why up till now hemodiafiltration treatments have been confined to a relatively small number of scientifically oriented centers and clinical experience is still limited (Kohnle 1979).

The isovolumetric ultrafiltration pump described in this chapter opens up new possibilities and enables hemodiafiltration treatments to be performed in a relatively simple way. 
CHAPTER III. THE CONCEPT OF A HEMOD IAFILTRATION MODEL.

\section{A. Mathematioal aspects}

In order to predict dialyser clearances during HDF we developed a mathematical model to describe mass transport by simultaneous diffusion and convection. This model applies to the in vitro situation and avoids the incorporation of immeasurabie assumptions. Thus the impact of protein coating on the membrane on the transmittance of various solutes is not considered. In HDF the overall clearance is less then the sum of clearances of dialysis and ultrafiltration occurring separately because of interaction between the two processes.

- On the one hand there is a continuing decrease in the blood flow along the membrane due to ultrafiltration causing a reduction in diffusive transport.

- On the other hand the presence of dialysis will cause the solute concentration to drop continuously along the membrane thereby reducing the contribution of ultrafiltration to the overall clearance (Jaffrin, 1981). In this one dimensional model the following situation is contemplated in the cocurrent made:

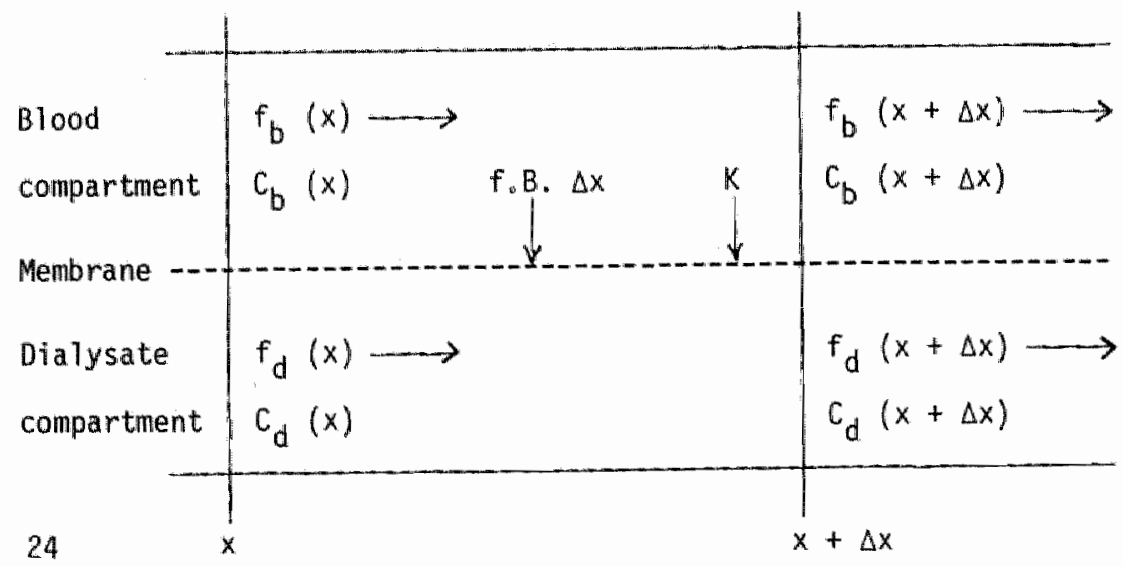


$f=f l u x$

$\mathrm{C}=$ concentration

$b=b l o o d$

$d=$ diallysate

$k=$ diffusion constant

$x=$ coördinate in flow direction

$B=$ membrane area

The major assumptions are:

1 The transmittance of all solutes is considered to be equal to unity.

2 The UF flux is constant along the membrane length.

Therefore it is postulated that the transmembrane pressure is low enough and concentration polarization does not occur.

(In fact in 1981 Jaffrin and coworkers showed that the solution in presence of concentration polarization is very close to the approximate solution when the UF flow is constant).

3 Blood and dialysate flow are considered to be constant.

4. A concentration gradient only exists in the direction of flow.

This model gives the following expression for the mass balance of the blood and diallysate compartment in the presence of simultaneous diffusion and convection :

$f_{b}(x) \cdot C_{b}(x)-f_{b}(x+\Delta x) \cdot C_{b}(x+\Delta x)-f \cdot B \cdot \Delta x \cdot C_{b}(x)-K \cdot B \cdot \Delta x\left(C_{b}(x)-\right.$ $\left.c_{d}(x)\right)=0$

and

$f_{d}(x) \cdot C_{d}(x)-f_{d}(x+\Delta x) \cdot C_{d}(x+\Delta x)+f \cdot B \cdot \Delta \cdot \cdot \cdot C_{b}(x)+K \cdot B \cdot \Delta x\left(C_{b}(x)-\right.$ $\left.c_{d}(x)\right)=0$ 
From these expressions of mass balance clearance can be calculated by integration and substituting boundery conditions.

Step-wise elaboration of these equations is given in the appendix. The ultimate fractional clearance $\left(\mathrm{Cl} / \mathrm{Q}_{b}\right)$ is given by the following equation, corresponding to the solution given by Jaffrin :

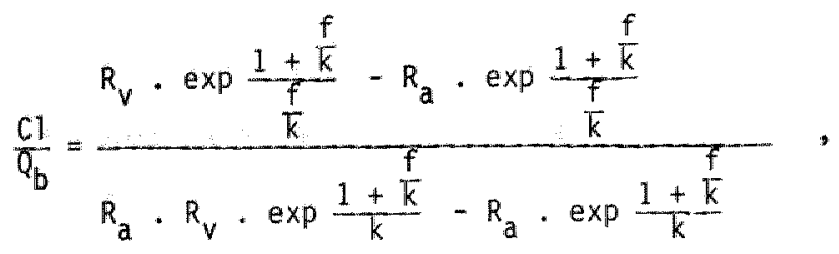

where: $\mathbb{R}_{v}=\frac{Q_{b}-Q_{F}}{Q_{d}}$ and $R_{a}=\frac{Q_{b}}{Q_{f}+Q_{d}}$

whilch are the ratios of the flows at the venous and arterial side of the dialyser in the countercurrent made.

The predicted fractional clearances according to this equation are shown in figures 7 and 8 for various solutes, in the RP6 dialyser. In hemodiafiltration, clearance of middle molecules appears to be much higher than in hemodialysis.

Al so at low dialysate flows clearance of small molecules in hemodiafiltration is high. 


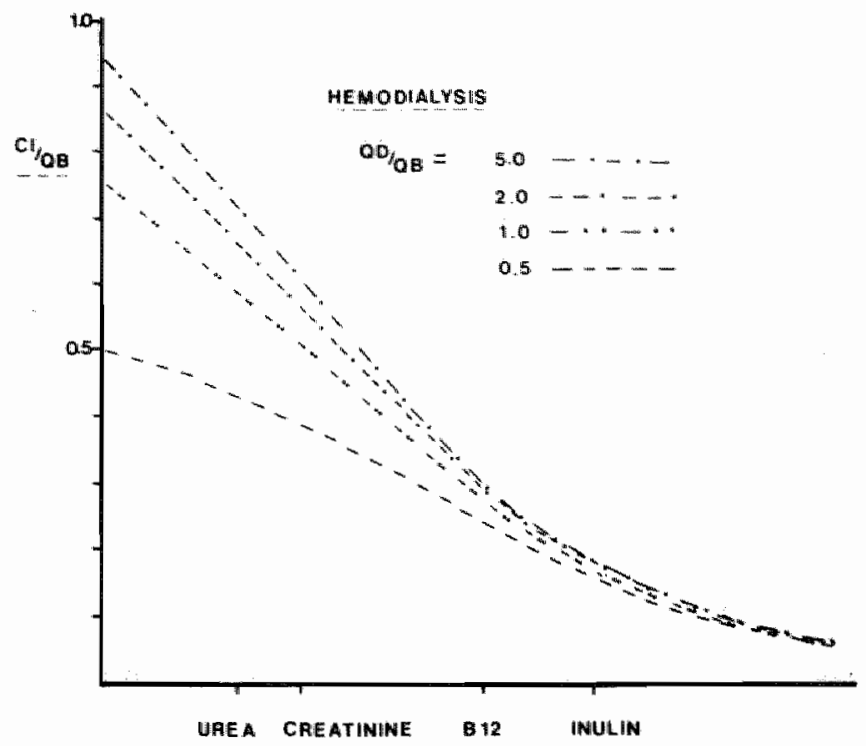

Ho. g. IA W W

Figure 7 : The predicted relative clearances in hemodialysis for various flow ratio's $\left(Q_{D} / Q_{B}\right)$ in a R.P. 610 dialyser.

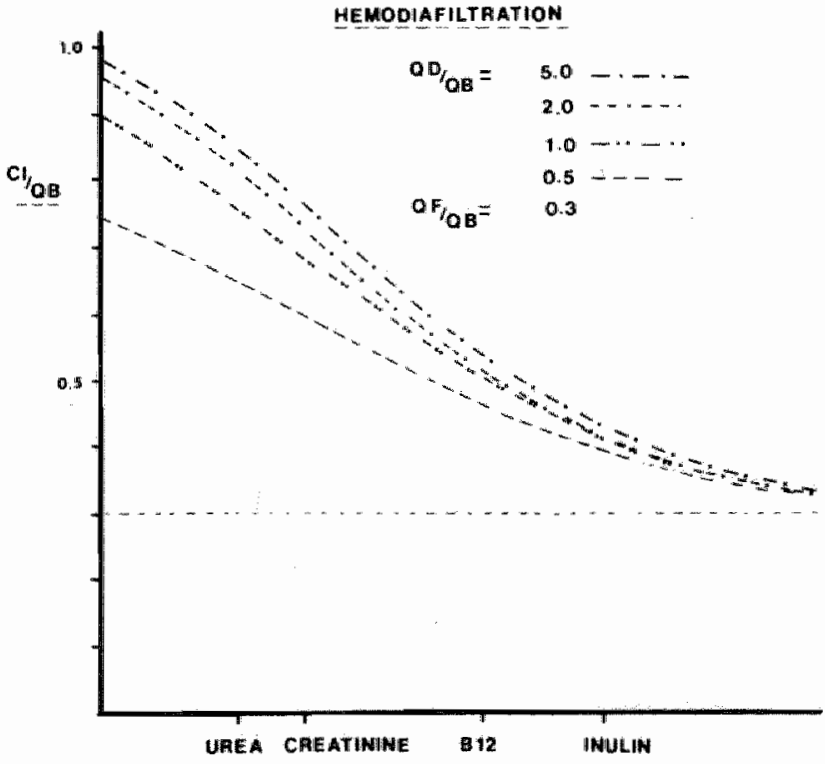

$\log , W$

Figure 8 : The predicted relative clearances in hemodiafiltration for various flow ratio's $\left(Q_{D} / Q_{B}\right)$ in a $R_{.} .6 .610$ dialyser $\left(Q_{\mathrm{F}} / \mathrm{O}_{\mathrm{B}}=0.3\right)$. 
At the beginning of our investigations in November 1977, no clinical experience with hemodiafiltration was reported in the literature. Therefore this pilat study, that was performed from November 1977, till June 1979, was intended to inwestigate the tolerance of this kind of treatment and to study the ling term effects.

Technically hemodiafiltration was achieved as illustrated in figure 9 using the ultrafiltration pump, that has been described in the second chapter, in a single pass dialysis cilrcuit with a RP6 dialyser. A constant ultrafiltration rate of $50 \mathrm{ml} / \mathrm{min}$. was generated, resulting in a negative pressure in the dialysate circuit of about $250 \mathrm{mmHg}$. Thus, during a $3 \frac{1}{2}$ hour treatment session, there was a withdrawal of 101 liters of ultrafiltrate. The

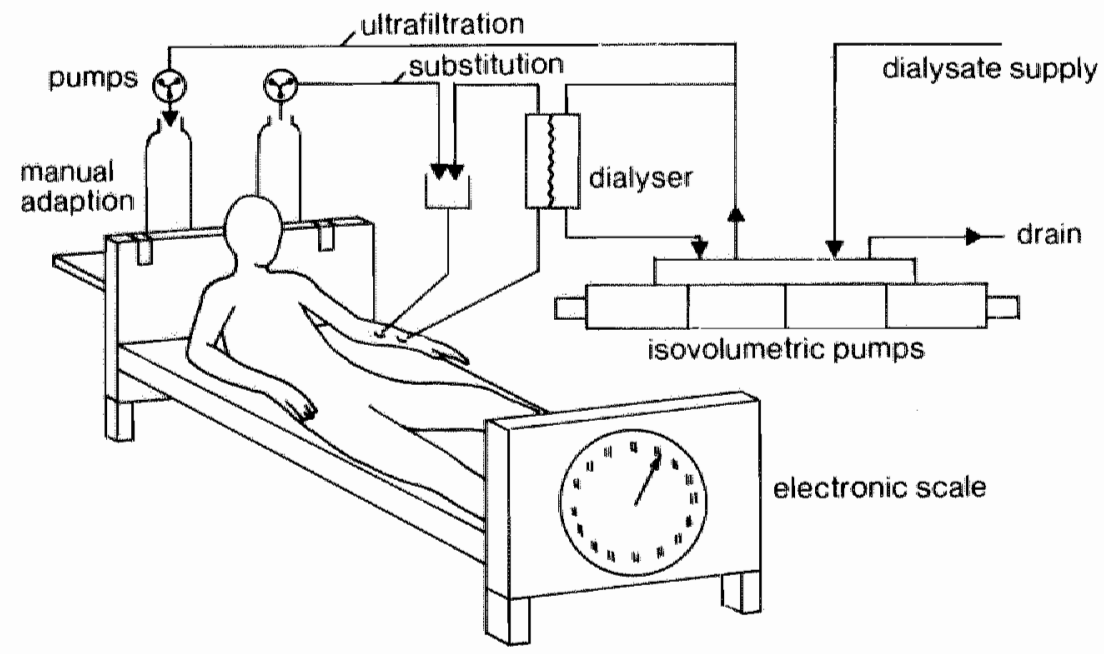

Figure 9 : Experimental set-up in the pilot study. 
substitution rate was adapted manually, using an electronic bedscale, whille observing the desired reduction of body weight.

The substitution fluid and the dialysate had the following composition :

\begin{tabular}{|l|c|c|}
\hline & $\begin{array}{c}\text { substitution fluid } \\
(\text { mmol/1) }\end{array}$ & $\begin{array}{c}\text { dialysate } \\
(\text { mmol/1) }\end{array}$ \\
\hline sodium & 138 & 134 \\
potassium & 1,0 & 2,0 \\
chloride & 107 & 103 \\
calcium & 1,9 & 1,55 \\
magnesium & 0,75 & 0,70 \\
acetate & - & 35 \\
lactate & 37,5 & 14 \\
glucase & - & - \\
\hline
\end{tabular}

The bloodflow $\left(\mathrm{Q}_{B}\right)$ was kept at $200 \mathrm{ml} / \mathrm{min}$. and the dialysate flow $\left(Q_{0}\right)$ at $500 \mathrm{~m} 1 / \mathrm{min}$.

During 18 months the proposita, being a 25 year ald female patient of $52 \mathrm{~kg}$, was treated thrice weekly for 31 hours. This patient became almost anuric in the course of several weeks due to rapidly progressive glomerullonephritis whth circulating antibodies against human glomerular basement membrane and extracaptllary proliferation in inght microscopic examination. 
Chronic intermittent hemodialysis with a RP6 dialyser was started in January 1975, thrice weekly for $3 \frac{1}{2}$ hours.

In addition she recefved 5 grams of colloidal aluminium hydroxide because of high phosphate levels and a dietary restriction of 50 grams per day of protein and a fluid intake of $500 \mathrm{ml}$ per day. Transplantation was considered and in June 1975 nephrectomy of the right kidney was performed.

However, after this, she objected to transplantation. She felt well during hemodialysis and she fulfilled a part-time job.

Her nemoglobin level was only 4,5 mol/1 receiving one unit of packed cells every month. The major drawback of dialysis treatment was the occurrence of painful muscle cramps in response to fluid withdrawal, which was seen during every treatment to a variable extent.

In November 1977, she consented to switch-over to hemodiafiltration treatments for the next $1 \frac{1}{2}$ years.

During hemodiafiltration tolerance to fluid withdrawal was improved and hypotensive episodes with painfull muscle cramps and nausea disappeared, in spite of the fact that in the preceeding years in conventional hemodialysis the ultrafiltration pump was used to ensure accurate fluid withdrawal. During conventional hemodialysis there was an average drop of serum osmolality of 30 mosnol/kg, while during henodiafiltration serum osmolality dropped only 15 mosmol $/ \mathrm{kg}$. The desired weight loss was always achieved accurately.

The combined load of acetate and lactate did not provoke obvious side effects, although metabolic acidosis was not completely corrected. 


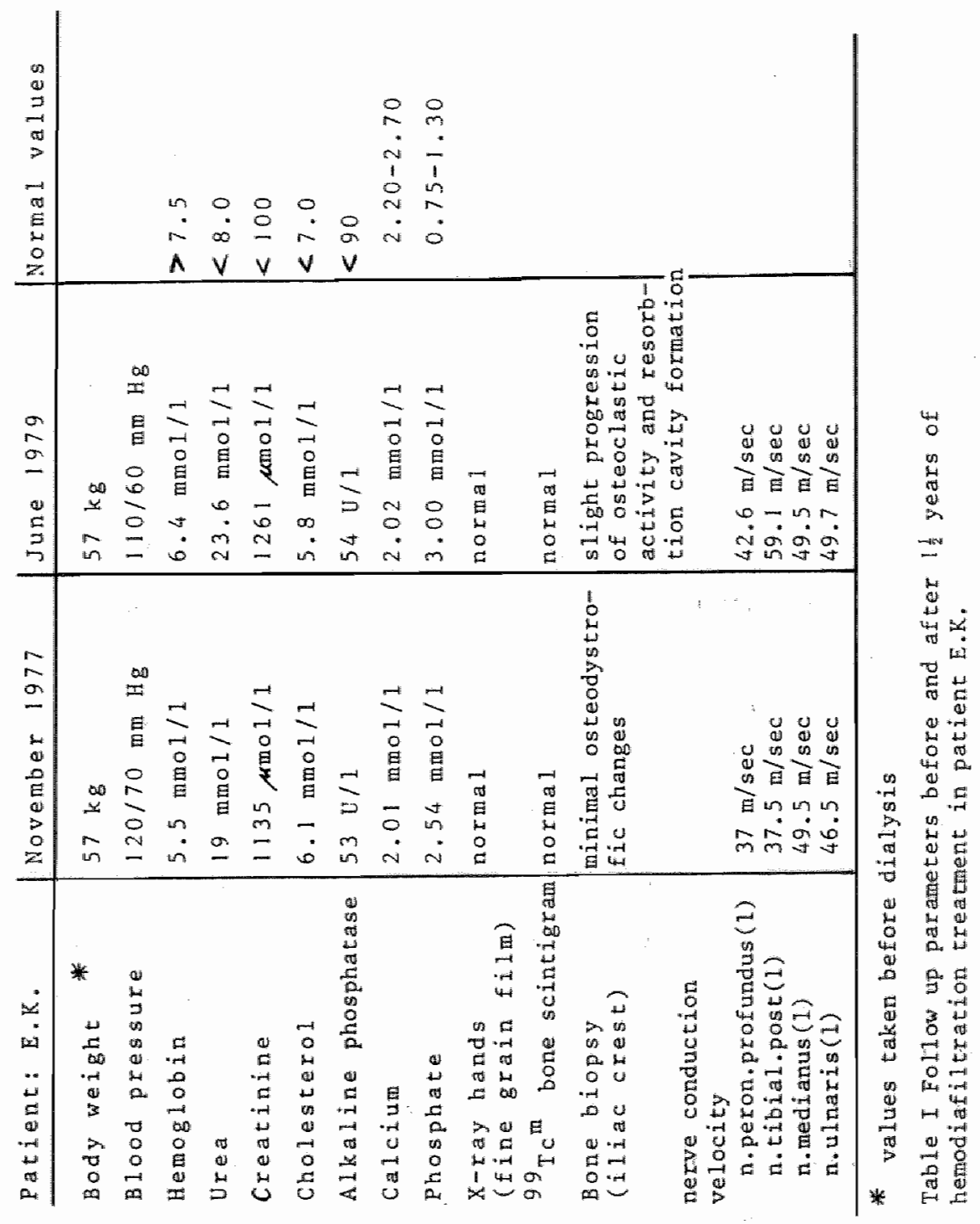


The long term effects of hemodiafiltration with respect to some relevant paraneters are sumarized in table 1.

The most important observation was a gradual rise of hemogllobin lewel from 4,5 to $6,5 \mathrm{~mol} / 1$, while blood transfusions were discontinued during hemodiafiltration.

Cother rellevant hematological parameters were namal: serum iron 12 umol/1, total Iron binding capacity 47 dmol/1, ferritine 224 $\mu \mathrm{g} / 1$, folic acid 14,1 nonol/l and vitamin B12 $314 \mathrm{pmol} / \mathrm{l})$.

In July 1979, when she turned back to conventional hemodialysis treatments the hemoglobin level gradually dropped to less than 5 moll/, and donations of packed cells were resumed at regular intervals.

Serum phosphate levels have constantly been too high throughout the observation period, giving rise to the development of secondary hyperparathyroidism and histological signs of renal asteadystrophy (type 1 according to Delling). There were no signs of osteonalacia.

The abnormalities in the bone biopsy showed a slight progression in the course of $1 \frac{1}{2}$ years of hemodiafiltration treatment. There have been no avert signs of uremic neuropathy and electromyografic examination was normal, except for a slight reduction in motor nerve conduction vellacity of the left leg that disappeared in the course of 1 years of hemodiafiltration treatment.

In conclusion the most important advantage of hemodiafiltration theatments was the good tolerance of the procedure, especial$1 y$ with regard to fluid withdrawal, and except for a rise of the hemoglobin level there were no changes of significance on relevant clinical parameters in the long term. 
c. Conctusions and requiremente for henodiafitration equipment

In formula III the dependency of the fractional clearance $\left(\mathrm{Cl} / \mathrm{Q}_{B}\right)$ of various solutes during hemodiafiltration on the relative blood-, dialysate- and ultrafiltration flows has been worked out. Obviously, during hemodiafiltration, a reduction of the dialysate flow to $25 \%$ permits urea and creatinine clearances that are comparable to conventional hemodialysis with high dialysate flows. This means that if hemodialysis is carried out with a dialysate flow of $400 \mathrm{ml} / \mathrm{min}$., in hemodiafiltration a dialysate flow of $100 \mathrm{ml} / \mathrm{min}$. would suffice, the bloodflow being $200 \mathrm{ml} / \mathrm{min}$. and the ultrafiltration flow $66 \mathrm{ml} / \mathrm{min}$.

In figure 10 these representative curves are brought together. It can be seen that despite the low dialysate flow hemodiafiltration yields much higher clearances for middle molecules" than hemodialysis. However, it should be kept in mind that these predictions apply to the in vitro situation in which it is assumed that there is a laminar flow, evenly distributed in the dialyser with no concentration gradients in a plane perpendicular to the membrane, and a solute transmittance equal to unity.

The first clinical experiences in hemodiafiltration during the pillot study were favourable and showed excellent tolerance on the short and long term.

Uremic manifestations, traditionally considered to be related to the retention of toxic middle molecules, could in this patient not be assessed on the basis of usual clinical parameters in the 


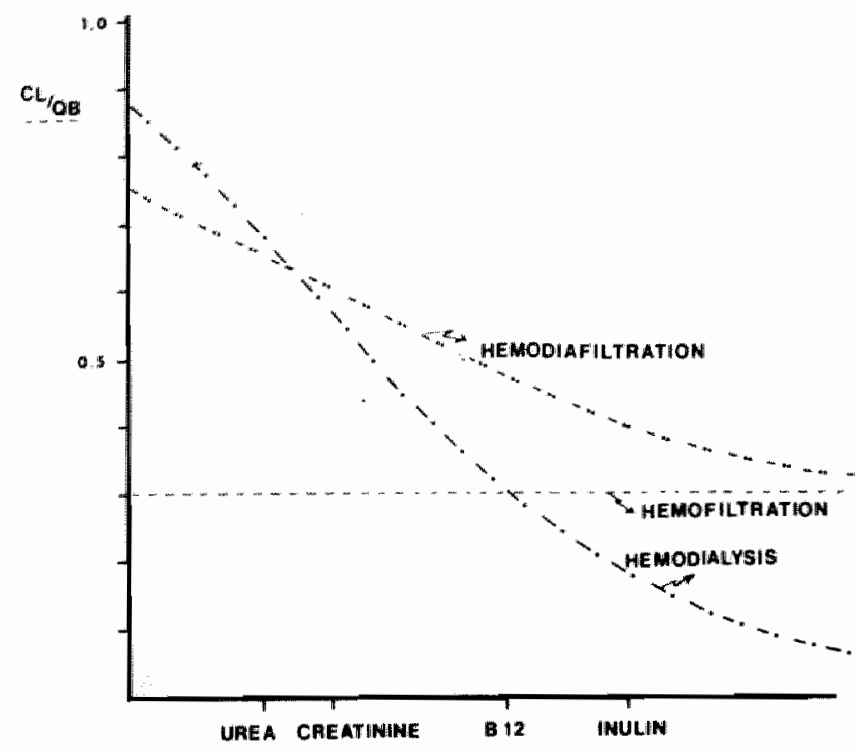

log.

Figure 10 : The predicted relative clearances in hemodiafiltration $\left(Q_{D} / Q_{B}=0.5\right.$ and $\left.Q_{F} / Q_{B}=0.3\right)$, hemodialysis $\left(Q_{D} / Q_{B}=2\right)^{B}$ and hemofiltration $\left(Q_{F} / Q_{B}=0.3\right)$.

course of $1 \frac{1}{2}$ years.

Therefore, other more sensitive criteria should be sought to reveal possible benefits of hemodiafiltration in the long term.

The observed increase in hemoglobin level during hemodiafiltration suggests a possible pathogenetic role for toxic middle molecules in uremic anemia and was also noted by Leber who published the first clinical data on hemadiafiltration in the same period.

Technically hemodiafiltration treatments can only be adequate$1 y$ conducted using equipment that accurately controls fluid ballance. The first step is an isovolumetric pump that ensures precise 
control of the ultrafiltration rate in an open circuit.

Similarly, the second step should be a device that enables exact proportioning of substitution and ultrafiltration rate. Up tilll now this technical problem has been tackled by using microprocessors.

On account of our experiences and the conclusions of the mathematical concept the following requisites for an adequate hemodiafiltration equipment can be formulated :

- The construction must be simple, so that it can be run by all personnel in a routine daily use.

- Technical failures must become visible at a glance and be amenable to prompt correction, making constant supervision by staff members superfluous.

- The financial burden of the purchase must be low.

- The apparatus must be easily accessable to sterilization.

- According to the mathematical concepts the capactty of the apparatus can be restricted to a dialysate volume of 25 liters and a substitution volume of 10 liters.

- This brings the device within the reach of a closed volume circuit, in which control of flluid balance is more easily achieved. 
CHAPTER IV.DESIGN AND PRODUCTION OF A VOLUME CONTROLLED HEMODIAF ILTRATION APPARATUS.

\section{A. Techntoal aspeots}

A hemodiafiltration apparatus that meets the requirements that are formulated in the foregoing chapter is schematically depicted in figure 11 (van Geelen 1979).

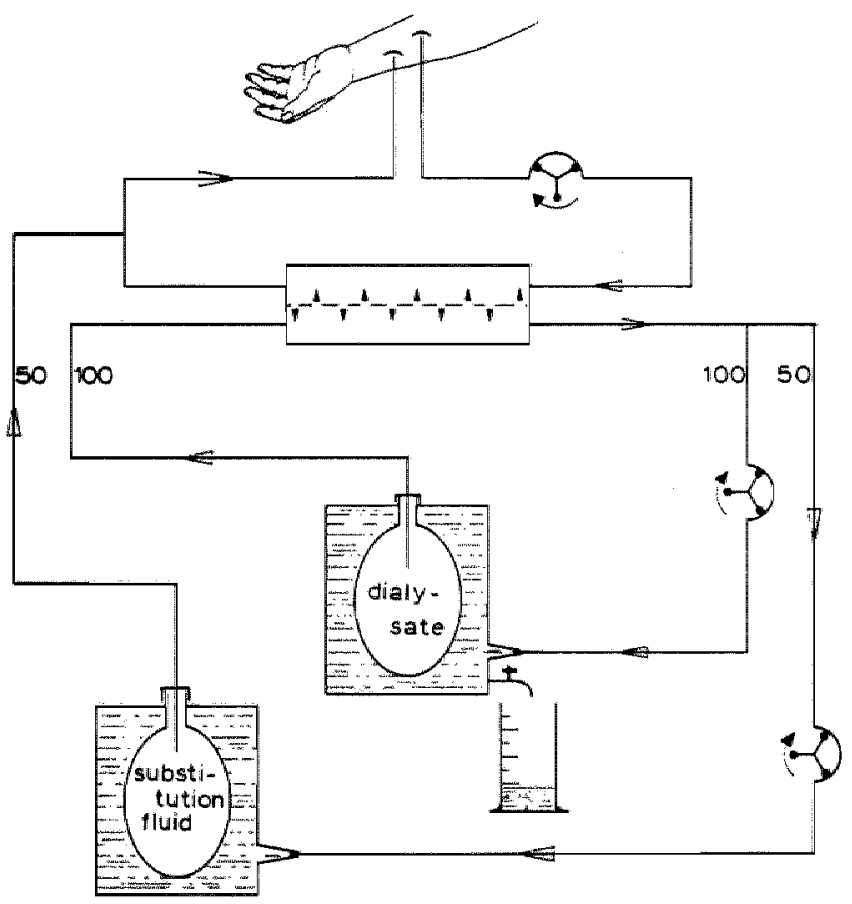

Figure 11 : Schematic illustration of the apparatus that permits simultaneous hemodialysis/hemofiltration (HDF).

It consists of 2 closed circuits; one for hemodialysis and one for 
hemafiltration, connected to each other in a parallel fashion. A flexible and disposable P.V.C. bag containing 20 liters of fresh dialysate, floats in liquid in an airtight closed container of stainless steel.

This dialysate is transported by a rollerpump at a rate of 100 ml/min. through the artificial kidney into the space that surrounds the bag.

This constitutes a single pass diallysis circuit of the closed volume type, in which fluid balance control is easily achieved. At the bottom of the container, there is an outlet through which, during the treatment period, the desired amount of fluid can be gradually withdrawn from the container.

The same principle applies to the hemofiltration circuit. A second rollerpump removes a constant amount of fluid at a rate of $50 \mathrm{ml} / \mathrm{min}$. from the dialysate circuit, thereby creating a negatiwe pressure in the bath compartment of the didyser. This fluid is necessarily replaced by an equal volume transferred from the patients blood through the membrane.

This fluid is transported to the second container and the same amount of fluid will be expelled from the bag in the second container, that is initially filled with a sterile modified Ringer"s lactate solution. This substitution fluid is supplied to the venous air bubbie trap according to the postdilution principle.

As both containers are air-tight closed there will be no net fluid loss firom the patient.

Controlied fluld subtraction from the patient however, can be easily accomplished by gradually tapping from the dialysate container as shown in figure 11 . 


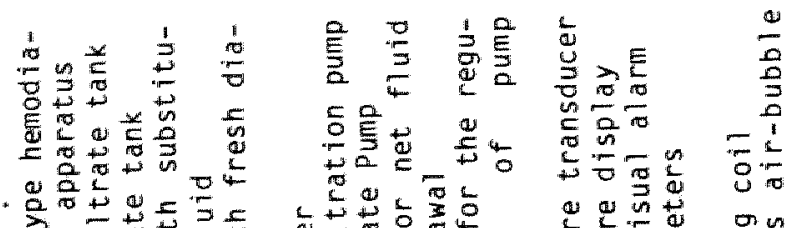

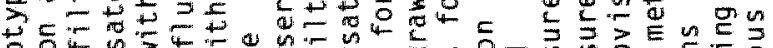
NOO丶万

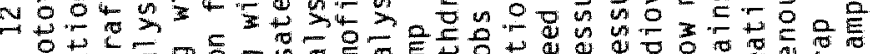

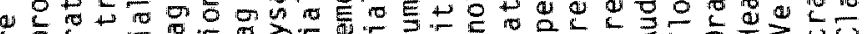

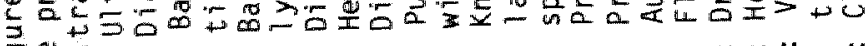

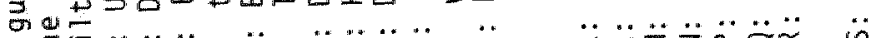

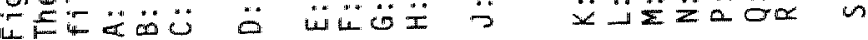

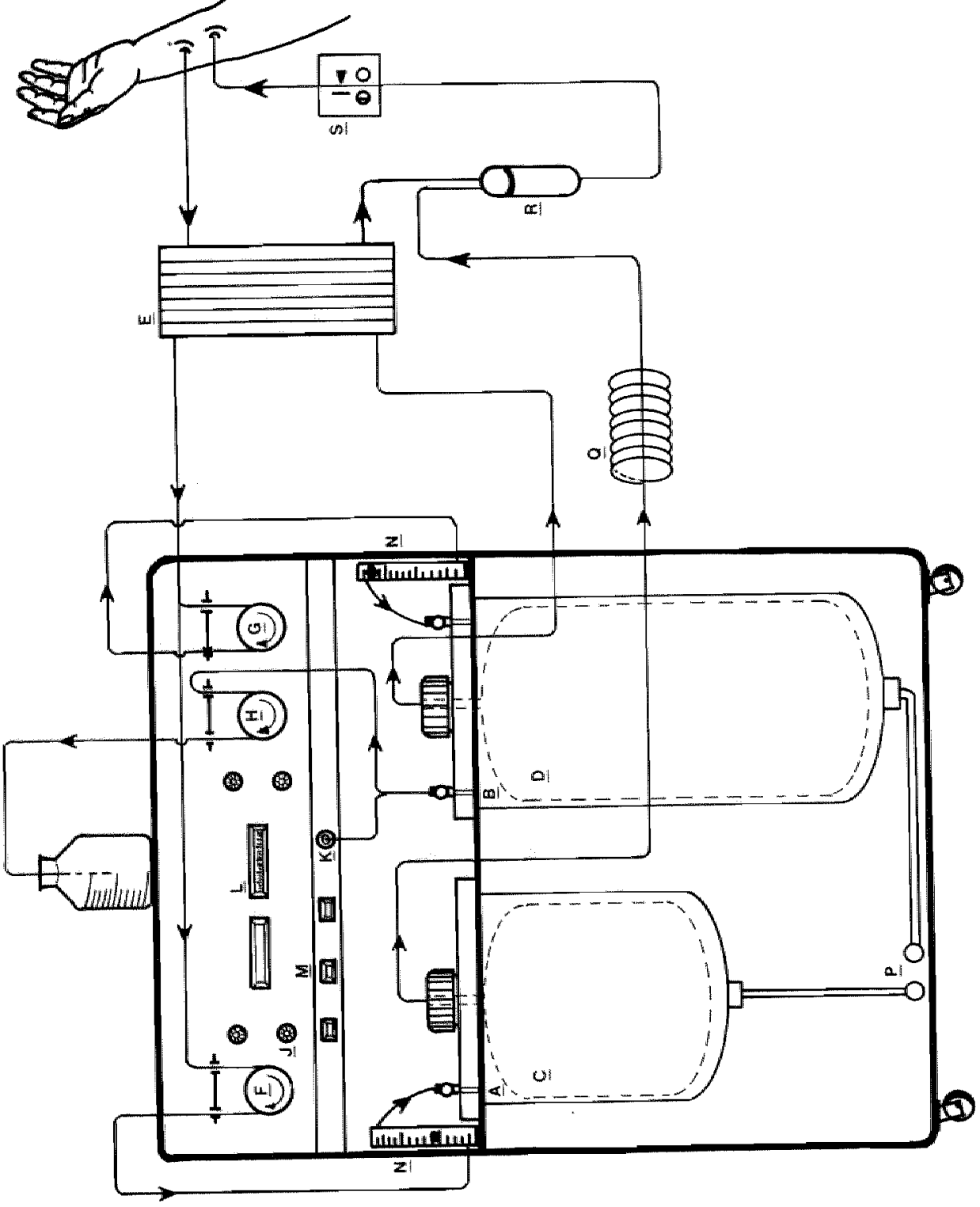


In this procedure high flux dialysers are used and a pressure transalucer connected to the safety valves constantly displays the negative pressure in the circuit, and interrupts the bloodflow when the preset pressure levels are surpassed.

Conventional air and blood leak detectors with audiovisual alarm systems complete the system.

Figure 12 shows the first constructed prototype. In the lower part on the left there is a stainless steel container of 17 liters (A) with in it a P.V.C. bag of 10 liters, filled with substitution fluid (C). On the right side there is a 34 liters container (B) with in it a P.V.C. bag of 20 liters filled with fresh degassed dialysate of $37^{\circ} \mathrm{C} .(\mathrm{D})$. Before the start of the procedure both containers are filled with flutd and the empty disposable sterilized bags are introduced through the central opening at the top. The outflow lines are provided by collars that are firmly sealed to them and become fixed between the screw-caps of the containers, thus establishing air-tight closure of the containers.

Now the bags are filled through the outflowlines that are connected to the dialysate supply respectively infusion bags, and this takes place by emptying the containers through the drain openings at the bottom. Both containers are surrounded by heat isolating material.

In the transparant cover plate of the containers there is a side opening through which wasted dialysate enters the container during the procedure.

The dialysate container has a second opening in the cover-plate for net fluid subtraction out of the patient. 
Through this opening, that is situated in the highest part of the container, any accumulated gas is also pumped out of the system. This opening is also connected to the pressure tranducer $(K)$ located in the top of the apparatus together with all other electronic equipment.

The front screen of the electronic section supports rallerpumps for hemofiltration (F), net Ultrafiltrate subtraction (H) and dialysate transport (G)(from left to right).

Before entering the venous air bubble trap (R) the substitution fluid passes a 2 meter coiled segment that is placed in a thermoregulated chamber to bring it to $38^{\circ} \mathrm{C} .(\mathrm{Q})$.

This prototype is constructed for a hemodiafiltration run of 31 hours with the following operating conditions :

A dialysate flow $\left(Q_{d}\right)$ of $100 \mathrm{ml} / \mathrm{min}$., a net fluid subtraction rate of $\pm 10 \mathrm{mi} / \mathrm{min}$. and a hemofiltration flow $\left(Q_{f}\right)$ of $50 \mathrm{ml} / \mathrm{min}$. It can be used in combination with any high flux dialyser. The measured negative pressure in the dialysate bath for the various membranes is not lower than $-300 \mathrm{~mm} H \mathrm{Hg}$ and the total transmembrane pressure does not exceed $400 \mathrm{mmHg}$, which is in the optimal working range and well below the safety limit for membrane ruptures in these dialysers. Also excessive degassing of the dialysate is avoided.

In the steady state the alarm (S) is activated at pressure fluctuations of $30 \mathrm{mmHg}$ and this represents an adequate automatic safety precaution. 


\section{B. In vitro studies}

Objectives :

Before introducing the constructed prototype into clinical practice in vitro studies were done in order to

- test the technical performance and functional integrity of this closed volume system, especially with regard to fluid balance control.

- To compare the ultrafiltration capacity of various high flux dialysers.

- Test the mathematical concept with clearance measurements.

1. The experimental setup is shown in figure 13.

In this flow bench a measuring glass (N) filled with 5 liters of fresh dialysate replaces the circulating blood volume of the patient. The temperature of this solution is maintained at $37^{\circ} \mathrm{C}$ by placing the measuring glass in a water bassin of $37^{\circ} \mathrm{C} .(0)$.

Representative uremic solutes are added in appropriate concentrations and constant mechanic stirring of the solution takes place (P). The solution is transparted from the reservair to the difalyser by means of a rollerpump (K) and passes through a sensitive Brooks flow meter.

After leaving the dialyser it returns to the reservoir $(N)$.

The hemodiafiltration setup is identical to the described circuit in the prototype.

Final assembly is omitted to be able to manfipulate the connections and to replace single components.

The bags ( $U$ and $T$ ) and the containers ( $A$ and $B$ ) are filled with 


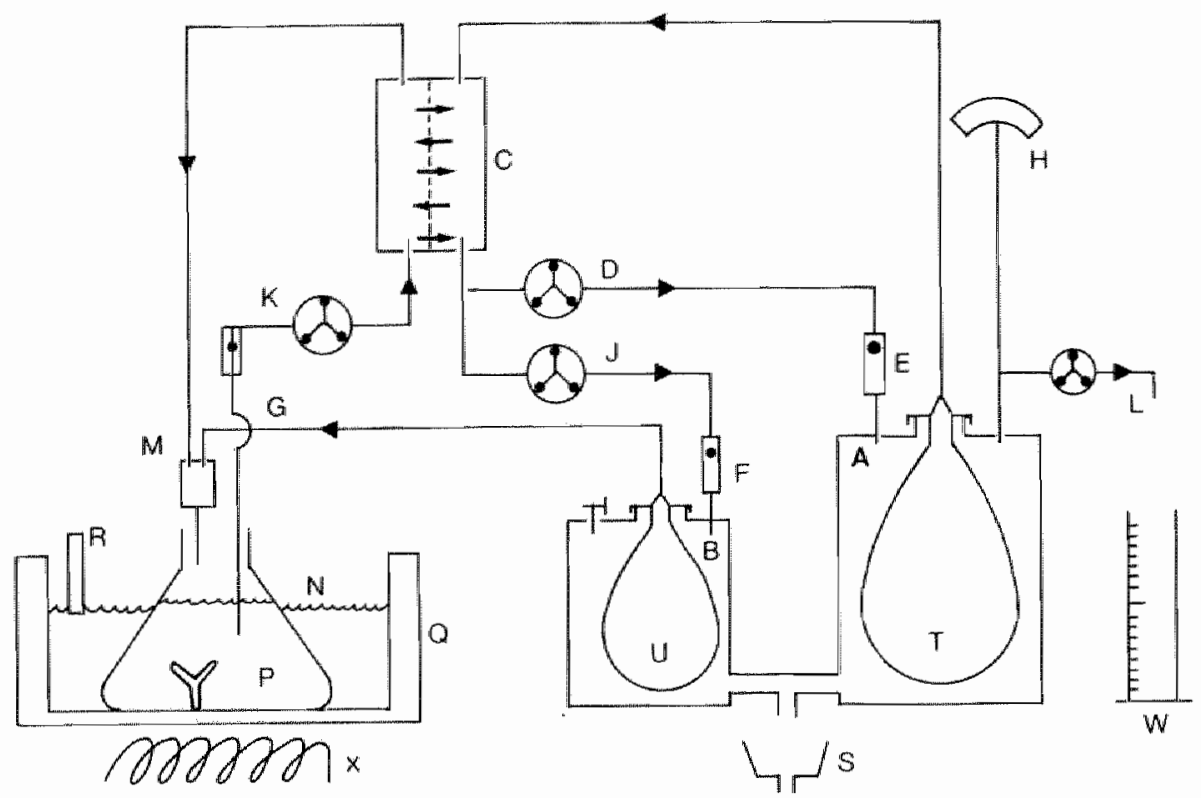

Fingure 13 :

Flow bench for in vitro clearance experiments.

A: Dialysate tank

B: U1trafiltrate tank

$C:$ Dialyser

D: Dialysate pump

E: Dialysate fllow meter

F: Ultrafiltration flow meter

G: Blood flow meter

$H$ : Pressure monitor

$\mathrm{J}$ : Ultrafiltration pump

K: Blood pump

L: Pump for net fluid withdrawa 1

M: Air-bubble trap

$\mathbb{N}:$ : Measuring glass

P. Stirrer

Q: Hot water bassin

R: Thermometer

5: Drain

T: Bag with fresh dialysate

U: Bag with substitution fluid

W: Graduated cylinder

$X$ : Heating source.

fresh dialysate of $37^{\circ} \mathrm{C}$ and they are surrounded by heat isolating material.

2. In the first series of experiments the ultrafiltration capacity of 3 different types of high flux dialysers was measured. The 
characteristics of these 3 commercially available dialysers are sumbrized in table 11 . There is considerable difference in size, construction and composition of the membrane.

\begin{tabular}{|c|c|c|c|}
\hline High Flux Dialyzer & ${ }^{R P} 610$ & $\begin{array}{l}\text { Gambro Lundia } \\
\text { Maior }\end{array}$ & $\begin{array}{l}\text { Cordis Dow } \\
\text { Mode } 1 \text {, } 0\end{array}$ \\
\hline $\begin{array}{l}\text { Membrane Structure } \\
\text { Surface area } \\
\text { Material }\end{array}$ & $\begin{array}{l}\text { plate } \\
1.03 \mathrm{~m}^{2} \\
\text { polyacrylo- } \\
\text { nitrile }\end{array}$ & $\begin{array}{l}\text { plate } \\
1.36 \mathrm{~m}^{2} \\
\text { cupropluane }\end{array}$ & $\begin{array}{l}\text { hollow fibre } \\
2.5 \mathrm{~m}^{2} \\
\text { ce11ulose } \\
\text { acetate }\end{array}$ \\
\hline $\begin{array}{l}\text { Priming volume } \\
\text { Thickness }\end{array}$ & $\begin{array}{l}150 \mathrm{ml} \\
30 \mu \mathrm{m}\end{array}$ & $\begin{array}{l}80 \mathrm{ml} \\
22 \text { 사 } \mathrm{ma}\end{array}$ & $\begin{array}{l}190 \mathrm{ml} \\
60 \mu \mathrm{m}\end{array}$ \\
\hline
\end{tabular}

Table II Physical Characteristics of three High Flux dialyzers.

For these single ultrafiltration measurements the inlet and outlet of the bath compartment of the dialyser were short circuited and led to the ultrafiltrate measuring cylinder through the dialysate pump. The assessment of the ultrafiltration rate as a function of the hydraulic pressure gradient was done in two different ways.

First negative pressure was created in the bath compartment by suction from the dialysate pump.

Secondly positive pressure in the blood compartment was exerted by means of a venous 1 ine clamp. In both methods there was a comparable linear relationship between pressure and ultrafiltration rate as is shown in the figures 14,15 and 16 .

The ultrafitration capacity of the Gambro Lundia and RP610 dialysers were superior to the Cordis Dow high flux dialyser. The variability among different dialysers of the same type was 


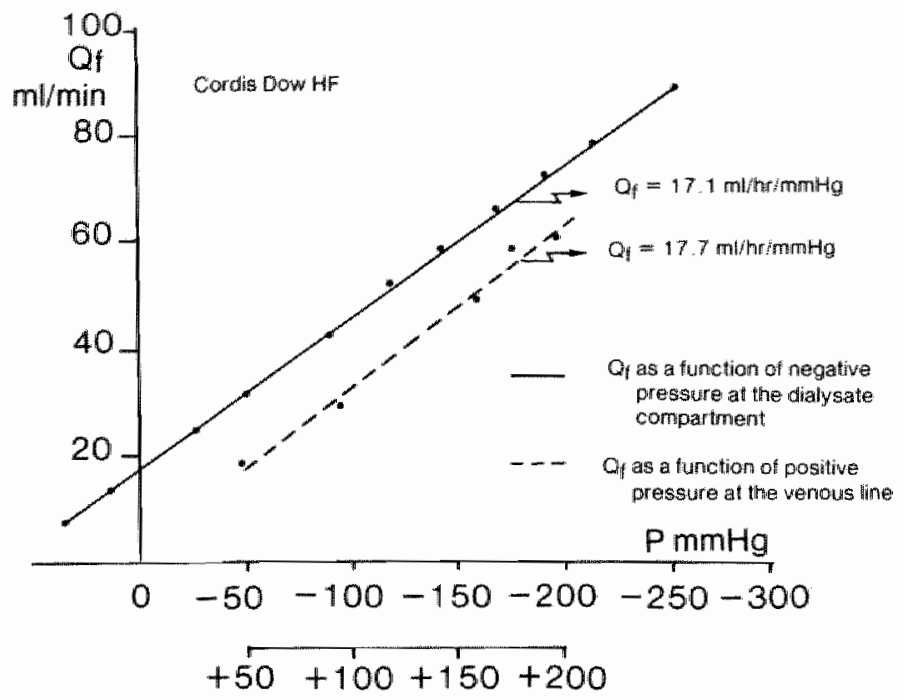

Figure 14 : In vitro wltrafiltration capacity of the Cordis Dow High Flux Dialyser (aqueous solution at $37^{\circ} \mathrm{C}$ ).

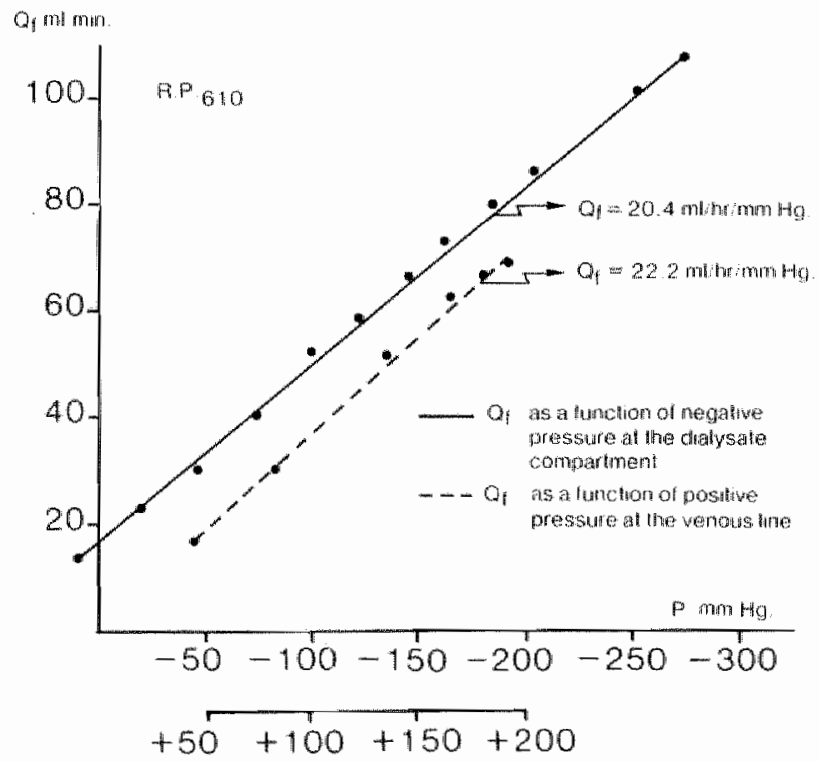

Figure 15 : In vitro ultrafiltration capacity of the R.P. 610 dialyser (aqueous solution at $37^{\circ} \mathrm{C}$ ). 
$Q_{f} \mathrm{ml} / \mathrm{min}$.

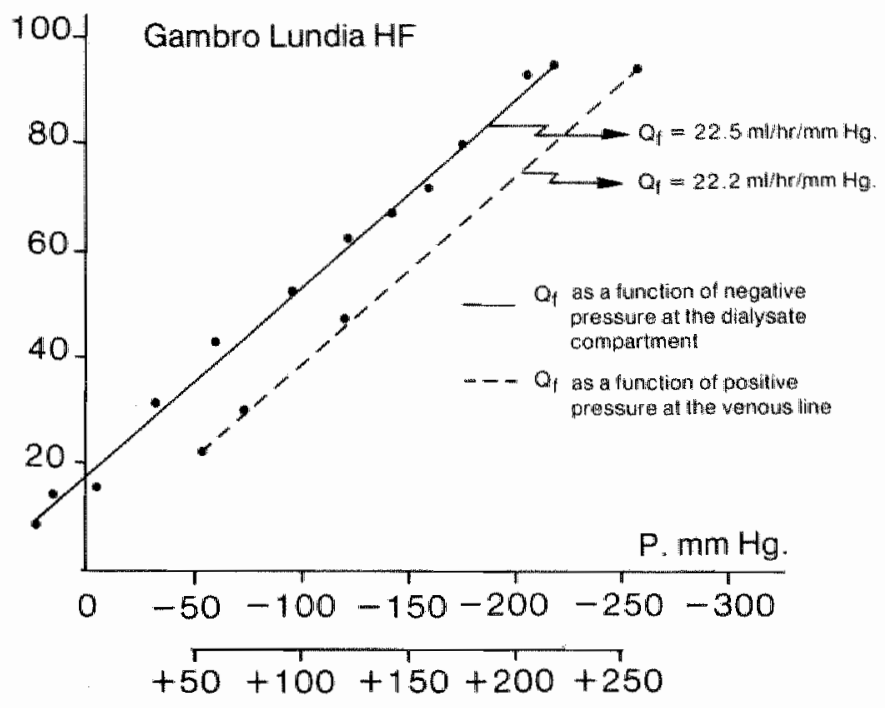

Figure 16 : In vitro ultrafiltration capacity of the Gambro Lundia HF dialyser (aqueous solution at $37^{\circ} \mathrm{C}$ ).

small if they had been stored for a limited period.

Similar ultrafiltration measurements were also conducted in vivo with the RP610 dialyser during the pilot studies, using the isovolumetric ultrafiltration control apparatus in a single pass dialysis ciruit. These results are shown in figure 17 for the first and the last hour of a hemodiafiltration treatment of 4 hours.

On the avarage the ultrafiltration capacity in whole blood is only $50 \%$ of the capacity in an aqueous solution in vitro. The relationship between pressure and ultrafiltration rate is no more linear, but flattens out especially at high transmembrane pressures. 
Also there is a small decrease of ultrafiltration capacity in the course of the treatment.

$Q_{f} \mathrm{ml} / \mathrm{min}$.

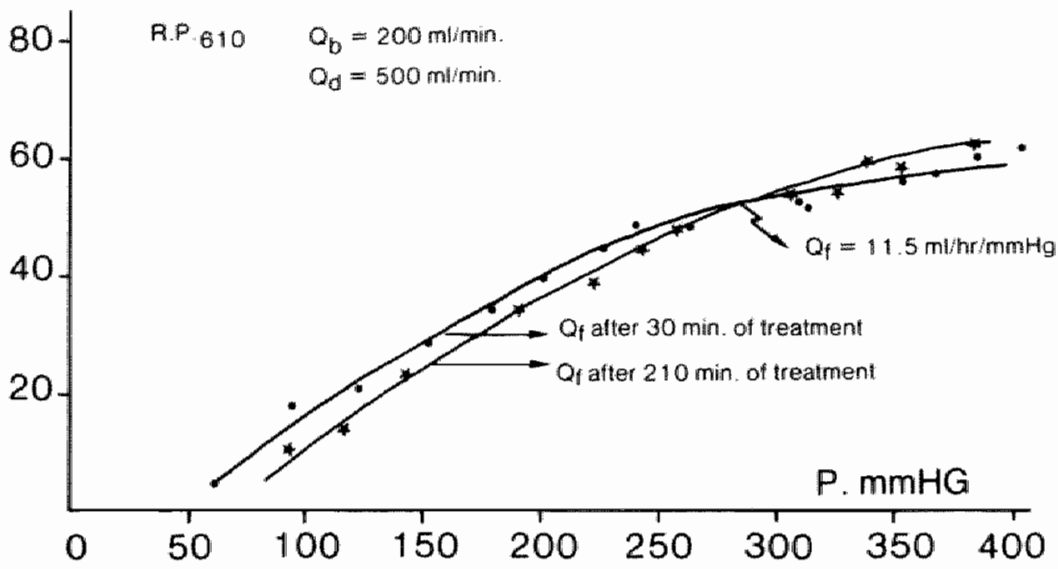

Figure 17 : The in vivo ultrafilltration capacity of the R.P. 610 dialyser at the beginning and the end of a 4 hour treatment.

\begin{tabular}{|c|c|c|c|}
\hline Solute & $\begin{array}{l}\text { Molecular } \\
\text { Weight (Dalton) }\end{array}$ & $\begin{array}{l}\text { Initial } \\
\text { Concentration }\end{array}$ & $\begin{array}{l}\text { Laboratory } \\
\text { Method }\end{array}$ \\
\hline Urea & 60 & 50 mmo $1 / 1$ & $\begin{array}{l}\text { diacetyl monoxime } \\
\text { thiosemicarbazide (Henry) }\end{array}$ \\
\hline Creatinine & 113 & $700 / \mathrm{mol} / 1$ & $\begin{array}{l}\text { Jaffe reaction (cenco } \\
\text { continuous flow system) }\end{array}$ \\
\hline Vit an in & 1355 & $40 \mathrm{mg} / \mathrm{l}$ & spectrofotometer \\
\hline $1{ }^{4} \begin{array}{c}B \\
\text { C-inulin }\end{array}$ & 5000 & 1 acurie/l & $\begin{array}{l}\text { liquid scintillation } \\
\text { counter }\end{array}$ \\
\hline
\end{tabular}

Table III Investigated uremic makkers in in vitro studies

3. In witro clearance measurements.

To the 5 liters of dialysate solution in the measuring-glass, 
urea, creatinine, witamin B12 and inulin were added.

The initial comcentration and the laboratory methods are given in table III.

During a steady state procedure there will be an exponential decrease in concentration according to the following expression:

$c_{t}=c_{0} \cdot e^{-\frac{C_{1}}{V} t}$, where

$c_{0}=$ initial concentration

$c_{t}=$ concentration after $t$ minutes

$V=$ volume of the reserwoir

C1 $=$ clearance

From this expression clearance can be calculated :

$C 1=\frac{V}{t} \ln \frac{C o}{C t}$

In each experiment steady state was controlled during 40 minutes and concentrations of samples from the reservoir were measured at 10 minute intervals.

The warious flows and the fluid balance were camefully observed, and significant fluctuatians did not occur.

Thus the decrease of the concentration, plotted on a semi-lagaritmic scale, is represented by a straight line, from which the average clearance was calculated (figure 18).

This method of clearance calculation is preferred because it is in the same way applicable to hemodiafiltration and hemodialysis simulations.

Clearance calculations from the concentration difference in arterial and venous line and the momentarily measured blood flow are 


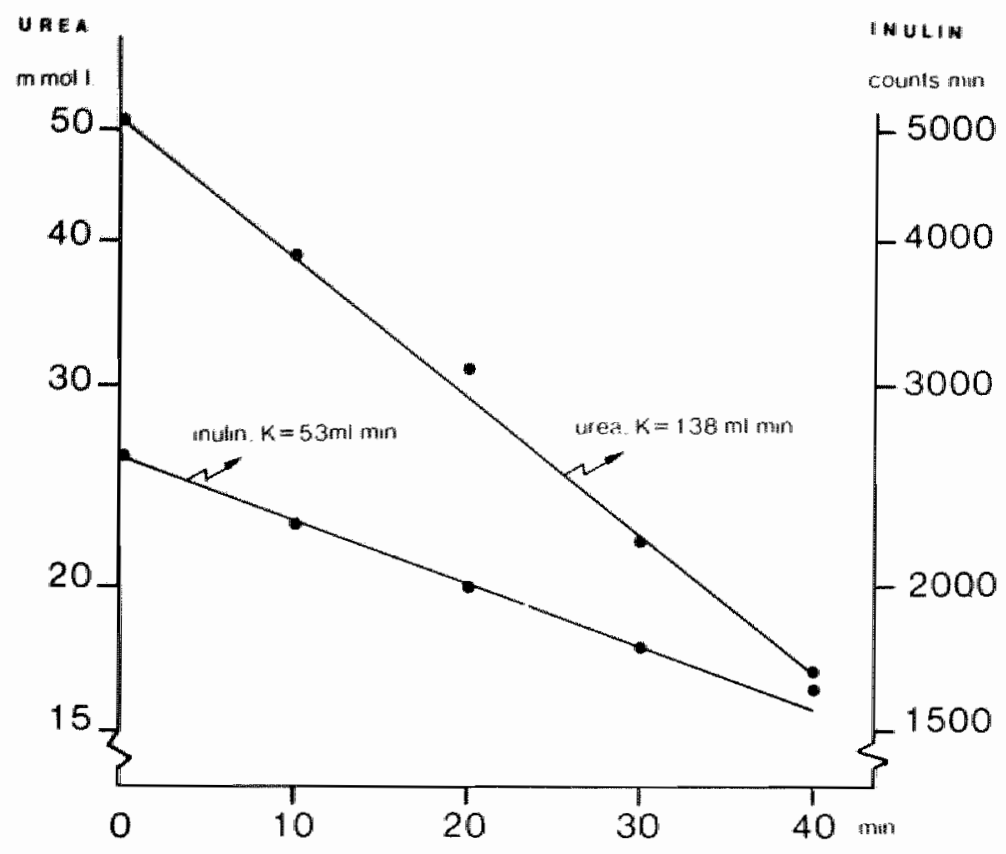

Figure 18 : Fall of the concentration of urea and inulin in the measuring glass during a representative 40 minutes in vitro experiment, from which the mean clearances are calculated.

unreliable in the presence of significant ultrafiltration and easilly disturbed by brief fluctuations.

These 40 minutes experiments were repeated several times using different dialysers of each of the 3 types.

$\mathrm{Q}_{\mathrm{b}}$ was kept at $150 \mathrm{ml} / \mathrm{min}$. during all experiments. Net fluid subtraction was not applied.

During hemodiafiltration the ultrafiltration $\left(Q_{f}\right)$ and substitution flow $\left(Q_{5}\right)$ were fixed at $50 \mathrm{ml} / \mathrm{min}$.

6 different treatment strategies were investigated, being HD 
at $Q_{d}=100, Q_{d}=200$ and $Q_{d}=500$ and $\mathrm{HDF}$ at $Q_{d}=100, Q_{d}=200$ and $Q_{d}=500 \mathrm{ml} / \mathrm{min}$.

Table IV shows the results with Cordis Dow high flux dialysers with in the left column the measured clearances during $H D$ and in the right column the measured clearances during HDF.

Tables $V$ and $V I$ show the results with RP610 dialysers and the Gambro Lundia high flux dialysers.

\begin{tabular}{|c|c|c|c|}
\hline $\begin{array}{l}\text { Cordis Dow } H F \\
N=3 * \\
Q_{b}=150 \mathrm{ml} / \mathrm{min} .\end{array}$ & $\begin{array}{l}\text { Clearances and } \\
\text { Hemodialysis } \\
a_{f}=0\end{array}$ & $\begin{array}{l}\text { standard deviation } \\
\text { Hemodiafiltration } \\
\mathrm{q}_{\mathrm{f}}=50 \mathrm{ml} / \mathrm{min} .\end{array}$ & * \\
\hline $\begin{array}{l}\text { urea } \\
\text { creatinine } \\
\text { vitamin } B \quad 12\end{array}$ & $\begin{array}{r}102 \\
80 \\
49 \\
49\end{array}$ & $\begin{aligned} 105 & (10) \\
101 & (5) \\
73 & (9)\end{aligned}$ & $Q_{d}=100 \mathrm{ml} / \mathrm{min}$. \\
\hline $\begin{array}{l}\text { urea } \\
\text { creatinine } \\
\text { vitamin B } 12\end{array}$ & $\begin{array}{rr}115 & (10) \\
101 & (9) \\
54 & (10)\end{array}$ & 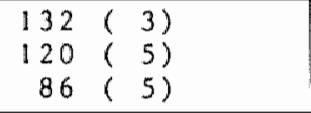 & $\mathrm{a}_{\mathrm{d}}=200 \mathrm{~m} 1 / \mathrm{min}$ \\
\hline $\begin{array}{l}\text { urea } \\
\text { creatinine } \\
\text { vitamin } B \quad 12\end{array}$ & $\begin{array}{r}129(8) \\
113(10) \\
65(8)\end{array}$ & 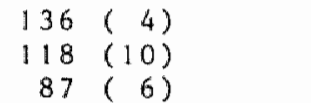 & $Q_{d}=500 \mathrm{~m} 1 / \mathrm{min}$. \\
\hline
\end{tabular}

* different dialyzers were tested in each treatment strategy

Table IV In vitro clearances (ml/min.) of the Cordis Dow High Flux dialyze in $H D$ and $H D F$ at various dialysate flows.

As expected vitamin B12 clearances were much higher during HDf. It can also be seen that during HDF with a low dialysate flow of $100 \mathrm{mil} / \mathrm{min}$. Clearances of small solutes are only slight ly lower than during conventional $H D$ with $Q_{d}$ of 500 ml/min.

Therefore these 2 strategies were compared in an additional series of experiments conducted with the same dialyser. The results are shown in table VII. HD $\left(Q_{d}=500\right)$ was etther preceeded or followed by HDF $\left(Q_{d}=100\right)$. Three dialysers of each type were investigated, and the mean clearance values are given. Repetitive measurements 


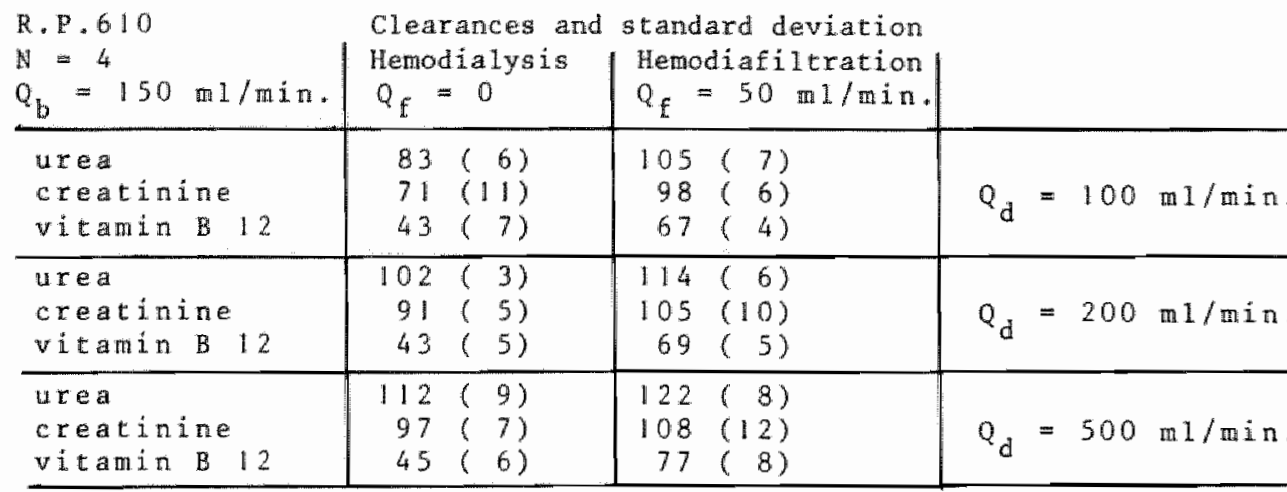

Table V In vitro clearances (mi/min.) of the R.P.610 dialyzer in HD and HDF at various dialysate flows.

Gambro Lundia Maior He

\begin{tabular}{|c|c|c|c|}
\hline $\begin{array}{l}N=1 \\
Q_{b}=150 \mathrm{~m} 1 / \mathrm{min} .\end{array}$ & $\begin{array}{l}\text { Hemodialysis } \\
Q_{f}=0\end{array}$ & $\begin{array}{l}\text { Hemodiafiltration } \\
q_{f}=50 \mathrm{~m} 1 / \mathrm{min} .\end{array}$ & \\
\hline $\begin{array}{l}\text { wrea } \\
\text { creatinine } \\
\text { vitamin B } 12\end{array}$ & $\begin{array}{l}96 \\
78 \\
41\end{array}$ & $\begin{array}{r}119 \\
107 \\
73\end{array}$ & $Q_{d}=100 \mathrm{~m} / \mathrm{min}$. \\
\hline $\begin{array}{l}\text { urea } \\
\text { creatinine } \\
\text { vitamin B } 12\end{array}$ & $\begin{array}{r}115 \\
94 \\
43\end{array}$ & $\begin{array}{r}130 \\
116 \\
78\end{array}$ & $\mathrm{q}_{\mathrm{d}}=200 \mathrm{~m} 1 / \mathrm{min}$ \\
\hline $\begin{array}{l}\text { urea } \\
\text { creatinitae } \\
\text { vitamin B } 12\end{array}$ & $\begin{array}{r}128 \\
106 \\
44\end{array}$ & $\begin{array}{r}141 \\
127 \\
83\end{array}$ & $Q_{\mathrm{d}}=500 \mathrm{mi} / \mathrm{min}$. \\
\hline
\end{tabular}

Table VI In vitro clearances (m1/min) of the Gambro Lundia Maior High Flur dialyzer in HD and HDF at various dialysate flows.

were done wh the Cordis Dow dialyser to define the confidence limits and in these measurements ${ }^{14} \mathrm{C}$ inuline was included as well. These data were fitted to the theoretical curves which is shown in figure 19.

There is good agreement between the predicted and measured 
Clearances (mean)

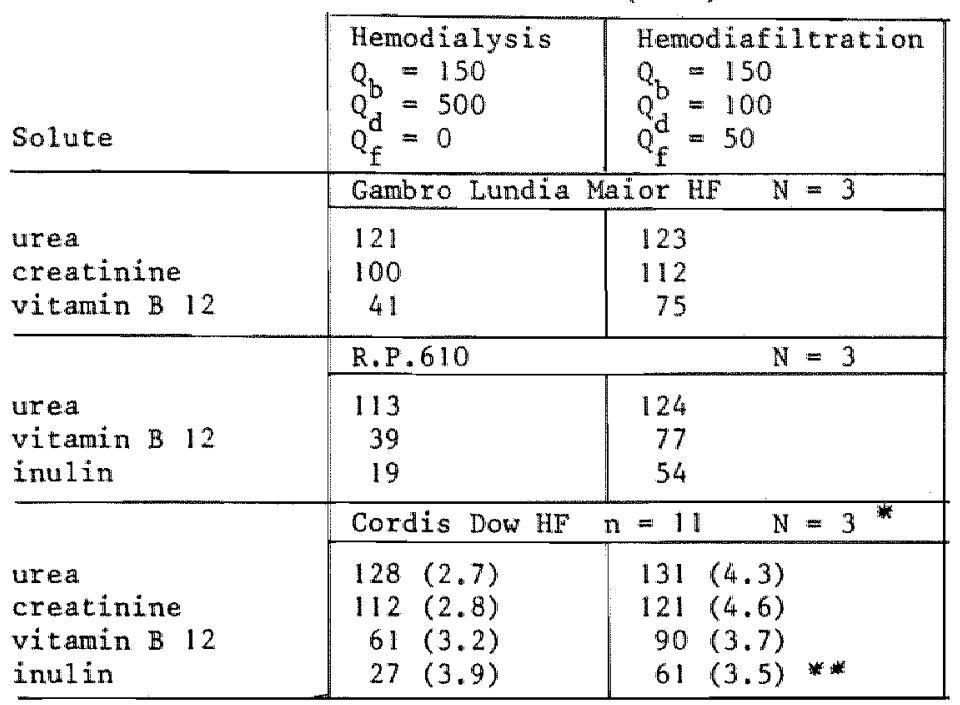

* $N$ number of dialyzers used

$\mathrm{n}=$ number of experiments

** $95 \%$ confidence limits between brackets.

Table VII In vitro clearances of HD and HDF, sequentially performed in the same dialyzer.

values. However inuline clearances are lower than predicted both in HD and HDF, which is due to the fact the passage of larger molecules is partially hindered by the pore size of this membrane. This membrane property is usually called sieving coefficient, and is defined by the ratio of the concentration of that solute in the ultrafiltrate and retentate. This membrane property was not considered in our mathematical concept.

In in vivo conditions pore size totally restricts passage of proteins and corpuscular elements of blood. The build up of a layer of concentrated protein at the membrane surface, especially in the presence of a high ultrafiltration flux, will reduce the 


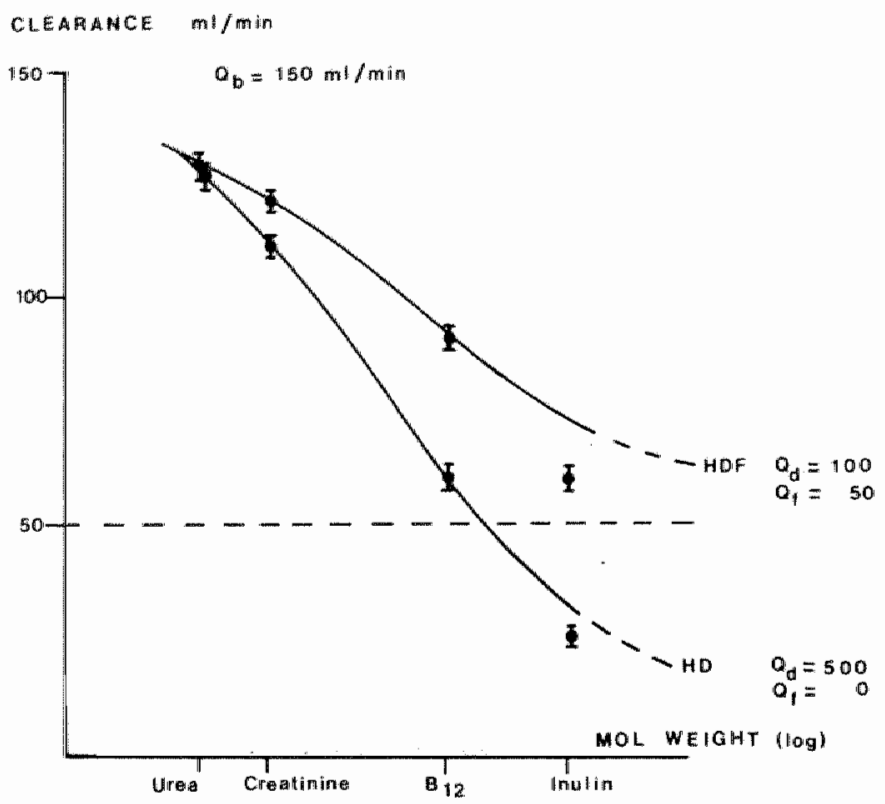

Figure 19 : The in vitro clearances of the Cordis Dow dialyser with the $95 \%$ confidence limits and the theoretical expectancy.

solute flux through the membrane and to a lesser degree the volume flux (Spiegler and Kadem 1966, Jaffrin 1978, 1979, 1981, Klein 1978, Villaroet 1977).

So, clearance studies of a protein containing solution in witro can be expected to yield lower vallues than from an aqueous solution.

Therefore some additional experiments were carried out with 5 liters of human plasma with a protein content of $45 \mathrm{gr} / \mathrm{l}$. 


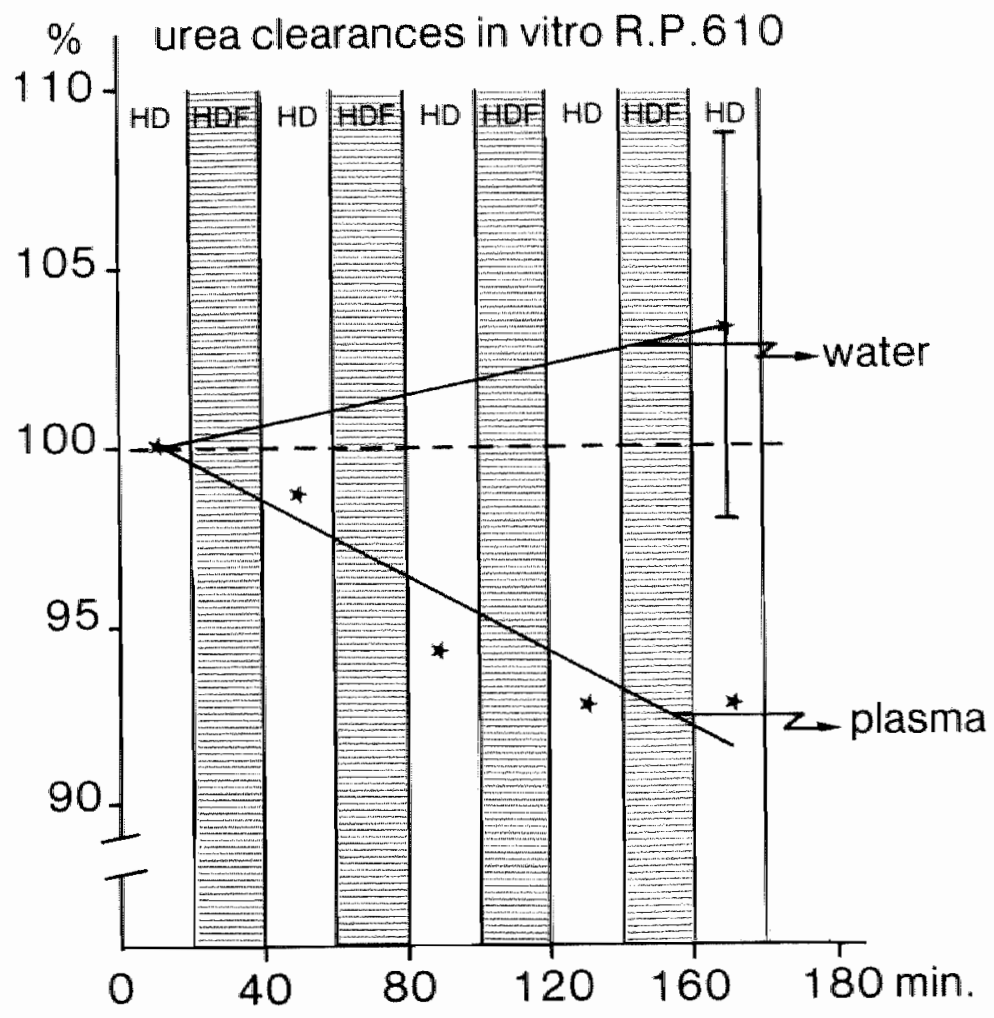

Figlure 20 : Decrease of the R.P. 610 dialyser performance during alternating $H D$ and HDF procedures in a plasma containing solution (mean $\#$ SO).

Heparin was administered at the venous line by continuous infusion up to $20.000 \mathrm{U}$ in 3 hours. The temperature was kept at $37^{\circ} \mathrm{C}$. and there was continuous mechanical stirring.

Urea was added to a concentration of $40 \mathrm{mmol} / \mathrm{l}$ at the beginning of each clearance period. HD was alternated with MDF at 20 minute intervals. During HDF TMP was kept at $-300 \mathrm{mnHg}$ and $Q_{f}$ was \pm 70 $\mathrm{ml} / \mathrm{min}$. $Q_{d}$ was $500 \mathrm{ml} / \mathrm{min}$. and $Q_{b}$ was $200 \mathrm{ml} / \mathrm{min}$.

In an RP610 dialyser there was a $10 \%$ decrease of urea clearance 
after 4 HDF perliods and this was not seen in aqueous solution in another RP610 dialyser that served as control (figure 20 ).

Clearances were calculated in plasma water. However reproducebility of these experiments was low and they were considered to be of limited walue. 
Performance of hemodiafiltration treatments is possible with relatively simple equipment that garantees exact fluid ballance contral. This can be done by the construction of a double clased circuit formed by two containers in which flexible bags are suspended.

Thus, inclusion of expensive electronic monitoring devices is avoided and this brings the apparatus in the scope of routime use with modern high flux dialysers.

Three different, commercially avallable high flux dialysers were compared in in vitro studies and there was no big difference in ultrafiltration capacity and dialysance during HDF procedures.

In an aqueous solution the in vitro clearances of uremic solutes correspond to the mathematical prediction and during HDF clearance of middle molecules is much higher than during $h D$.

Also, with respect to small molecules the dialysate flow can be reduced from 500 to $100 \mathrm{ml} / \mathrm{min}$. in HDF to yield sufficlent clearances.

Therefore the capacity of the closed circuit can be restricted to 20 liters of dialysate and 10 liters of substitution fluid for a $3 \frac{1}{2}$ hours HDF treatment.

However the absolute values for clearance and ultrafiltration rate in vitro in an aqueous solution overestimate the in vivo performance in whole blood.

In vivo the ultrafiltration capacity of the RP610 dialyser was reduced by almost $50 \%$, as is shown in figure 17 . 
Also, in the presence of protein, there is a progressive reduction in diffusive and convective mass transport through the membrane due to protein coating. These adverse effects must be evaluated by in wivo clearance studies. 


\section{A. Technical aspects and cross-over study}

Clinical experience with the prototype apparatus was first gathered in 6 selected patients who consented to undergo HDF treatment during 3 successive weeks. They were informed by word and given extensive explanation in writing. There was no special indication for HDF treatments in any of them. HDF treatments (31 hours) during 3 successive weeks were followed ( 3 patients) or preceeded ( 3 patients) by conventional HD treatments ( 4 hours) during 3 successive weeks. Onty RP610 dialysers were used. During the 6 weeks observation period there was permanent supervision by one of the investigators. The patients served as their own contral. $Q_{b}$ was kept at $200 \mathrm{ml} / \mathrm{min}$., measured by air-bubble displacement in a 1 meter race-track in horizontal position. In $H D, Q_{d}$ was $500 \mathrm{ml} / \mathrm{min}$. and in HDF $Q_{d}$ was $100 \mathrm{ml} / \mathrm{min}$. (Brooks flow meter). During HDF $Q_{f}$ was kept at 50 to $60 \mathrm{ml} / \mathrm{min}$. and during HD $Q_{f}$ was kept at 0 to $10 \mathrm{ml} / \mathrm{min}$, depending on the desired net body weight reduction and measured by collection in a graduated cylinder. 47 HDF treatments were evaluated. Electronic bed-scales were not used and fluid balance was evaluated by measuring body weight before and after treatment on a calibrated mechanical balance. Body weight reduction was always attained with an accuracy of 100 grams.

Within 15 minutes after the start of treatment steady state conditions were selected to ensure a gradual weight reduction and emptying of the dialysate and substitution bags within 3 a hours. 
During this period the negative pressure registered in the dialysate container was about $-250 \mathrm{~mm} / \mathrm{Hg}$. and did not show fluctuations indicating unimpeded enptying of the bags. Usually a sllight increment of negative pressure was obserwed towards the end of the procedure, being at most $50 \mathrm{mmHg}$. At the end of the procedure, complete mptying of one of the bags always caused a sudden pressure drop that activated the alam and interrupted the circulation automatically.

The amount of gas produced by the negative pressure was small, indicating that there were no leaks at the connections and this gas was effectively removed from the system together with the excess of fluid removed to obtain weight reduction. Consequentily there was ro disturbance of fluid balance. The conventional $H O$ treatments were carried out with the isovolumetric ultrafiltration pump, described in the second chapter to obtain the same degree of accuracy of fluid removal during HD as during HDF. This was necessary for the adequate comparison of blood pressure behaviour in both procedures.

The most relevant clinical data of these 6 patients are shown in table VIII. The mean age was 54 years (range 27 to 71 ), and there were 3 male and 3 female patients. 5 out of 6 patients had been treated by conventional HD with hollow-fibre dialysers (0rganon Technica) for a mean duration of 4.8 years (range 0.5 to 9 years). Patient C.V. was included in the study at the moment his end stage remal failure required artificial kidney treatment. All other patients switched to RP610 dialysers 6 months prior to the cross-over study $(3 \times 4$ hours $)$.

Renal failure was caused by chronic pyelonephritis in 3 


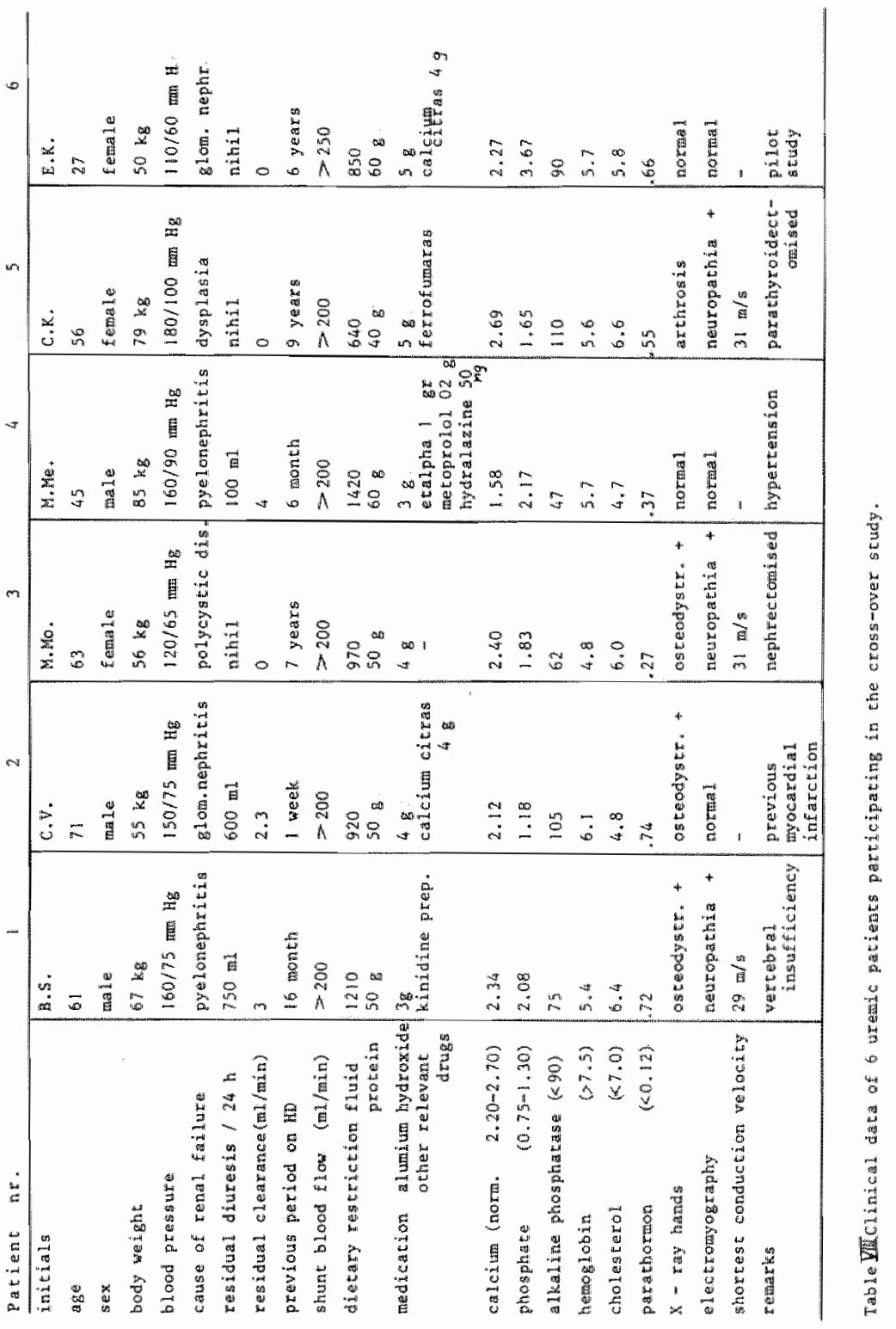


patients, chronic glomerulonephritis in 2 patients, and 1 patient suffered from polycystic disease. The residual glomerular filtration rate was lless than $3 \mathrm{~m} / \mathrm{min}$. In all patients except for pattent M.Me. Patient M. Mo underwent billateral nephrectomy and patient E.K. had her right kidney removed 5 years prior to the study. Two patients (B.S. and C.V.) were not subjected to fluid restriction as they had sufficient residual diurests. All other patients were urged to restrict their dafly free fluid intake to $500 \mathrm{ml}$. Further dietary prescriptions included a protein intake of $1 \mathrm{~g} / \mathrm{kg} /$ day, a potassium intake of 1920 to $3400 \mathrm{mg} /$ day and a sodium intake of $500 \mathrm{mg} / \mathrm{day}(22 \mathrm{mmol} / \mathrm{day})$.

All patients used phosphate binding drugs and displayed a two to sixfold increase in their parathormon levels, in 3 of them secondary hyperparathyroidism being clinically manifest. Patient C.K. underwent subtotal parathyroidectomy 2 years prior to study but parathormon levels remained high.

Uremic polyneuropathy was clinically manifest in 3 patients: B.S., M.Mo. and C.K.

Significant hypertriglyceridemia did not exist among the studied patients.

Blood pressure changes in relation to body weight reduction in the 6 patients are shown in figure 21 . The mean values and standard deviations of the systolic, diastolic and mean arterial pressure before and after treatment are given. Statistical analysis was done by means of student"s t test.

There are no significant differences for these values between HD and HDF. However, the course of the blood pressure during one treatment session was considerably more stable in HDF than in $H D$, 


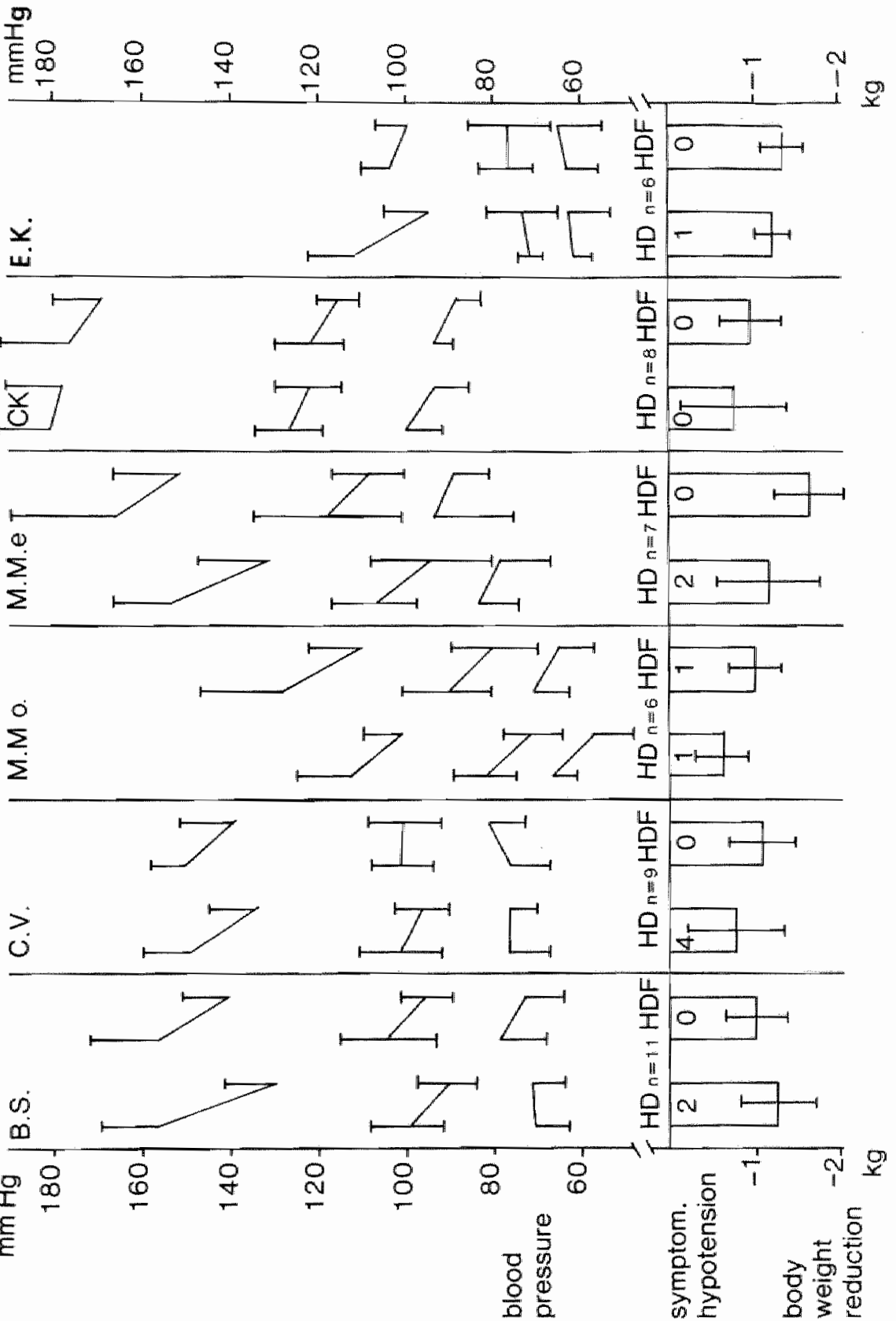

Figure 21 : Blood pressure behaviour, body weight changes and incidence of symptomatic hypotension in $\mathrm{HD}$ and $\mathrm{HDF}$ in 6 patients during 6 weeks of observation. (systolic, diastolic and mean blaod pressure before and after each treatment: mean \pm SD). 
and in only one HOF treatment, which is significantly less $p<$ 0.01). The mean reduction of body weight in all treatments was 1056 grams (SD 270 grams); in HDF 1075 grams and in HD 1036 grams.

It should be noted that fluid withdrawal was always about $50 \%$ more, as the patients were allowed to ingest 500 grams of food and drinks during the treatment. In the literature (wizemann 1981), the overall incidence of symptomatic hypotension during $H D$ is estimated to be 25-30\%. Symptomatic hypotension was defined as a blood pressure drop of more than $20 \%$ requiring therapeutic intervention. Saline infusions to treat symptomatic hypotension have not been used, and have in general become a rarity since the introduction of the isovolumetric ultrafiltration pump for single pass HD treatments. This might be due to the more linear decline of body weight during treatment and the gradual onset of hypotension which enables the patient to stop ultrafiltration in time and take a temporary Trendelenburg position. In the past, severely owerhydrated patients and those who badly adhered to their fluid restriction, requiring more than 2 liters of fluid removal, were treated by sequential ultrafiltration/memodialysis according to Bergstrom's suggestion. This also applied to patient M.Me.

Several months before the study he had to be haspitalized because of severe fluid overload and hypertension with diastolic pressures above $140 \mathrm{mmHg}$ and grade III hypertensive retinopathy. In the next 3 HD treatments body weight was reduced with $4 \mathrm{~kg}$ by Bergström's method and he recileved beta-blocking drugs and hydralazine after which his blood pressure became normal. During the study period his blood pressure was acceptable but in the intra- 
dialytic days his body weight sometimes increased up to $2 \mathrm{~kg}$ beause of bad compliance to his regimen. During the Hof treatments fluid could always be withdrawn without problems up to $2 \frac{1}{2}$ liters in $3 \frac{1}{2}$ hours. During HD treatments however hypotensive episodes were provoked by $1 \frac{1}{2}$ liters of fluid withdrawal in 4 hours.

On the other hand fluid withdrawal in patient E.K. was usually associated with muscle cramps and nausea, while her blood pressure was habitually low but rather stable. Treatment tolerance improved considerably during HDF and this led to a $1 \mathrm{~kg}$ reduction of her supposed and so called dry bady weight. Good treatment tolerance was al so the main reason for her participation in the pillot study.

\begin{tabular}{|c|c|c|c|c|c|c|c|}
\hline \multirow[b]{2}{*}{ Solute } & \multirow[b]{2}{*}{$\mathrm{n}$} & \multicolumn{2}{|c|}{$\begin{array}{l}\mathrm{HD} \quad(4 \text { hours }) \\
\mathrm{Q}_{\mathrm{d}}=500 \mathrm{ml} / \mathrm{min} . \\
\mathrm{Q}_{\mathrm{b}}=200 \mathrm{ml} / \mathrm{min} . \\
\mathrm{Q}_{\mathrm{f}}=10 \mathrm{ml} / \mathrm{min} .\end{array}$} & \multicolumn{4}{|c|}{$\begin{array}{l}\mathrm{HDF} \quad\left(3 \frac{1}{2} \text { hours }\right) \\
\mathrm{q}_{\mathrm{d}}=100 \mathrm{mI} / \mathrm{min} . \\
\mathrm{Q}_{\mathrm{b}}=200 \mathrm{mi} / \mathrm{min} . \\
\mathrm{q}_{\mathrm{f}}=60 \mathrm{mI} / \mathrm{min} .\end{array}$} \\
\hline & & pre & post & pre & & post & \\
\hline urea & 20 & $30.2 \quad(6.5)$ & $15.8(4.6)$ & 33.1 & $(3.8)$ & 19.7 & $(3.7)$ \\
\hline creatinine & 17 & $1563 \quad(197)$ & $807 \quad(163)$ & 1528 & $(135)$ & 896 & $(\| 100)$ \\
\hline urate & 10 & $0.47(0.05)$ & $0.20 \quad(0.05)$ & 0.51 & $(0.05)$ & 0.22 & $(0.06)$ \\
\hline phosphate & 16 & $2.17(0.78)$ & $1.28(0.41)$ & 2.20 & $(0.45)$ & 1.26 & $(0.21)$ \\
\hline calcium & 8 & $2.52(0.12)$ & $2.61(0.11)$ & 2.49 & $(0.16)$ & 2.60 & $(0.13)$ \\
\hline potassium & 16 & $4.7 \quad(0.7)$ & $3.6 \quad(0.4)$ & 4.7 & $(0.7)$ & 3.7 & $(0.6)$ \\
\hline bicarbonate & 15 & $18.4 \quad(1.7)$ & $19.8 \quad(2.0)$ & 18.8 & $(1.6)$ & 18.8 & $(1.6)$ \\
\hline sodium & 16 & $136 \quad(3.6)$ & $(3.0)$ & 134 & $(3.9)$ & 133 & $(4,1)$ \\
\hline
\end{tabular}

Table IX Solute concentrations before and after HD and HDF (mean and standard deviations)

Although the removal of small molecular solutes was in the same range for both procedures in vitro, the hour reduction of the treatment time in HDF should be taken into account. Blood samples were drawn before and after treatment to measure serum 


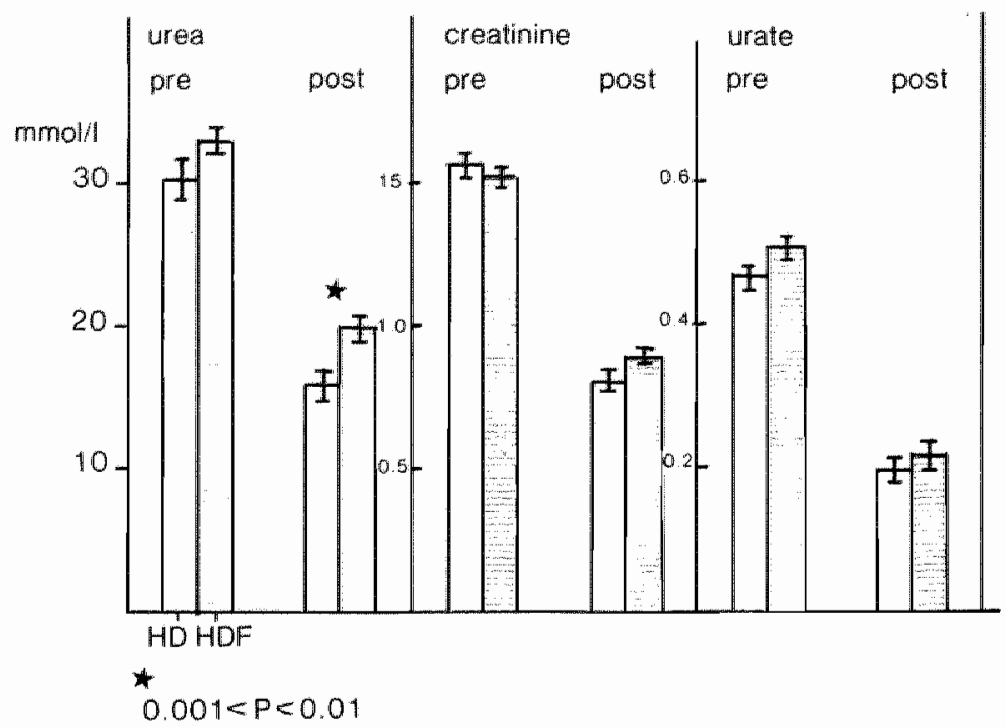

Figure 22 : Mean plasma concentrations of urea, creatinine and urate before and after HD and HDF treatments in 6 patients during 6 weeks of observation (mean \pm 2 S.E.M.).

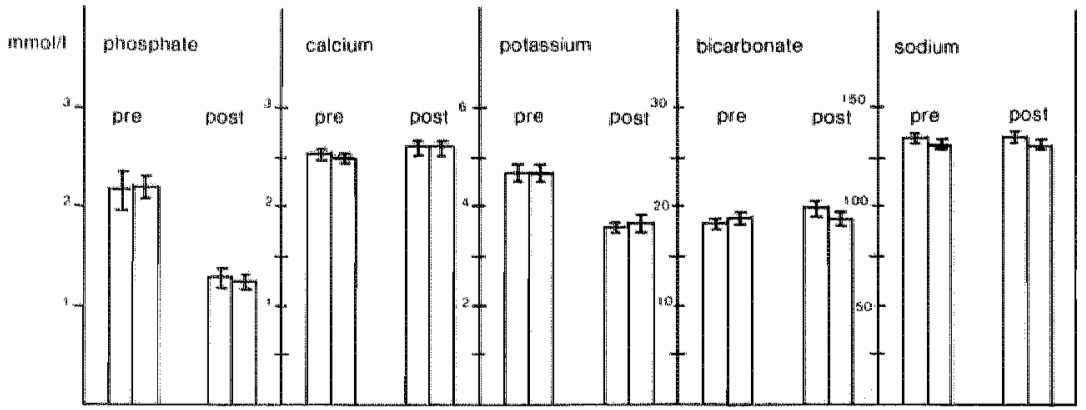

Figure 23 : Mean plasma concentrations of phosphate, calcium, potassium, bicarbonate, and sodium before and after HD and HDF treatments in 6 patients during 6 weeks of observation (mean \pm 2 S.E.M.). 
concentrations of urea, creatinine, urate, phosphate, and electrolytes. The mean walues and standard errors are given in table IX and figures 22 and 23. Statistical inference was done by means of student's t test on unpared data. There were no statistically significant differences except for the post treatment urea values that were higher in HDF. The lower urea extraction in HDF became particularly apparent in the heaviest patient M.Me., whose serum concentrations before and after treatment are shown in figure 24 for 5 consecutive HD and HDF sessions. (The urea values of patient C.V. are not included because of the changing state of protein katabolism at initiation of dialyser treatment).

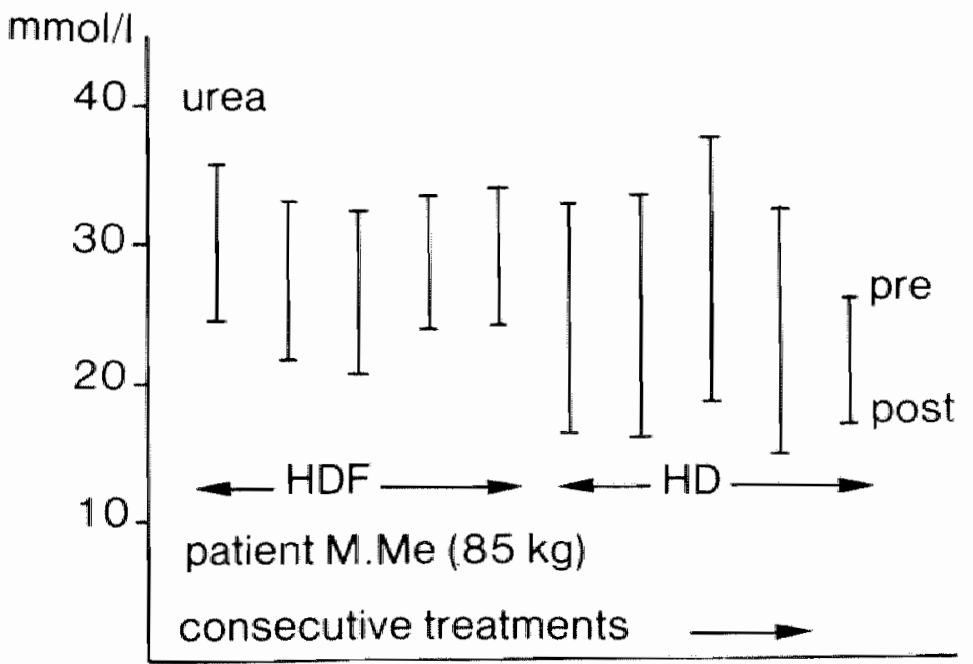

Figure 24 : Plasma urea concentrations before and after treatment in patient M. Me. in HDF and HD. 
The in vitro clearances in the foregoing chapter agree with the theoretical model that outilines the interaction between diffustve and convective mass transpart in HDF.

As already pointed out these data cannot be directly transferred to the in viwo situation because of the disturbing influences both in HD and HDF of protein coating and the presence of corpuscular elements in whole blood. To get insight into the clinical spectrum of HDF treatments clearances must be measured in vivo. Usually clearance is calculated from concentrations of solutes at the inlet and outlet of the blood or bath compartment and the momentaneous fllows at these sites (Drukker 1979, Sprenger 1981, Dieter 1977, 1981, Granger 1978, Lewis 1981). In case of a single pass system where $C_{D i}=0$ the following expression is given for clearance or dialysance:

$C 1=Q_{B i}\left(1-\frac{C_{B o}}{C_{B i}}\right)+Q_{f} \cdot \frac{C_{B o}}{C_{B i}}$

where : $C l=$ clearance, $Q=$ flow, and $C=$ concentration

$B_{1}=$ blood inlet, $B_{0}=$ blood autlet.

However these calculations become unrelliable in the presence of high ultrafiltration flows, especially if the ultrafiltration coefficient, provided by the manufacturer must be used to estimate the actual wltrafiltration flow. Moreover as this approach is a mamentaneous measurement, steady state conditions are mandatory. Measurement of $\mathrm{Q}_{\mathrm{Bi}}$ and $\mathrm{Q}_{\mathrm{BO}}$, traditionally done by the air-bubble race track method is rather inaccurate. Finally, in samples taken 
from the venous blood line concentration disequilibrium between the red cells and plasma might influence the outcome (Schindhelm $1978)$

Therefore an alternative approach was chosen that is applicable in the same way to both HD and HDF procedures, and that is anaiogous to the clinical determination of the endogenous creatinine clearance. Clearance is given by the following expression : $c 1=\frac{\text { tatal amount of solute removed }}{\text { mean arterial concentiration } x \text { treatment time }}$

This approach gives information about the mean value of the clearance during the whole treatment session. The execution denands collection of all dialysate and ultrafiltrate and repeated sampling from the arterial line. The major drawback of this method is that the decline of arterial concentration is non-linear and this must be taken into account if the mean value is calculated. Assuming distribution of small molecular solutes in a single pool, the following mass balance exists:

$c_{d} \times V_{d}=A\left(C_{0}-C_{e}\right)$, where,

$C_{d}=$ the concentration of solute in the wasted dialysate and ultrafiltrate.

$V_{d}=$ the wollume of the wasted dialysate and ultrafiltrate.

$c_{0}=$ the arterial concentration at the start of the procedure.

$C_{e}=$ the arterial cancentration at the end of the procedure.

$A=$ the volume of distribution in the body.

In practise the unstable conditions at the start and the end of the procedure were avoided and the first sample $\left(C_{y}\right)$ was taken 15 minutes after the start and the second sample $\left(C_{t}\right) 15$ minutes before the end of the procedure as is shown in figure 25 . 
Between the various concentrations the following relations exist:

$c_{a}=c_{i} \cdot e^{K \cdot \Delta t / A}$
$c_{e}=c_{t} \cdot e^{-K \cdot \Delta t / A}$
$c_{t}=c_{i} \cdot e^{-K \cdot T / A}$

where $K=$ clearance, $T=$ time interval between $C_{j}$ and $C_{t}$.

From these equations $A$ can be solved:

$A=\frac{K \cdot T}{\ln ^{C} C_{i / C_{t}}}$ and substituted in (VII) giving:

$c_{d} \times v_{d}=\frac{K . T}{\ln _{i} C_{i} c_{t}}\left(C_{i} \cdot e^{\frac{K}{A} \Delta t}-c_{t} \cdot e^{-\frac{K}{A} \Delta t}\right)$

This can be rearranged to yield:

$K=\frac{C_{d} \times V_{d} \times \ln C_{i / C_{t}}}{T\left(C_{i} \cdot e^{\frac{K}{A} \Delta t}-C_{t} \cdot e^{-\frac{K}{A} \Delta t}\right)}$

as $\frac{k}{A}=\frac{1 n^{C} i / C_{t}}{T}$ clearance is given by:

$k=\frac{C_{d} \times V_{d} \times 1 n_{i / C_{t}}}{T\left[C_{i}\left(\frac{C_{i}}{C_{t}}\right)^{\Delta t}-c_{t}\left(\frac{C_{t}}{C_{i}}\right)^{\frac{\Delta t}{T}}\right]}$

With this equation clearance can be calculated from any two samples taken at arbitrary times during the treatment session.

With this method urea and creatinine clearances were studied in two uremic patients with different body weight.

For these small molecular solutes a single pool distribution within the body was assumed.

Patient $A$ was a 75 years old female patient with a body weight of $44 \mathrm{~kg}$ and a body surface area of $1.4 \mathrm{~m}^{2}$. She had a Cimino-Brescia 


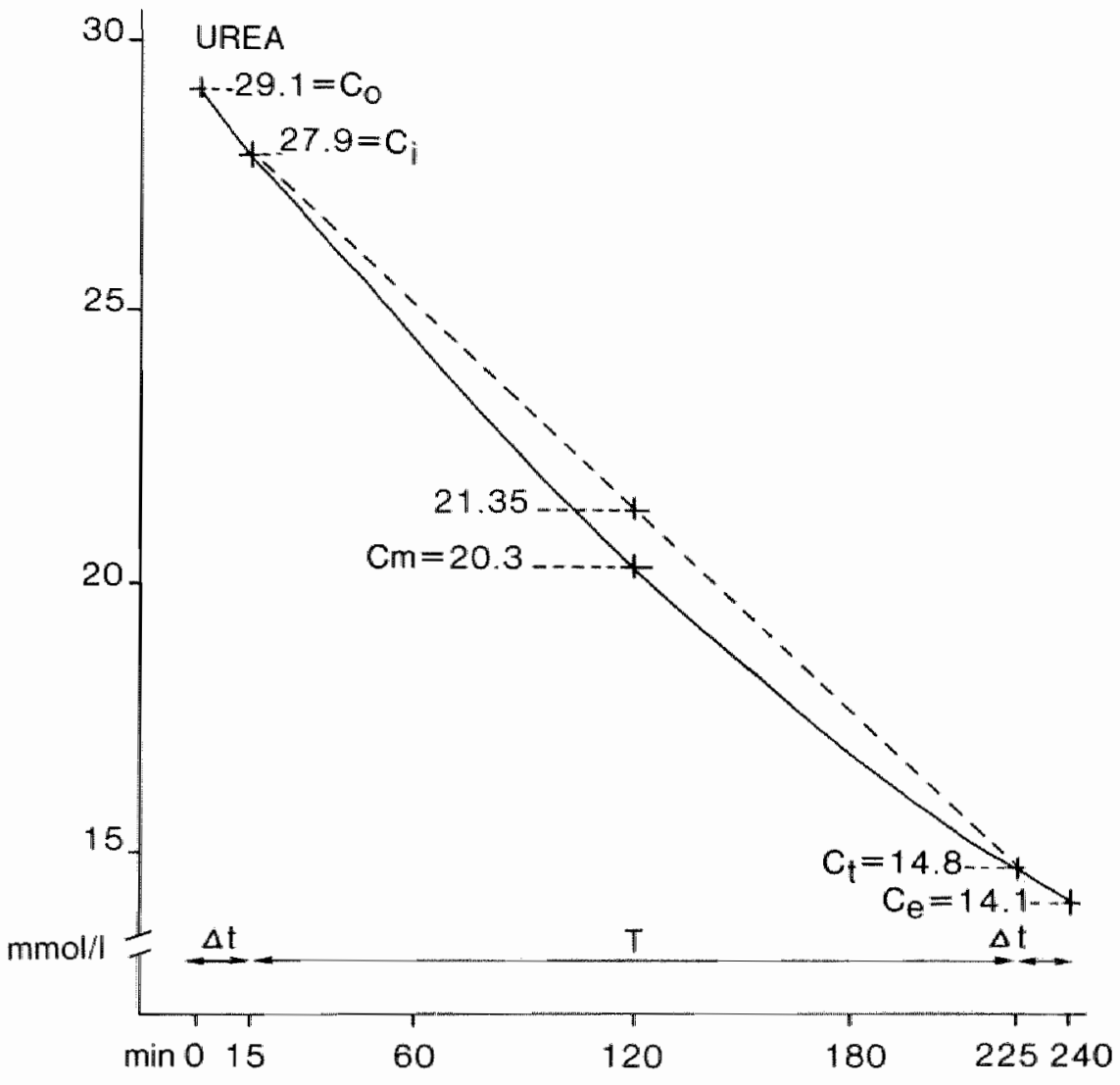

Figure 25 : The non-linear decrease of arterial plasma concentration during HD and HDF treatments.

Clearance calculated from $C_{i}$ and $C_{t}$ * 
fistula in the forearn that showed some recirculation and caused cifrculatory disturbances in the hand for which she underwent an operative correction at the beginning of the 2 months study period.

Her hemoglobin level was kept abowe 5 mol/l by means of packed cells donations to prevent manifest heart failure symptoms.

Patient $B$ was 60 years old male patient with a body weight of 79 $\mathrm{kg}$ and a body surface area of $1.96 \mathrm{~m}^{2}$. His hemoglobin level averaged 4.2 mol/1 and he had a well functioning Cimino-Brescia fistula in the forearm.

Both patients were subjected to the same treatment strategies, in which various combinations were chosen for $a_{b}(200$ and 300 $\mathrm{ml} / \mathrm{min}.), Q_{d}(100,200$, and $500 \mathrm{ml} / \mathrm{min}$.$) , and Q_{f}(5$ and $55 \mathrm{ml} /-$ min.). In addition in patient A these combinations were performed with a low bloodflow of $140 \mathrm{ml} / \mathrm{min}$. For each combination one single measurement was undertaken. All treatments lasted for 4 hours. Only RP610 dialysers were used. In all treatments the dialysate container was replaced by the is sovolumetric ultrafiltration pump to enable regimens with a high dialysate flow for 4 hours. Tables $x$ and $x$ sumarize the measured urea and creatinine clearances. For each treatment the following features are given: the average clearance in ml/min., the average clearance per square meter body surface, the total amount of solute gathered in the wasted dialysate and ultrafiltrate in moles resp. umoles, the initital (i.e. 15 minutes after the start) and terminal (1.e. 15 minutes before the end) arterial concentrations in mol/1 resp. umol $/ 1$.

As expected clearance was dependent on bloodflow and to a 
PATIENT A $\left(1.4 \mathrm{~m}^{2}\right)$

\begin{tabular}{|c|c|c|c|c|c|c|c|}
\hline & & & $\mathrm{Cl}$ & $\mathrm{c} 1 / \mathrm{m}^{2}$ & $\mathrm{C}_{\mathrm{d}} \times \mathrm{VV}_{\mathrm{d}}$ & $\mathrm{C}_{\mathrm{a} i}$ & $c_{a t}$ \\
\hline \multirow[t]{3}{*}{$\mathrm{HDF}$} & $q_{b}=140$ & $\begin{array}{l}Q_{d}=100 \\
Q_{d}=200 \\
Q_{d}=500\end{array}$ & $\begin{array}{l}73 \\
70 \\
87\end{array}$ & $\begin{array}{l}52 \\
50 \\
62\end{array}$ & $\begin{array}{l}336 \\
233 \\
330\end{array}$ & $\begin{array}{l}23.9 \\
18.2 \\
23.0\end{array}$ & $\begin{array}{l}14.9 \\
10.4 \\
10.2\end{array}$ \\
\hline & $Q_{b}=200$ & $\begin{array}{l}Q_{d}=100 \\
Q_{d}=200 \\
Q_{d}=500\end{array}$ & $\begin{array}{r}87 \\
101 \\
107\end{array}$ & $\begin{array}{l}62 \\
72 \\
76\end{array}$ & $\begin{array}{l}312 \\
375 \\
3611\end{array}$ & $\begin{array}{l}19.6 \\
21.7 \\
20.7\end{array}$ & $\begin{array}{r}10.9 \\
10.4 \\
8.8\end{array}$ \\
\hline & $\mathrm{O}_{\mathrm{b}}=300$ & $\begin{array}{l}Q_{d}=100 \\
Q_{d}=200 \\
Q_{d}=500\end{array}$ & $\begin{array}{l}106 \\
113 \\
147\end{array}$ & $\begin{array}{r}76 \\
81 \\
105\end{array}$ & $\begin{array}{l}541 \\
564 \\
683\end{array}$ & $\begin{array}{l}31.0 \\
27.9 \\
28.8\end{array}$ & $\begin{array}{l}13.5 \\
14.8 \\
11.9\end{array}$ \\
\hline HD & $\begin{array}{l}Q_{b}=140 \\
Q_{b}=200 \\
Q_{b}^{b}=300\end{array}$ & $\begin{array}{l}\mathrm{Q}_{\mathrm{d}}=500 \\
\mathrm{Q}_{\mathrm{d}}=500 \\
\mathrm{Q}_{\mathrm{d}}=500\end{array}$ & $\begin{array}{l}61 \\
101 \\
116\end{array}$ & $\begin{array}{l}44 \\
72 \\
83\end{array}$ & $\begin{array}{l}156 \\
436 \\
585\end{array}$ & $\begin{array}{l}14.5 \\
29.0 \\
33.5\end{array}$ & $\begin{array}{r}7.5 \\
10.3 \\
12.0\end{array}$ \\
\hline
\end{tabular}

PATIENT B $\left(1.96 \mathrm{~m}^{2}\right)$

\begin{tabular}{|c|c|c|c|c|c|c|c|}
\hline & & & $\mathrm{Cl}$ & $\mathrm{c} 1 / \mathrm{m}^{2}$ & $c_{d} x v_{d}$ & $\mathrm{C}_{\mathrm{a}}$ & $\mathrm{c}_{\mathrm{at}}$ \\
\hline \multirow[t]{2}{*}{$\mathrm{HDF}$} & $\mathrm{Q}_{\mathrm{b}}=200$ & $\begin{array}{l}Q_{d}=100 \\
Q_{d}=200 \\
Q_{d}=500\end{array}$ & $\begin{array}{r}95 \\
112 \\
120\end{array}$ & $\begin{array}{l}48 \\
57 \\
61\end{array}$ & $\begin{array}{l}405 \\
443 \\
478\end{array}$ & $\begin{array}{l}21.8 \\
21.0 \\
22.0\end{array}$ & $\begin{array}{l}14.3 \\
12.6 \\
12.0\end{array}$ \\
\hline & $Q_{b}=300$ & $\begin{array}{l}Q_{d}=100 \\
Q_{d}=200 \\
Q_{d}=500\end{array}$ & $\begin{array}{l}126 \\
136 \\
138\end{array}$ & $\begin{array}{l}64 \\
69 \\
70\end{array}$ & $\begin{array}{l}606 \\
564 \\
473\end{array}$ & $\begin{array}{l}26.2 \\
23.0 \\
19.5\end{array}$ & $\begin{array}{l}15.0 \\
12.5 \\
10.0\end{array}$ \\
\hline HD & $Q_{b}=200$ & $Q_{d}=500$ & 1117 & 60 & 491 & 24.4 & 11.8 \\
\hline
\end{tabular}

C1 =average in vivo clearance in $\mathrm{ml} / \mathrm{min}$.

$\mathrm{Cl} / \mathrm{m}^{2}$ =clearance per square meter body surface.

$\mathrm{C}_{\mathrm{d}} \mathrm{XV}_{\mathrm{d}}=$ total amount of solute removed

$C_{a i}=$ initial arterial concentration

$C_{\text {at }} \quad$ terminal arterial concentration

Table $x$ Urea clearances in various 4 hour HDF and HD treatment strategies in two uremic patients. 
PATIENT A $\left(1.4 \mathrm{~m}^{2}\right)$

\begin{tabular}{|c|c|c|c|c|c|c|c|}
\hline & & & $\mathrm{Cl}$ & $\mathrm{cl} / \mathrm{m}^{2}$ & $\mathrm{C}_{\mathrm{d}} \times \mathrm{V}_{\mathrm{d}}$ & $\mathrm{C}_{\mathrm{a} i}$ & $\mathrm{C}_{\text {at }}$ \\
\hline \multirow[t]{3}{*}{$\mathrm{HDF}$} & $a_{b}=140$ & $\begin{array}{l}a_{d}=100 \\
a_{d}=200 \\
\alpha_{d}^{d}=500\end{array}$ & $\begin{array}{l}69 \\
69 \\
73\end{array}$ & $\begin{array}{l}49 \\
49 \\
52\end{array}$ & $\begin{array}{l}9638 \\
7462 \\
9945\end{array}$ & $\begin{array}{l}675 \\
575 \\
745\end{array}$ & $\begin{array}{l}499 \\
347 \\
415\end{array}$ \\
\hline & $q_{b}=200$ & $\begin{array}{l}Q_{d}=100 \\
Q_{d}=200 \\
q_{d}=500\end{array}$ & $\begin{array}{l}69 \\
82 \\
80\end{array}$ & $\begin{array}{l}49 \\
59 \\
57\end{array}$ & $\begin{array}{l}10340 \\
11124 \\
12427\end{array}$ & $\begin{array}{l}780 \\
760 \\
865\end{array}$ & $\begin{array}{l}505 \\
405 \\
460\end{array}$ \\
\hline & $a_{b}=300$ & $\begin{array}{l}a_{d}=100 \\
a_{d}=200 \\
a_{d}=500\end{array}$ & $\begin{array}{l}93 \\
85 \\
97\end{array}$ & $\begin{array}{l}66 \\
61 \\
69\end{array}$ & $\begin{array}{l}12030 \\
12118 \\
12311\end{array}$ & $\begin{array}{l}765 \\
825 \\
785\end{array}$ & $\begin{array}{l}360 \\
411 \\
329\end{array}$ \\
\hline $\mathrm{HOD}$ & $\begin{array}{l}a_{b}=140 \\
Q_{b}=200 \\
a_{b}=300\end{array}$ & $\begin{array}{l}\mathrm{q}=500 \\
\mathrm{~d}=500 \\
\mathrm{~d}_{\mathrm{d}}=500\end{array}$ & $\begin{array}{l}54 \\
72 \\
86\end{array}$ & $\begin{array}{l}39 \\
51 \\
61\end{array}$ & $\begin{array}{r}5460 \\
10551 \\
13728\end{array}$ & $\begin{array}{l}560 \\
920 \\
920\end{array}$ & $\begin{array}{l}314 \\
382 \\
460\end{array}$ \\
\hline
\end{tabular}

PATIENT B $\left(1.96 \mathrm{~m}^{2}\right)$

\begin{tabular}{|c|c|c|c|c|c|c|c|}
\hline & & & C1 & $01 / \mathrm{m}^{2}$ & $\mathrm{C}_{\mathrm{d}} \mathrm{XV}_{\mathrm{d}}$ & $\mathrm{C}_{\mathrm{ai}}$ & Cat \\
\hline \multirow[t]{2}{*}{ MDF } & $a_{b}=200$ & $\begin{array}{l}Q_{d}=100 \\
Q_{d}=200 \\
\alpha_{d}=500\end{array}$ & $\begin{array}{l}79 \\
81 \\
95\end{array}$ & $\begin{array}{l}40 \\
41 \\
48\end{array}$ & $\begin{array}{l}19116 \\
20400 \\
23373\end{array}$ & $\begin{array}{l}1255 \\
1240 \\
1305\end{array}$ & $\begin{array}{l}795 \\
870 \\
775\end{array}$ \\
\hline & $\mathrm{Q}_{\mathrm{b}}=300$ & $\begin{array}{l}Q_{d}=100 \\
Q_{d}=200 \\
Q_{d}=500\end{array}$ & $\begin{array}{r}95 \\
101 \\
109\end{array}$ & $\begin{array}{l}48 \\
52 \\
56\end{array}$ & $\begin{array}{l}24957 \\
15389 \\
22126\end{array}$ & $\begin{array}{l}1405 \\
1330 \\
1100\end{array}$ & $\begin{array}{l}840 \\
815 \\
630\end{array}$ \\
\hline HD & $\mathrm{Q}_{\mathrm{b}}=200$ & $\mathrm{C}_{\mathrm{d}}=500$ & 87 & 44 & 22670 & 1480 & 755 \\
\hline
\end{tabular}

C1 average in wivo clearance in $\mathrm{ml} / \mathrm{min}$.

$\mathrm{Cl} / \mathrm{m}^{2}=c$ learance per square meter body surface.

$\mathrm{C}_{\mathrm{d}} \mathrm{XV}$ d total amount of solute removed

$\mathrm{C}_{\mathrm{a}} \quad$ =initial arterial concentration

$\mathrm{c}_{\text {at }} \quad$ terminal arterial concentration

Table $\times 1$ Creatinine clearances in various 4 hour HDF and HD treatment strategies in two uremic patients. 
lesser extent to diallysate flow, increasing with higher flows.

In patient $A$ urea and creatinine clearances were on the avarage 10\% lower than in patient $B$, which is probably due to recirculation within the shunt and differences in hematocrit. However, because of the large difference in body size between the two patients, dialyser performance as expressed by clearance per square meter body surface was more efficient in patient $A$. This might also explain the relatively larger volumes of distribution within the body in patient A compared to patient B 162 vs $55 \%$ for urea and 62 vs $49 \%$ for creatinine). The total amount of creatinine recovered from patient A was $56 \%$ of that of patient B, corresponding to the difference in body weight and constitution. 
In clinical practise HDF proved to be superior to conventional HD with regard to the treatment tolerance, the stability of the blood pressure during the treatment, the possibility of rapid fluid withdrawal in a relatively short period in the absence of troublesome symptoms. This experience is shared by others performing either HF or HDF (Kishimoto 1980, Kunitomo 1978, Leber 1980). The results of the cross-over study support the conclusion that these advantages must be inherent to this treatment modality itself and not only be due to a better fluid balance control, because during HD fluid balance was controlled as accurately as during HDF. High osmotic pressure in plasma does not seem to be an absolute prerequisite for the vascular stability, as the relatively low sodium concentrations in the substitution fluid $(138 \mathrm{mmol} / 1)$ and dialysate (134 mmol/1) allow the plasma osmotic pressure to drop 15 mosmol/l in the course of a HDF treatment. Nevertheless, due to the higher sodium concentration in the substitution fluid, sodium balance in HDF has been less negative than in HD. Accurate calculation of sodium balance is hardly feasible in an open circuit as this balance is governed by small concentration differences in relatively large volumes. Moreover the Gibbs-Donnan equillibrium should be taken into account, although its value in convective transport situations is questionable (Shaldon 1981). The slightly less negative sodium balance in HDF might have contributed somewhat to the better vascular stability that was seen in HDF. As blood pressure behaviour is stable already at the onset of HDF treatments a pathogenetic role for retained middle molecular 
toxins seems to be unlikely. Autonomous neuropathy could in our population of dialysis patients not be associated with vascular instability. 20 patients were examined by 5 non-invasive tests and about half of this population showed disturbamces. Instability of bllood pressure behaviour however is observed frequently in those without signs of autonomous neuropathy. In the 3 patients from the cross-over study with peripheral neuropathy blood pressure was more stable than in the others. Finally acetate influx does not seem to play a decisive role, as both in HD and HDF the patients were exposed to comparable amounts of acetate. The pathophysiolagic regulation of blood pressure during artificial kidney treatment is not completely understood. This study does ont provide a solution of this complex problem. An interesting question yet to be solved is to define the lower limit of ultrafiltration that is necessary to garantee stable blood pressure behaviour during HOF.

Diallyser performance is assessed by clearance studies. These were undertaken for urea and creatinine, for which a single pool of distribution in the body was assumed; to compare various HD and HOF treatment strategies (Widerde 1974. Popovich 1976). In the conventional approach in which clearance is calculated from arterial and venous sampling and determination of the blood flow at the inlet and outlet of the dialyser, momentaneous fluctuations will cause considerable variability in the outcome. These fluctuations are avoided by applying an alternative method in which the average clearance is calculated from the total anount of waste products collected during the whole treatment session.

The relative contribution of divergent treatment prescriptions was thus assessed in two uremic patients. At low dialysate flows 
of $100 \mathrm{ml} / \mathrm{m}$. predicted by the mathematical concept and in vitro data, a finding that was also reported by Jaffrin (1981) using the same kind of dialyser. The cause of this discrepancy is unknown. One could speculate that at these low dialysate flows the relative predominance of ultrafiltration might induce geometric inhomogeneities within the dialyser preventing an even distribution of flow in the dialysate compartment. At dialysate flows above $200 \mathrm{ml} / \mathrm{min}$. this discrepancy disappears. At a filtration flow of $50 \mathrm{ml} / \mathrm{min}$., the weekly clearance of middle molecules will be over 30 liters. The therapeutic value of this lower limit is still speculative. A sensitive parameter relating specific uremic manifestations to the retention of taxic middle molecules is not awailable. As long as there is no abjective indicator as to what constitutes adequate treatment, an absolute treatment prescription cannat be defined and the choice of treatment prescription for any individual patient is based on empirical consideratons. If signs of underdialysis are suspected in any particular patient the most effective measure is to raise the bloodflow. 
If treatment strategies are to be evaluated, awareness of the limitations of our current approach is indispensible.

Firstly, it is not entirely possible to give exact predictions of in vivo clearances on the basis of mathematical models. This is especially true for solutes that are partialiny rejected by the membrane like middle molecules. For these solutes total membrane resistance as a function of a diffusive and a convective transport factor is expressed by Spiegler's equation (Spiegler 1966). These factors can be calculated using iterative procedures, but it also involves the application of thin film theories, as the exact concentrations in blood at the membrane surface can not be directly measured. For daily use this kind of approach seems to be rather cumbersome.

Secondly for middle molecules a single pool model overestimates the removal from the body because of the hold-up in the intracellular compartment, especially when these molecules are generated intracellularly, as was pointed out by frost (Frost 1977). As the effectiveness of dialyser treatment for middle molecules is limited by physiological constraints, Popovich considered dialyser clearances over $100 \mathrm{ml} / \mathrm{min}$. for MM not usefull (Popovich 1976). Al so the lower limit of $30 \mathrm{~L} / \mathrm{wk}$ according to the dialysis index of Babb, that is based upon a single pool assumption, can be questionned. The occurrence of neuropathy in the presence of low middle molecule clearances has not been unanimously confirmed (Cambi 1973).

These considerations support the view of the advocates of urea 
as a target compound in a single pool model to evaluate adequacy of dilasis treatment (Gotch 1980, De Fremont 1982). However, as urea is directly related to protein catabolic products, this can only be done in the presence of adequate protein nutrition. Urea generation rate is calculated from the residual renal function and intradialytic blood levells. From balance studies in uremic patients, sargent found the following relationship between urea generation rate $\left(G_{U}\right)$ and the protein catabolic rate (PCR):

$G_{u}(g r / 24 h)=0.154$ PCR $(g r / 24 h)=1.7$ (Sargent 1978).

According to Gotch adequate nutritional managenent is reflected by PCR's between 0.8 and $1.4 \mathrm{gr} / \mathrm{kg} / 24 \mathrm{~h}$. For some unknown reason limpaired oral intake or toxic inhibition of intestinal protein absorption?) PCR decreases with declining renal function (correlation coefficient 0.87 ) and in untreated uremic patients with a residual clearance of less than $4.5 \mathrm{ml} / \mathrm{min}$. he found PCR's below $0.8 \mathrm{gr} / \mathrm{kg} / 24 \mathrm{~h}$. He studied this phenomenon in 12 uremic patients with a residual clearance of less than $0.5 \mathrm{ml} / \mathrm{min}$. who switched from conventional hemodialysis: $3 \times 6 \mathrm{~h} / \mathrm{wk}$ (urea clearance 140 $\mathrm{ml} / \mathrm{m} / \mathrm{n}$.), to hemofiltration: $3 \times 4 \mathrm{hr} / \mathrm{wk}$ (urea clearance $85 \mathrm{ml} /-$ min.). Kinetic analysis with the single pool urea model predicted predialysis Bun levels to rise from 60 to $125 \mathrm{mg} / \mathrm{dl}$. However the predialysis BuN level only rose to $90 \mathrm{mg} / \mathrm{d}$ l because of a concomittant decrease of PCR from 1.04 to $0.75 \mathrm{gr} / \mathrm{kg} / 24 \mathrm{~h}$ (Gotch 1980) (data from Baldamus). Observing these restrictions urea kinetics nevertheless appear to be appropriate for monitoring adequacy of dialysis treatment in conjunction with due nutritional counseling. During the period of observation no untowand effects related to the relatively low small molecule clearance were noted. However in 
the light of the present state of knowledge - the middle molecule hypothesis might still turn out to be a dying hypothesis - low clearances of small molecular solutes should not be recommended on the long term.

For an average built patient without residual renal function HDF treatments $(12 \mathrm{~h} / \mathrm{wk})$ with high flux membranes yield sufficient clearance of all molecular solutes at a filtration flow of 50 ml/min., a dialysate flow of $150 \mathrm{ml} / \mathrm{min}$, and a bloodflow of 250 $\mathrm{ml} / \mathrm{min}$.

The overall costs of this kind of treatment with the volume restricted apparatus that has been presented will hardly exceed those of conventional dialysis treatments. Additional costs are made by the use of high flux dialysers, the disposable PVC bags and tubing, and 10 liters of substitution fluid. Savings are made by the reduced amount of dialysate, the low costs of purchase and maintenance serwice of this equipment and, it may also result in a reduction of morbidity and consequent hospitalisation in the long term. The rising hemoglobin levels, seen during the pilot study, support this hopeful expectancy. To what extent patients will benefit in the long term from increased cardiovascular stability must be elucidated by further studies. 
CHAPTER VII. SUMMARY.

This thesis is concerned with the technical accomplishment and clinical application of hemodiafiltration treatments. In this kind of treatment hemodialysis and hemofiltration take place simultaneously to cause mass transport by combined diffusion and conwectron.

The second chapter describes how clinical observations gave rise to the so called middle molecule hypathesis, which stimulated the research in the field of membrane technology and also it promoted the elaboration of a new method of blood purification that was called hemofiltration, being analogous to the function of the natural glomerulus. In the presence of highty permeable membranes large amounts of ultrafiltrate are produced under the influence of a hydrostatic pressure gradient. This ultrafiltrate is replaced by an equal amount of substitution fluid, which can be infused before the dialyser at the arterial line: predilution (Henderson), or behind the dialyser at the venous line: postdilution (Quellthorst). The most remarkable observation of these pioneers was the vascular stability in relation to fluid withdrawal during these procedures. The pathophysiological background of this phenomenon has not yet been clarified. The predominant advantage of high middle molecule clearances was partially offset by the relatively low clearance of small molecules, when compared to conventional hemodialysis.

This engaged us in considering combined hemodialysis and hemofiltration, which is presently called: hemodiafiltration. Similar developments took place in several japanese centers and in 
Europe especially at the University clinic of biessen (FRG). clinical application of this kind of treatment on a large scale was hindered by the complicated technical provisions that were necessary to ensure an adequate control of fluid balance. We have solved these problems stepwise and we have succeeded in el ininating the inclusion of vulnerable electronic equipment.

The first step was the development of an isovolumetric pump that garantees exact control of the ultrafiltration rate during conventional single pass hemodialysis procedures. This pump is described in more detail in chapter IIC.

The second step was the development of a device that garantees exact balancing of the rate of uitrafiltration and substitution during hemofiltration procedures. This was established by joining two compartments in one airtight closed container, in which a compressible PVC bag separates the fresh substitution fluid from the wasted ultrafiltrate.

Before the application of this principle a mathematical model was worked out in chapter III to quantify the interaction and the relative contribution to overall mass transport of simultaneously applied diffusion and convection in hemodiafiltration. On account of these calculations the demands for the construction and capacity of a hemodiafiltration apparatus could be defined.

Chapter IIIb reports the results of a pilot study that was undertaken to explore the tolerance and long term effects of this kind of treatment, as, at that time, no information was avaliable from the literature about this subject. The tolerance proved to be excellent and there was no change of relevant parameters in the course of $1 \frac{1}{2}$ years except for a rise in hemoglobin level. 
In chapter IVa a detalled description is given of the protatype of the hemodiafiltration apparatus that is suitable for clinical application. In this closed volume apparatus the principle of a compressible PVC bag, suspended in an airtight cllosed container is applied to the hemofiltration circuit as well as to the hemodialysis circuit.

In in witro studies, described in chapter IVb, the functional integrity of this apparatus was tested and 3 different kinds of diallysers, equipped with high flux membranes, were evaluated. Although there was considerable difference in structure and membrane composition, the performance of these 3 types of dialysers in hemodiafiltration simulations was almost alike. However there was some discrepancy between the capacity measured in our own flow bench set up and the specifications given by the manufacturers.

The validity of the mathematical model was confirmed by fitting the measured clearance values to the theoretical curves predicted from equation III as is shown in figure 19. The most important conclusion was that hemodiafiltration permitted a $75 \%$ reduction of dialysate flow compared to conventional hemodialysis to yield sufficient clearance of all molecular sizes. As expected middle molecule clearance was considerably higher than in conventional hemodialys is.

Chapter Va reports the results of a clinical cross-over study (hemodialysis: Ho versus hemodiafiltration: HDF) in 6 patients during 6 weeks. During this study the following treatment regimens were chosen: $H D: 3 \times 4 \mathrm{~h} / \mathrm{wk}, Q_{d}=500 \mathrm{ml} / \mathrm{min} ., a_{b}=200 \mathrm{ml} / \mathrm{min}$. and HDF: $3 \times 3 \frac{\mathrm{h}}{\mathrm{h}} / \mathrm{wk}, \mathrm{Q}_{\mathrm{d}}=100 \mathrm{ml} / \mathrm{min} ., \mathrm{Q}_{\mathrm{b}}=200 \mathrm{ml} / \mathrm{min}$. and $\mathrm{Q}_{f}=$ $50 \mathrm{ml} / \mathrm{min}$. In HDF treatment time was reduced by 30 minutes. Never- 
theless blood pressure behaviour during net fluid withdrawal was considerably more stable in HDF than in HD. This was parallelled by an increased feeling of well-being in HDF. The concentrations of electralytes and small molecular waste products before and after treatment were of comparable magnitude in $H D$ and HDF except for urea, of which the extraction was somewhat lower in HDF.

Chapter wb presents the variation in clearance or dialysance over the full range of possible HOF strategies with divergent flow conditions in two additional patients. As the accuracy of the traditional method of in vivo clearance determination with simultaneous sampling and flow measurements in the arterial and venous line is doubtfull, an alternative approach was chosen that is analogous to the clinical assessment of endogenous creatinine clearance and that can be applied in the same way to HDF and HD regimens.

Finally, in the absence of an objective indicator as to what constitutes adequate treatment, the prescription policy, that is generally based upon empirical considerations, is discussed. The role of middle molecules in the production of the uremic syndrome is still a controversial topic and therefore they do not seen to be suitable to guide our therapeutic planning. On the other hand, if urea is relied upon as a uremic marker its relation to protein catabolism should be taken into consideration. The better agreement of the HDF clearing profile to the function of the natural kidney and the excellent tolerance of this kind of treatment promate HDF to the optimal artificial kidney treatment, presently available. 
In dit proefschrift worden de technische verwezenlijking en de klinilsche toepassing van hemodiaflltratie behandelingen beschreven. Bij deze combinatie van hemodialyse en hemofiltratie vindt massa transport plaats door simultane diffusie en convectie.

In hoofdstuk II wordt beschreven hoe klinische warnemingen aanleiding vormden tot de formulering van de z.g. niddle molecule hypothese, die enerzijds het wetenschappelijk onderzoek van kuinstniermembranen bevorderde en anderzijjs de ontwikkeling stimuleerde van een geheel nieuwe bloedzuiveringstechniek, die overeenkomst toont met de werking van de menselijke glomerulus: de hemofiltratie. Gebruik makend van hoog doorlaatbare membranen wordt in deze procedure een grote hoeveelheid ultrafiltraat gewormd onder invloed van een hydrostatische drukgradient. Dit ultrafiltraat wordt vervangen door een gelijke hoeveelheid infuus oplossing. De substitutie van deze oplossing kan platsvinden in de arteriële aanvoerlijn woōor de kunstnier: predilutie (Henderson), of in de veneuse afvoerlijin achter de kunstnier: postdilutie (Quellhorst). De belangrljkste klinische warneming van deze pioniers was de stablititelt van de bloeddruk tijdens het vocht onttrekken in de loop van zulke behandelingen. Het exacte pathofysiologische mechanisme van deze bloeddruk regulatie is overigens nog niet opgehelderd. Hoewel de klaring van midden moleculaire toximen hoog was, viel de klaring van klein moleculaire toxinen in vergelijking tot conventionele hemodialyse laag uit.

Dit was woor ons de aanleiding te trachten hemodialyse en hemofiltratie in ēen zitting simultaan te doen plaatsvinden: dit 
proces wordt aangeduid met de term "hemodiafiltratie". In enkele Japanse centra en met name in de Universiteitskliniek van Giessen (West-Duitsland) werd eveneens aan een dergelijke oplossing gewerkt. Een uitgebreide klinische toepassing werd echter belenmerd door de ingewikkelde electronische apparatuur die nodig is on een nauwkeurige controle uit te oiefenen op de vochtbalans. Deze problemen werden door ons stapsgewijs opgelost, zodanig dat het gebruik van ingewikkelde apparatuur overbodig werd.

De eerste stap was de ontwikkeling van een isovolumetrische pomp, warmee de snelheid van ultrafiltratie tijdens conventionele hemodialyse procedures in een open single pass circuitt nauwkeurig geregeld kan worden. Deze pomp wordt gedetallleerd beschreven in hoofdstuk IIc.

De tweede stap was de ontwikkeling van een systeem dat verzekert dat de snelheid van ultrafiltratie precies gelijk is aan de snelheid van infusie van substitutie vloeistof. De oplossing hiervoor werd gevonden in de vorm van een gesloten tank, warin zich een samendrukbare PVC zak bevindt. In deze zak bevindt zich verse substitutie woeistof en in de angevende ruimte bevindt zich het gevarmde ultrafiltrat.

Alvorens dit principe in praktijk te brengen werd in hoofdstuk III een mathematisch model uitgewerkt wamee inzicht werd verkregen in de interaktie tussen diffusie en convectie en hun relatieve bijdrage in het massa transport tijdens simultane hemodialyse en hemofiltratie. Op grond hiervan werden eisen geformuleerd t.a.v. de constructie en de capaciteit van hemodiafiltratie apparatuur.

In hoofdstuk IIIb worden de resultaten beschreven van een $1 \frac{1}{2}$ 
jadr durende pllot studie, warin de talerantie van hemodiafiltratie behandelingen en de effekten op lange termijn werden onderzocht. In de 1 it teratur waren destijds hierower nog geen gegevens bekend. De tolerantie bleek uitstekend en op de lange duur werden geen veranderingen wargenomen in de relevante parameters behoudens een stijging van het hemoglobine gehalte.

In hoofdstuk IV wordt het prototypie wan een hemodiafiltratie machine beschreven die geschikt is voor klinische toepassing. In deze machine is het principe van een gesloten tank met darin een samendrukbare PVC zak zowel woor het hemofiltratie circuit als voor het hemodialyse circult toegepast.

Tijdens in vitro proeven, welke zijn beschreven in hoofdstuk IVb, werd de functionele integriteit van deze machine getest en werden 3 verschillende soorten kunstmieren, uitgerust met $\mathrm{z} . \mathrm{g}$. high-filux membranen onderzocht. Hoewel er belangrijke verschillen bestaan in de constructie en membraan samenstelling, bleken deze 3 types kunstnieren gelijkwaardig wat betreft hun geschiktheid voor hemodiafiltratie toepassingen. Wel bestond er enige discrepantie tussen de door ons zelf gemeten capaciteit en de door de producenten opgegeven eigenschappen.

Tenslotte werd de geldigheid van het mathematisch model bevestigd doordat de gemeten klaringen overeen bleken te komen met de voorspellingen op grond van formule III. De belangrijkste conclusie van deze in vitro onderzoekingen was dat tijdens hemodiafiltratie de badwater flow met $75 \%$ gereduceerd kan worden om voldoende klaring op te leveren van klein-en middenmoleculaire toxinen. Zoals te verwachten was de klaring van middemoleculaire toxinen aanzienlijk hoger dan tijdens conventionele hemodialyse. 
In hoofdstuk Va worden de resultaten beschreven wan een 6 weken durende cross-over studie bij 6 patienten (hemodialyse : HD versus hemadiafiltratie : HDFl. Hierbij werd gekozen voor de valgende behandelingsstrategieën : $H D: 3 \times 4$ uur/week, $Q_{d}=500$ ml $/ \mathrm{min} ., Q_{b}=200 \mathrm{ml} / \mathrm{min}$, en HDF $3 \times 3 \frac{1}{2}$ uur $/$ week, $Q_{d}=100$ $\mathrm{ml} / \mathrm{min}$., $Q_{b}=200 \mathrm{ml} / \mathrm{min}$., en $Q_{f}=50 \mathrm{ml} / \mathrm{min}$. Hoewel de HDF behandelingen $\frac{1}{2}$ uur korter duurden bleek het beter mogelijk om vocht te onttrekken en het verloop wan de bloeddruk was stabieler dam tijdens HD, hetgeen gepaard ging met een toegenonen subjectief welbevinden. De concentraties van electralieten en kleinmoleculaire toxinen vōōr en na behandeling waren niet significant verschillend in HD en HDF, met uitzondering van ureum, waarvan de extractie tijdens HDF lager bleek te zijin.

Derhalve werden in hoofdstuk $V b$ in vivo klaringen gemeten tijdens zeer uiteenlopende HDF behandelingsstrategieën met verschillende flow verhoudingen in 2 patienten van verschillend lichaamsgewicht. Aangezien de nauwkeurigheid van de gebruikelijike in vivo klaringsberekening aan de hand van monstermame uit de arteriele en veneuze lijn en gelijktijdige bepaling van de flows met behulp van een luchtbel twijfelachtig is, werd gekozen voor een alternatieve methode die overeenkont met de klinisch toegepaste endogene creatinine klaringsberekening, en die op dezelfo wijze toegepast kan worden in $\mathrm{HD}$ en HDF behandelinger.

In de discussie wordt tenslotte ingegaan op het empirisch karakter van behandelingswoorschriften blj dialyse, aangezien er geen algemeen geldig criterium bestat voor een adequate therapie. De betekenis van middemoleculen in relatie tot het uremische symdroom is nog controversieel, en daarom $1 \mathrm{ijk}$ en zijj geen geschikte 
gradmeter voor onze therapeutische planning. Indien darentegen ureum gehanteerd wordt als criterium om het beleid op af te stemmen, dient men daarin de afhankelijkheid wam het eiwit katabolisme te betrekken. De goede overeenkonst van het klaringsprofiel van HDF met de functie van de normale glomerulus en de uitstekende tolerantie wan deze behandelingen maken HDF tot de beste keuze uit de mogelljke kunstnier behandelingen die ons heden ten dage ter beschikking staan. 
thetefore:

$F_{b(x)}=-E_{0} \cdot w_{b}$ and

$F_{d}(x)=f \cdot B \cdot-\left(Q_{d}+Q_{f}\right)$

with this equation the following rearrangement can be made:

$\frac{-d\left(F_{b(x)} \cdot C_{b}(x)\right.}{d x}=-F_{b(x)} \frac{d C_{b}(x)}{d x}-C_{b(x)} \frac{d F_{b}(x)}{d x}=-F_{b(x)} \frac{d C_{b}(x)}{d x}+F \cdot B \cdot C_{b(x)}$

This can be substituted in (II) to yield:

$-F_{b}(x) \frac{d c_{b}(x)}{d x}=K \cdot B \cdot\left(C_{b(x)}-C_{d(x)}\right)$

in the same way:

$\frac{d(F) d(x) \cdot C_{d}(x)}{d x}=F_{d}(x) \frac{d C_{d}(x)}{d x}+C_{d}(x) \frac{d F(x)}{d x}=F_{d}(x) \frac{d C_{d}(x)}{d x}+f \cdot B \cdot C_{d}(x)$

This can be substituted in (III) to yield:

$F_{d(x) \frac{d}{d x}}=\left(f+K^{k}\right) \cdot B_{n}\left(C_{b(x)}-C_{d(x)}\right)$

$(V)$ and (VI) can be rewritten:

$\frac{d C_{b}(x)}{d x}=-\frac{K \cdot B}{F_{b(x)}}\left(C_{b(x)}-C_{d(x)}\right)$ and

$\frac{d C d(x)}{d x}=\frac{(f+k) \cdot B}{F_{d}(x)}\left(C_{b(x)}-C_{d(x)}\right)$

After subtraction $\left(\Delta C_{(x)}=C_{b(x)}-C_{d(x)}\right):$

$\frac{\mathrm{d} \Delta \mathrm{C}(\mathrm{x})}{\mathrm{d} \mathrm{x}}=\left(\frac{-\mathrm{K} \cdot \mathrm{B}}{\mathrm{F} b(\mathrm{x})}-\frac{(\mathrm{f}+\mathrm{K}) \cdot \mathrm{B}}{\mathrm{F}(\mathrm{x})}\right) \cdot \Delta \mathrm{C}_{(\mathrm{x})}$

$-\frac{-d \Delta C(x)}{d C_{(x)}}=\frac{k_{n} B}{F_{b(x)}} d x+\frac{(f+k) \cdot B}{F d(x)} d x$

From $(I): d F_{b(x)}-f \cdot B \cdot d x$ and $d F d(x)=F \cdot B \cdot d x$

Substitution in (VII) yields:

$\frac{-d \Delta C_{(x)}}{\Delta C_{(x)}}=\frac{-k}{1} \cdot \frac{d F_{b}(x)}{F_{b}(x)}+\frac{(f+k)}{f_{\cdot} F_{d}(x)} \cdot d F_{d}(x)$

$\frac{d \Delta C_{(x)}}{\Delta C_{(x)}}=\frac{K}{F} \cdot \frac{d F_{b}(x)}{F_{b(x)}}-\frac{(f+K)}{F} \cdot \frac{d F d(x)}{F_{d}(x)}$

In the countercurrent situation $F_{\mathrm{d}(\mathrm{x})}<0$, therefore after integration ( WIIT yields:

$\ln \Delta C_{(x)}=\frac{K}{f} \cdot \ln F_{b(x)}-\frac{(K+E)}{f} \cdot \ln \left(-F_{d(x)}\right)+\ln \left(-C_{1}\right)$ 
Further elaboration gives:

$$
\begin{aligned}
& \Delta C_{(x)}=-C_{1} \frac{\left(F_{b(x)}\right)^{K / f}}{\left(-F_{d(x)}\right)^{(K+f) / f}} \\
& \Delta C_{(x)}=\frac{C_{1}}{F_{d}(x)}\left(\frac{F_{b(x)}}{-F_{d}(x)}\right)^{K / E}
\end{aligned}
$$

From (II) and (III) follows:

$$
\begin{aligned}
& \frac{d F_{b(x)} \cdot C_{b(x)}}{d x}+\frac{d F_{d(x)} \cdot C_{d(x)}}{d x}=0 \\
& F_{b(x)} \cdot C_{b(x)}+F_{d(x)} \cdot C_{d(x)}=C_{2}
\end{aligned}
$$

$$
(\mathrm{x})
$$

From ( $I X)$ and ( $X)$ the following 2 equations can be written (after multiplicating ( IX) with $\mathrm{F}_{\mathrm{b}(\mathrm{x})}$ :

$$
\begin{aligned}
& F_{b(x)} \cdot C_{b(x)}-F_{b(x)} \cdot C_{d(x)}=-C_{1}\left(-\frac{F_{b(x)}}{F_{d}(x)}\right)^{(K+f) / f} \\
& F_{b(x)} \cdot C_{b(x)}+F_{d(x)} \cdot C_{d(x)}=C_{2}
\end{aligned}
$$

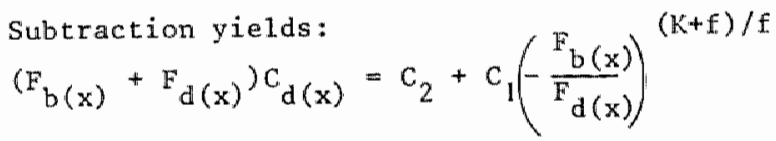

In the same way:

$$
\begin{aligned}
& F_{d(x)} \cdot C_{b(x)}-F_{d(x)} \cdot C_{d(x)}=C_{1}\left(-\frac{F_{b(x)}}{F_{d(x)}}\right)^{K / f} \\
& F_{b(x)} \cdot C_{b(x)}+F_{d(x)} \cdot C_{d(x)}=C_{2}
\end{aligned}
$$

Addition yields:
$\left(F_{b(x)}+F_{d(x)}\right) C_{b(x)}=C_{2}+C_{1}\left(-\frac{F_{b}(x)}{F_{d}(x)}\right)^{K / f}$

AS : $F_{b(x)}+F_{d(x)}=$ constant, this can be incorporated in $C_{1}$ and $C_{2}$ to yield:

$$
\begin{aligned}
& c_{d(x)}=c_{2}+c_{1}\left(-\frac{F_{b(x)}}{F_{d(x)}}\right)_{K / f}^{(K+f) / f} \\
& c_{b(x)}=c_{2}+c_{1}\left(-\frac{F_{b}(x)}{F_{d(x)}}\right)^{(x)}
\end{aligned}
$$

91 
Boundary conditions are defined by:

$$
\begin{array}{ll}
F_{b(0)}=Q_{b}, F_{b(L)}=Q_{b}-Q_{f} & , C_{b(0)}=C_{b} \\
F_{d(0)}=-Q_{d}-Q_{f}, F_{d}(L)=-Q_{d} & , C_{d(L)}=0
\end{array}
$$

Substitution in (XI) gives:

$0=c_{2}+c_{1}\left(\frac{a_{b}-Q_{f}}{-Q_{d}}\right)^{(K+\mathbb{f}) / f}$

$C_{2}=-C_{1}\left(R_{v}\right)^{(K+E) / f}$ where $\mathbb{R}_{v}$ is the ratio of fllows at the venous outlet of the dialyzer.

$\hat{c_{b}}=c_{2}+c_{1}\left(\frac{Q_{b}}{-Q_{d}-Q_{f}}\right)^{k / f}$

$c_{b}=c_{2}+c_{1}\left(R_{a}\right)^{K / t}$ where $R_{a}$ is the ratio of flows at the arterial inlet of the dialyzer.

further elaboration yields:

$C_{b}=C_{1}\left(\left(R_{a}\right)^{k / f}-\left(R_{v}\right)^{(K+f) / E}\right)$

$C_{1}=\frac{C_{b}}{R_{a}^{K / f}-R_{v}(K+f) / f}$

$C_{2}=\frac{-C_{b} \cdot R_{v}(K+f) / f}{R_{a}^{K / f}-R_{v}^{(K+f) / f}}$

The relative clearance is giwen by :

$\mathrm{Cl}_{\text {rel. }}=\frac{\mathrm{C}_{\mathrm{d}(\mathrm{O})}}{\mathrm{R}_{\mathrm{a}} \cdot \mathrm{C}_{\mathrm{b}}}$ substitution gives:

$C_{d(0)}=C_{2}+C_{1}\left(-\frac{F_{b}(0)}{F_{d}(0)}\right)^{(K+f) / f}=C_{2}+C_{1} \cdot R_{a}(K+f) / f$

$C_{d(0)}=\frac{C_{b}\left(R_{a}^{(K+f) / f}-R_{v}^{(K+F) / f}\right)}{R_{a}^{k / f}-R_{v}^{(K+f) f}}$

$\frac{C_{d(O)}}{R_{a} C_{b}}=\frac{R_{a}^{y}-R_{v}^{y}}{R_{a}^{y}-R_{a} \cdot R_{v}^{y}} \quad$ where $y=(K+f) / f$

which is the final expression for the relative clearance $\left(C 1 / Q_{b}\right)$. 
AIZAWA $Y_{*}$, HIRASAWA $Y$., SHIBATA A.

A fall of plasma osmolality created at dialyzer and its possible effects on circulating blood volume.

Clin. Nephrol. 12, 269, 1979.

BABB A.L., POPOVICH R.P., CRISTOPHER T.G., SCRIBNER B.H.

The genesis of the square meter hour hypothesis.

Trans. Am. Soc. Artif. Int. Organs 17, 81, 1971.

BABB A.L., FARRELL P.C., UVELLI D.A., SCRIBNER B.H.

Hemodialyser evaluation by examination of solute molecular weight spectra.

Trans. Am. Soc. Artif. Int. Organs 8, 98, 1972.

BABB A.L., STRAND M.J., UVELLI D.A., MILUTINOVICH J., SCRIBNER B.H.

Quantitative description of dialysis treatment: A dialysis index.

Kidney International 7, 23, 1975.

BALDAMUS C.A., SCHOEPPE W., KOCH K.M.

Comparison of hemodialysis (HO) and post-dilution hemofiltration (HF) on an unselected dialysis population.

Proc. Eur. Dial. Transpl. Assoc. 15, 228, 1978.

BALDAMUS C.A., KNOBLOCH M., SCHOEPPE W., KOCH K.M.

Hemodialysis/hemofiltration : A report of a controlled crossover study.

Int. J. Artif. Organs 3, 211, 1980.

BALDAMUS C.A., ERNST W., FREI U., KOCH F.M.

Sympathic and hemadymamic response to volume removal during 
different forms of renal replacement therapy.

Nephron 31, 324, 1982.

BERGSTRÖH נ. F FURST P.

Urenic middle molecules.

Clin. Nephral. 5, 143, 1976 a.

BERGISTRÖM J., ASABA H. FÜRST P., OULES R.

Dialysis, ultrafiltration and blood pressure.

Proc. Eur. Dial. Transpl. Assoc. 13, 293, 1976a.

BERGSTRÖM

Ultrafiltration without simultaneous dialysis for removal of excess fluid.

Proc. Eur. Diall. Transpl. Assac. 15, 260, 1978a.

BERGSTRÖM

Ultrafiltration without dialysis for removal of fluid and solutes in uremia.

C1 in. Mephrol. 9, 156, $1978 \mathrm{~b}$.

BIXLER H. J., NELSON L.M., BLUEMLE jr L.W.

The development of a diafiltration for blood purification.

Trans. Am. Soc. Artif. Int. Organs 14, 99, 1968.

BRENNER B.M., RECTOR JP F.C., (ed.)

The Kidney.

W. B. Saunders Company, Philadelphia, 1981.

BRICKER N.S., BOURGOIGNIE J., WEBER H., SCHMIDT R.W., SLATOPOLSKY

E.

Pathogenesis of the uremic state: A new perspective.

Advances in Nephrology, ed. by J.Hamburger.

Chicago, year book Medical Publishers 2, 263, 1972a. 
BRICKER N.S.

On the pathogenesis of the uremic state: An expasition of the Trade-off Hypothesis.

New Eng1. J. Med. 286, 1093, $1972 b$. BRULL L.

L'Ultrafiltration in vivo. Compt.Rend.Soc.Biol 99, 1607, 1928.

CAMBI V., DALL'AGLIO P., SVAZZI G., ARISI L., ROSSI E., MIGONE L. Clinical assessment of hemodialysis patients with reduced small middle malecule removal.

Proc. Eur. Dial. Transpl. Assoc. 9, 67, 1972.

CAMBI V., SVAZZI G., ARISI L., BUZIO C., DALL'AGLIO P., ROSSI E., MIGONE L.

Dialysis schedule and peripheral neuropathy.

Proc. Eur. Dial. Transp. Assoc. 10, 271, 1973.

CANELLA G., PICOTTI G.B., MIONI G., CRINTINELLI L., MAIORCA R.

Blood pressure behaviour during dialysis and ultrafiltration : A pathogenic hypothesis on hemodialysis induced hypotension. Int. J. Artif. Organs 1, 69, 1978.

COLTON C.K., HENDERSON L.H., FORD C.A., LYSAGHT M.J.

Kinetics of hemodiafiltration I : in vitro transport characteristics of a nollow fibre blood ultrafilter.

J. Lab. Clin. Med. 85, 355, 1975.

DIETER K., FRANZ H.E., BREITIG D., MEYER C., SCHMIOT WIEDERKEHR P. Bluddetoxification durch simultane Dialyse und Diafiltration. Bionned. Techn. 22, 277, 1977.

OIETER $K$.

Stofftransport bei Hämodialyse, Hämofíltration und Hämodiafil- 
tration.

Proceedings 1 symposion hemodiafiltration Giessen 1981 ed. G. Schutterle e.a.

DRUKKER W., PARSONS F , MAHER J.

Replacement of renal function by dialysis.

Martinus Myhoff Publ. The Hague, 2nd. edition, 1983.

DZURIK R., BOZEK P., REZNIEEK J., OBORNIKOVẼ A.

Blood level of middle molecular substances during uremia and hemodialysis.

Proc. Eur. Díal. Transpl. Assoc. 10, 263, 1973.

FLENDRIG J., CARPAY W., DEKKERS W.

The accurate control of utrafiltration.

Artif. Organs 2, 144, 1978.

DE FREMONT A.F., COEVOET B., DKHISSI A., PRUNA A., MORINIERE Ph. , CALY C., FOURNIER A.

Is blood urea mitrogen as good a guide for hemofiltration as for hemodialysis?

New Engl. d. Med. 307, 1025, 1982.

FROST T.H. , KERR D.N.

Kinetics of hemodialysis: A theoretical study on the removal of solutes in chronic renal failure compared to normal health. Kidney International $12,41,1977$.

FUNCK-BRENTANO J.L., SAUSSE A., MAN N.K., GRANGER A., RONDONNUCETE M., ZINGRAFF J., JUNGERS P.

Une nouvelle methode d"hemodialyse associant une membrane à haute permeabilitë pour les moyennes molécules et un bain de dilalyse en circuit fermé.

Proc. Eur. Dial. Transp1. Assoc. 9, 55, 1972. 
FUNCK-BRENTANO J.L., BOUDET J., SAUSSE A., CUEILLE G., MAN N.K.

In vitro sural nerve test for the evaluation of middle molecu= lar neurotoxicity in uremia.

Technical Aspects of Renal Dialysis TH Frost ed., p.256, 1978.

Pitman Medical Publ. Co Ltd London.

FüRST P., ZIMMERMAN L., BERGSTRÖM J.

Determination of endogenous middle molecules in normal and uremic body fluids.

Clin. Nephrol. 5, 178, 1976.

VAN GEELEN J.A., CARPAY W., DEKKERS W., FIERS H.A., MULDER A.W., FLENDRIG J.A.

Simultaneous hemodialysis and hemofiltration: A simple, safe and effective treatment of uremic patients.

Proceedings 2nd Meeting I.S.A.0. 119, 1979.

GINN H.E., BUGEL H.J., JAMES L., HOPKINS P.

Clinical experience with small surface area dialyzers.

Proc. Clin. Dial. Transpl. Forum 1, 53, 1971. GOTCH F.A.

A quantitative evaluation of small and middle molecule toxicity in therapy of urenia.

Dialys is and Transplantation 9, 183, 1980. GOTCH F.A., SARGENT J.A., PETERS J.H.

Studies on the molecular etfology of uremia.

Kidney International 7, 276, 1975. GOTCH F.A., SARGENT J.A.

Hemofiltration : an unnecessarily complex method to achieve hypotonic sodium removal and controlled ultrafiltration. Blood Purification 1, 9, 1983. 
GRAEFE U., MILUTINOVICH J. "FOLETTE W.C., BABB A.L., SCRIBNER B.H. Improved tolerance to rapid ultrafiltration with the use of blcarbonate in dialysate.

Proc. Eur. D1a1. Transp7. Assoc, 14, 153, 1977.

GRAEFE U., STEINHAUSEN D., LANGER K., ALTERHOFF G., KNOLL O., LOEW H.

Neuropathy and short time hemodialysis.

Proc. Eur. Dial. Transpl. Assoc. 16, 729, 1979.

GRANGER A., VANTARD G., VANTELON J., PERRONE B.

A mathematical approach of simultaneous dialysis and filtration (SDF).

Proc. Eur. Soc. Artif. Organs 15, 174, 1978.

HENOERSON L.W., BESARAB A., MICHAELS A.

Blood purification by ultrafiltration and fluid replacement (diafileration).

Trans. An. Sac. Artif. Intern. Organs 13, 216, 1967.

HENDERSON L.W., FORO CH.A., LYSAGHT M.J., GROSSMAN R.A., SILVERSTEIN M.E.

Prelininary observations on blood pressure response with maintenance diafileration.

Kidney International $7,413,1975 a$.

HENDERSON L.W., COLTON C.K., FORD C.A.

Kinetics of hemodiafiltration II : Clinical characterisation of a new blood cleamsing modality.

J. Lab. Clin. Med. 85, 372, 19756.

HENDERSON L.H., LILLY J.J., FORD C.A., STONE R.A.

Hemodiafiltration.

J. of Dialysis $1,211,1977$. 
HENDERSON L.W.

Hemofiltration for the treatment of hypertension associated with end stage renal failure.

Artif. Organs 4, $103,1980$.

HENNING H.V.

The actual significance of hemofiltration for the treatment of acute and chronic renal failure.

Int. J. Artif. Organs 3, 215, 1980.

IVANOVICH $P$.

Sequential ultrafiltration hemodialysis : 18 month"s experience.

Dialys is and Transplantation 7, 1077, 1978.

JAFFRIN M.Y., GUPTA B.B., MALBRANCQ J.M.

A one-dimensional model of simultaneous hemodialysis and ultrafiltration with highlly permeable membranes.

J. Biomechanical Engineering 1.03, 261, 1981.

JAFFRIN M. Y., BUTRUILLE Y., GRANGER A., VANTARD G.

Factors governing hemofiltration (HF) in a parallel plate exchanger with highly permeable membranes.

Trans. Am. SOC. Artif. Organs 24, 448, 1978. JAFFRIN M.Y. * VANTARD G., GRANGER A.

A concentration polarization model of hemofiltration with highly permeable membrane.

d. Am. Soc. Artif. Intern. Organs 2, 73, 1979.

JEBSEN R.H., TENCKHOFF H., HOUET J.C.

Natural history of uremic polyneuropathy and the effects of dialysis.

New Eng1. J. Med. 277, 327, 1967. 
JONES E. O., WARD M.K., HOENICH M.A., KERR D. M.S.

Separation of dialysis and ultrafiltration: does it really help?

Proc. Eur. Dial. Transpl. Assoc, 14, 160, 1977.

KISHIMOTO T., YAMAGAMI S., TANAKA H., OHYAMA T, YAMAMOTO T., YAMAKAWA M. NISHINO M., YOSHIMOTO S., MAEKAWA M. Superiority of hemofiltration to hemodialysis for treatment of chronic renal failure : comparative studies between hemofiltration and hemodialysis on dialysis disequilibrium syndrome. Artif. Organs 4, 86, 1980.

KJIELLSTRAND C.M., EVANS R.L., PETERSEN R.J., RUST L.W., SHIDEMAN J., BUSELMEIER T.J., ROSELLE L.T.

Consideration of the middle molecule hypothesis.

Proc. Dial. Transpl. Forum 2, 127, 1972.

KJELLSTRAND C.M., PETERSEN R.J., EVANS R.L.

Considerations of the middle molecule hypothesis II : Neuropathy in nephrectomized patients.

Trans. Am. Soc. Artif. Intern. Organs 19, 325, 1973.

KJELLSTRAND C.M., EVANS R.L., PETERSEN R.J., SHIDEMAN d.R., VOH HARTITZSCH B., BUSELMEIER T.J.

The "unphysiology" of dialysis : A major cause of dialysis silde effects?

Kidney International 7 (supp1.2), 30, 1975.

KLEIN E., HOLLANO F.

Evaluation of membranes for use in hemofiltration.

1 th. Annual Contractors Conference of the Artif.Kidmey Program of the N.I.A.M.D.D. contract number N 01-AM-7-2209. 1978 . 
KOHNLE W., SPRENGER K., SPOHN B., FRANZ H.E.

Hemofiltration using readily available equipment.

J. of Dialysis $3,27,1979$.

KOLFF W.J.

De Kunstmatige Nier. Thesis 1946.

KUNITOMO T., LOWRIE E.G., KUMAZAWA S., O'BRIEN M., LAZARUS J.M., GOTTLIEB M.N., MERRILL J.P.

Controlled ultrafiltration (UF) with hemodialysis (HD) : analysis of coupling between convective and diffusive mass transfer in a new HO-UF system.

Trans. Am. Soc. Artif. Int. Organs 23, 234, 1977.

KUINITOMO T., KIRKWOOD R.G., KUMAZAWA S., LAZARUS J.M. GOTTLIEB M. N., LOWRIE G.

Clinical evaluation of postdilution dilalysis with a combined ultrafiltration (UF)-hemodialysis (HO) system.

Trans. Am. Soc. Artif. Int. Organs 24, 169, 1978.

LEBER H.W., WIZEMANN V., GOUBEAUD G., RAWER P., SCHÜTTERLE G.

Simultaneous hemofiltration/hemodialysis (HD/HF) : an effective alternative to hemofiltration and conventional hemodialys is in the treatment of uremic patients.

Clin. Nephrol. 9, 115, 1978.

LEBER H.W., WIZEMANN V., TECHERT F.

Simultaneous hemofiltration/hemodialysis (HD/HF) : short- and long-term tolerance. Introduction of a system for autamatic fluid replacement.

Artif. Organs 4, 108, 1980.

LEWIS A.

Mathematical madelling of hemodiafiltration with particular 
reference to prediction of clearance.

Proceedings 1 symposion Hemodiafiltration Giessen 1981 ed. G. Schütterle e.a.

LOWRIE E.G., LAIRD N.M., PARKER T.F., SARGENT J.A.

Effect of the hemodialysis prescription on patient mobidity :

Report of the national cooperative dialysis study.

New Engl. J. Med. 305, 1176, 1981.

MAEKANA M., KISHIMOTO T., OHYAMA T., TANAKA H.

Present status of hemofiltration and hemodialysis in Japan.

Artif. Organs 4, 85, 1980.

MAIORCA R., CASTELLANI A., MIGOZZI G., PANZETTA G.0., USBERTI M.

Short time personalised dialysis : good results in spite of high levels of small and middle molecules.

Proc. Eur. Dial. Transpl. Assoc. 11, 146, 1974.

MAN N.K., GRANGER A., RONDON-NUCETE M*, ZINGRAFF J., JULGERS P., SAUSSE A., FUNCK-BRENTANO J.L.

One year follow up of short dialysis with a membrane highly permeable to middle molecules.

Proc. Eur. Dial. Transpl. Assoc 10, 236, 1973.

MAN N.K., TERLAIN B., PARIS $J$., WERNER G., SAUSSE A., FUNCKBRENTANO J.L.

An approach to middle molecules identfication in artificial kidney dialysate with reference to neuropathy prevention. Trans. Am. Soc. Artif. Organs 19, 320, 1973.

MAN N.K., CUEILLE G., ZINGRAFF J., DRUEKE T., JUNGERS P., SAUSSE A., BRILLON J.P., FUNCK-BRENTANO J.L.

Inwestigations on clinico-chenical correlations in uremic polyneuritis. 
Proc. Eur. Dial. Transpl. Assoc. 11, 214, 1974.

MAN N.K., CUEILLE G., ZINGRAFF J., BOUDET J., SAUSSE A., FUNCKBRENTANO J.L.

Uremic toxin in the middle molecular weight range.

Artif. Organs 4, 116, 1980.

MIGONE L., DALL'AGLIO P., BUZIO C.

Middle molecules in uremic serum, urine and dialysis fluid.

Cl in. Nephrol. 3, 82, 1975.

MILLORA A.B., WOODRUFF M.W., KILEY J.E.

Comparison of higher blood flow hemodialysis with lower blood flow in the light of the square meter hour hypothesis.

Trans. Am. Soc. Artif. Int. Organs 18, 85, 1972.

NAKAGAWI S., SUENAGA M., SASAKI S., YOSHIYAMA N., TAKEUSHI J., KITAOKA T., KOSHIKOWA S., YAMADA T.

Comparison of dialysis programs on different molecular prescriptions : a preliminary study.

Proc. Eur. Dial. Transpl. Assoc. 14, 167, 1977.

NAKAGAWA S.

Multifactorial evaluation of hemofiltration therapy in comparison with conventional hemodialysis.

Artif. Organs 4, 94, 1980.

PIERIDES A.M*, KURTZ S.B., JDHNSON W.J.

Ultrafiltration followed by hemodialysts : a long term trial and acute studies.

J. of Dialysis $2,325,1978$.

POGGLITSCH H., HOLZER H., WALLER J., PRISTANTZ H., LEOPOLD H. , KATSCHNIGG $H$.

The cause of inadequate hemodynamic reactions during ultra- 
difusion.

Proc. Eur. Dia1. Transp1. Assoc. 15, 245, 1978.

POPOVICH R.P., HLAVINKA D.J., BOMAR J.B., MONCRIEF J.W., DECHERD J.F.

The consequences of physiological resistances on metabolite removal from the patient-artificial kidney system.

Trans. Am. Soc. Artif. Int. Organs 21, 108, 1975.

QUELLHORST E., RIEGER J., DOHT B., BECKMANN $H$, JACOB J., KRAFT

B., MIETZSCH G., SCHELER F.

Treatment of chronic uremia by an ultrafiltration kidney :

First clinical experience.

Proc. Eur. Dial. Transpl. Assoc. 13, 314, 1976.

QUELLHORST E., DOHT B., SCHUENEMANN B.

Hemofiltration : treatment of renal fallure by ultrafiltration and substitution.

J. of Dialysis 1, 529, $1977 \mathrm{~b}$.

QUELLHORST E. , SCHUENEMANN B., DOHT B.

Treatment of severe hypertension in chronic renal failure by hemofiltration.

Proc. Eur. Dial. Transp1. Assoc. 14, 129, 1977a.

QUELLHORST $E$.

Hämofiltration: Differentlalindication zur Hämodialyse unter Berïcksichtigung hämodynamischer und metabol ischer Aspekte.

Klin. Wochenschr. 57, 1061, 1979a.

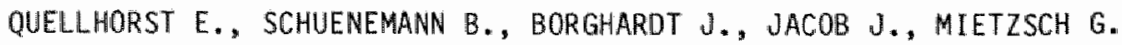
Influence of hemofiltration on blood pressure regulation.

Clin. Nephrol. 11, 150, 19796 .

QUINTON W., DILLARD D., COLE J.J., SCIBNER B.H. 
Cannulation of blood vessels for prolonged hemodialysis.

Trans. Am. Soc. Artif. Int. Argans 6, 104, 1960.

RAJA R.M., KRAMER M.S., ROSENBALM J.L.

Long term short hemodialysis : implication to dialysis index.

Trans. Am. Soc. Artif. Organs 24, 367, 1978.

ROUBY J.J., ROTTEMBOURG J., DURANDE J.P., BASSET J.Y., LEGRAIN M. Importance of the plasma refilling rate in the genesis of hypowalemic hypotension during regular dialysis and controlled sequential ultrafiltration-hemodialysis.

Proc. Eur. Dial. Transp1. Assoc. 15, 239, 1978.

SARGENT J.A., GOTCH F.A.

The study of uremia by manipulation of blood concentrations using combinations of hollow fibre devices.

Trans. Am. Soc. Artif. Int. Organs 20, 395, 1974.

SARGENT J.A., GOTCH F.A., BORAH M.

Urea kinetics : a guide to nutritional management of renal fallure.

An. J. Clin. Nutrition 31, 1696, 1978.

SAUSSE A., GRANGER A., MAN N.K., FUNCK-BRENTANO J.L.

Un nouveau rein artificiel. Nouvel appareil associant ume menbrane à haute perméabillitē et un bain de dialyse en circuit fermé.

La Nouvelle Presse Mëdicalle 3, 15, 957, 1974.

SCHAEFER K., VON HERRATH D., OFFERMANN G.

Long term experiences with chronic hemofiltration.

Int. J. Artif. Drgans 3, 219, 1980.

SCHINDHELM K. , FARRELL P.C.

Patient hemodialyzer interactions. 
Trans. Ant Soc. Artif. Int. Organs 24, 357, 1978.

SCHNEIOER H., STREICHER E., HÖVELBORN U, MULLLER H.A.G., SPOHR U., SCHM IOT-GAYK H.

Hemofiltration: critical evaluation of clinical benefits.

Proc. Eur. D1al. Transpl. Assoc. 16, $218,1979$.

SCRIBNER B.H.

Discussion.

Trans. Am. Soc. Artif. Int. Organs 11, 29, 1965.

SHALDON S., DESCHODT G., BEAU M.C., CLARET G. MION H. MION C.

Vascular stability during high flux hemofiltration (HF).

Proc. Eur. Dial. Transp1. Assoc. 16, 695, 1979.

SHALDON S.

Discussion.

Proc.Eur.Dia1.Transpl.Assoc. 18, 262, 1981.

SHALDON S., KOCH K.

Are standards and check ists needed in uremia therapy ?

In press.

SHALDON S., BALDAMUS C.A., KOCH K.M., LYSAGHT M. J.

of sodium, symptomatology and syllogism.

Blood Purification $1,16,1983$.

SHINABERGER J.H., MILLER J.H., ROSENBLATT M.G., GARDNER P.W., CARPENTER G.W., MARTIN F.E.

Clinical studies of "low flow" dialysis with membranes highly permeable to middle weight molecules.

Trans. An. Soc. Int. Organs $16,82,1972$.

SPIEGLER K.S., KEDEM 0 .

Transport coefficients and salt rejection in uncharged hyperfiltration nembranes. 
Desal ination $1,311,1966$.

SPOHR U., SCHNEIDER H., STREICHER E., SCHRACK R. "RITZ E.

Hemofiltration and plasma dopamine beta hydroxylase activity.

Nephron 25, 121, 1980.

SPRENGER $K$.

Measurement of mass transport during hemodiafiltration.

Proceedings 1 symposion hemodiafiltration Giessen 1981.

Ed. G. Schütterle e.a.

SPRENGER K., KRATZ W., LEWIS A., STADTMÜLLER U.

Kinetic modeling of hemodialysis, hemofiltration, and henodiafiltration.

Kidney Internationa $124,143,1983$.

STREICHER E., SCHNEIDER H.

Clinical experience in hemofiltration.

Int. J. Artif. Organs 3, 221, 1980.

TEEHAN B.P., GACEK E.M., HEYMACH G.J., BROWN J., SMITH L.J., SIGLER M.H., GILGORE G.S., SCHLEIFER C.R.

A clinical appraisal of the dialysis index.

Trans. Am. Soc. Artif. Int. Organs 13, 548, 1977.

TENKHOFF H., CURTIS F.K.

Experience with malntenance peritoneal dialys is in the home.

Trans. Am. Soc. Artif. Organs 16, 90, 1970.

VANTARD G.

Analyse de mode d'epuration extrarenale par hemodialyse-hemofiltration simultanëe.

Ph. D. Thesis of Biomechanics. Universite de Compiègne 1980 . VILLARROEL F., KLEIN E., HOLLAMD F.

Solute flux in hemodialysis and hemofiltration membranes. 
Trans. Am, Soc. Artif, Int. Organs 23, 225, 1977.

WEHLE $B$, ASABA H., CASTENFORS J., FURST P., GUHNARSSON B., SHALDON S., BERGSTROAN

Hemodynamic changes during sequential ultrafiltration and diaIysis.

Kioney International $15,411,1979$.

WIDERDE T.E., GRIMSUD L., BERG K.J., GOOAL A., JENSEN R., JDRSTAD \$.

A mathematical single pool model for short time hemodialysis. Proc. Eur. Dtal. Transp1. Assoc. 11, 136. 1974. 
Acknow ledgements :

- This study was performed at the Diallysis Department of the Catharina Hospital, Eindhoven.

- The indulgent participation of the patients and the dedicated assistance of the nursing staff have been invaluable for its completion.

- I am much indebted to Prof.Dr. J.A. Flendrig for the training in internal medicine he gave me, for his inspiring thoughts that initiated this work, and his stimulating participation that garanteed its progression.

- The mathematical concepts were developed by Wim Carpay. His anaHytical approach to problems often prevented me to loose the right track.

- Our outstanding technician. Wil Dekkers, designed and constructed highly sophisticated equipment. His contribution to this project has been most wital.

- Their inventive collaboration resulted in the construction of the isovalumetric pump, which they kindly permitted me to describe in chapter 11 .

- I am indebted to Prof. M.Y. Jaffrin from the University of Technology of Compiègne, and to Prof.Dr. K.H. Rahn and Dr. J.P. van Hooff from the University Hospital Annadal of Mastricht, for reviewing the manuscript.

- I gratefully acknowledge the valuable suggestions of Prof.s. Shaldon from the University Hospital of Nimes gave me in preparing the manuscript. 
- Thanks are lso due to Miss. M. Haeners for her patience in typing the manuscript.

- This work was supported by a grant from the Nierstichting NederIand. 
Jos van Geelen werd op 17 oktober 1950 geboren te 's-Hertogenbosch. In 1969 slaagde hij voor het elindexamen gymnasium B aan het St. Janslyceum aldaar. In datzelfde jaar werd de studie in de Geneeskunde aan de Rijksuniversiteit te Utrecht begonnen. In 1975 werd het artsexamen behald. Als reserve luitenant arts vervulde hij de militaire dienstplicht te Venlo. Op 1 februari 1977 begon hij de opleiding in de Inwendige Geneeskunde an het Catharinaziekenhuis te Eindhoven onder leiding van Dr. J.A. Flendrig. Het onderzoek dat leidde tot dit proefschrift werd tijdens deze opleiding verricht. Op 1 februari 1982 werd hij als Internist geregistreerd in het Specialisten Register. Na die datum bleef hij als chef de clinique werkzaam in het Catharinaziekenhuis en werd de latste hand gelegd aan dit proefschrift. Vanaf 1 oktober 1983 is hij als internist werkzaam op de Afdeling Nefrologie van het Dijkzigt Ziekenhuis te Rotterdam. 